\title{
7. SITE 499: MIDDLE AMERICA TRENCH AXIS ${ }^{1}$
}

\author{
Shipboard Scientific Party ${ }^{2}$
}

\section{HOLE 499}

Date occupied: 12 June 1979

Dáte departed: 14 June 1979

Time on hole: $64.1 \mathrm{hr}$.

Position: $12^{\circ} 40.35^{\prime} \mathrm{N}$; $90^{\circ} 56.65^{\prime} \mathrm{W}$

Water depth (sea level; corrected $\mathrm{m}$, echo sounding): 6105

Water depth (rig floor; corrected $\mathrm{m}$, echo sounding): 6115

Bottom felt (m, drill pipe): 6126.5

Penetration (m): 229.0

Number of cores: 25

Total length of cored section $(\mathrm{m}): 229.0$

Total core recovered $(\mathrm{m}): 118.9$

Core recovery $(\%): 51.9$

Oldest sediment cored:

Depth sub-bottom (m): 229.0

Nature: Calcareous ooze

Age: Late early Miocene

Basement: Not reached

Principal results: A pelagic sedimentary section was encountered beneath a wedge of trench-filling turbidites.

\section{HOLE 499A}

Date occupied: 14 June 1979

Date departed: 16 June 1979

Time on hole: $25.4 \mathrm{hr}$.

Position: $12^{\circ} 40.65^{\prime} \mathrm{N}$; $90^{\circ} 56.78^{\prime} \mathrm{W}$

Water depth (sea level; corrected $\mathbf{m}$, echo sounding): 6108

Water depth (rig floor; corrected $\mathbf{m}$, echo sounding): 6118

Bottom felt (m, drill pipe): 6132

\footnotetext{
${ }^{I}$ Aubouin, J., von Huene, R., et al., Inir. Repts. DSDP, 67: Washington (U.S. Govt. Printing Office).

2 Roland von Huene (Co-Chief Scientist), U.S. Geological Survey, Menlo Park, California; Jean Aubouin (Co-Chief Scientist), Département de Géologie Structurale, Université Pierre et Maric Curie, Paris, France; Jacques Azéma, Departement de Géologie Structurale, Université Pierre et Marie Curie, Paris, France; Grant Blackinton, Hawaii Institute of Geophysics, University of Hawaii, Honolulu, Hawaii; Jerry A. Carter, Hawaii Institute of Geophysics, University of Hawaii, Honolulu, Hawaii; William T. Coulbourn, Deep Sea Drillin Project, Scripps Institution of Oceanography, La Jolla, California; Darrel S. Cowan, Department of Geological Sciences, University of Washington, Seatle. Whingon, Joseph A. ment of Geopica Scies, Units dress: Union Oil Compar dress: Union Oil Company of California, P.O. Box 76, Brea, Ca.); Carlos A. Dengo, Depar ment of Geology and Center for Tectonsphysics, Texas A\&M University, College Station, Texas; Richard W. Faas, Department of Geology, Lafayette College, Easton, Pennsylvania; William Harrison, Department of Geology, University of Oklahoma, Norman, Oklahoma; Reinhard Hesse, Lehrstuhl für Geologie, Technische Universität, Münich, Federal Republic of Germany, and Department of Geological Sciences, McGill University, Montreal, Quebec, Canada: Donald M. Hussong. Hawaii Institute of Geophysics. University of Hawail, Honolulu, Hawaii; John W. Ladd, The Univesity of Texas, Marine Sciece Insicte. York); Nikita Muzylöv, Geological Institute, U.S.S.R. Academy of Sciences, Moscow, U.S.S.R: Tsunemasa Shiki, Department of Geology and Mineralogy, Faculty of Science. Kyoto University, Kyoto, Japan; Peter R. Thompson, Lamont-Doherty Geological Obser vatory, Palisades, New York; and Jean Westberg, Geological Research Division, Scripps In stitution of Oceanography, La Jolla, California.
}

Penetration (m): 43

Number of cores: 5

Total length of cored section (m): 43

Total core recovered $(\mathrm{m}): 12.59$

Core recovery $(\%): 29.2$

Oldest sediment cored:

Depth sub-bottom (m): 43

Nature: Mudstone

Age: Quaternary

Basement: Not reached

Principal results: A comparison with Hole 499 indicates no lateral facies change in trench-filling turbidities.

\section{HOLE 499B}

Date occupied: 15 June 1979

Date departed: 17 June 1979

Time on hole: $40 \mathrm{hr}$.

Position: $12^{\circ} 40.23^{\prime} \mathrm{N} ; 90^{\circ} 56.68^{\prime} \mathrm{W}$

Water depth (sea level; corrected m, echo sounding): 6105

Water depth (rig floor; corrected $\mathrm{m}$, echo sounding): 6115

Bottom felt (m, drill pipe): 6126.5

Penetration (m): 286.5

Number of cores: 10

Total length of cored section $(\mathrm{m}): 85.5$

Total core recovered $(\mathrm{m}): 21.35$

Core recovery $(\%): 24.9$

Oldest sediment cored:

Depth sub-bottom (m): 268

Nature: Chalk

Age: Early Miocene

Measured velocity $(\mathrm{km} / \mathrm{s}): 1.6-1.8$

Basement:

Depth sub-bottom (m): 285

Nature: Basalt

Velocity range $(\mathrm{km} / \mathrm{s}): 5.6$

Principal results: Portions of the stratigraphic section drilled at Hole 499 were repeated; we encountered weathered basalt at 285 meters sub-bottom depth.

\section{HOLE 499C}

Date occupied: 17 June 1979

Date departed: 18 June 1979

Time on hole: $25.6 \mathrm{hr}$.

Position: $12^{\circ} 40.30^{\prime} \mathrm{N}$; $90^{\circ} 57.03^{\prime} \mathrm{W}$

Water depth (sea level; corrected m, echo sounding): 6102

Water depth (rig floor; corrected $\mathbf{m}$, echo sounding): 6112

Bottom felt (m, drill pipe): 6112 
Penetration (m): 263

Number of cores: 1

Total length of cored section $(\mathrm{m}): 3$

Total core recovered $(\mathrm{m}): 0.3$

Core recovery $(\%): 10$

Oldest sediment cored: None

Basement:

Depth sub-bottom (m): 260

Nature: Basalt

Velocity range $(\mathrm{km} / \mathrm{s}): 5.6$

Principal results: We recovered weathered basalt at 260 meters subbottom depth.

\section{HOLE 499D}

Date occupied: 23 June 1979

Date departed: 25 June 1979

Time on hole: $36.3 \mathrm{hr}$.

Position: $12^{\circ} 40.45^{\prime} \mathrm{N}$; $90^{\circ} 56.70^{\prime} \mathrm{W}$

Water depth (sea level; corrected m, echo sounding): 6116

Water depth (rig floor; corrected m, echo sounding): 6126

Bottom felt (m, drill pipe): 6126

Penetration (m): 216

Number of cores: 1

Total length of cored section (m): 3.5

Total core recovered $(\mathrm{m}): 0.75$

Core recovery $(\%): 21$

Oldest sediment cored: Not available

Basement:

Depth sub-bottom (m): 213

Principal results: We encountered weathered basalt at a sub-bottom depth of 213 meters, about 60 meters shallower than the level at which rock was encountered in Holes 499B and 499C.

Principal results (Holes 499-499D): Site 499 includes five holes drilled on the trench floor (Figs. 1 and 2). Seismic-reflection records show a sequence of horizontal reflections, presumed to be trench fill, underlain by a sequence of reflections with a gentle landward dip, perhaps representative of the deep-ocean sedimentary section. Hole 499 was drilled just seaward of the trench axis (Fig. 2) and consisted of 201 meters of terrigenous mud overlying nannofossil chalk. Subsequently, the bottom of an axial depression was drilled at 499A to define lateral facies changes in the trench fill. Hole 499 was paralleled at $499 \mathrm{~B}$, which was drilled to a rubbly basalt. Because basalt cobbles from Hole 499B were altered and rounded and not a convincing indication of basement, another hole (499C), offset $1,000 \mathrm{ft}$. along strike, was washed to basement. Once again, rounded and altered basalt cobbles were cored. Hole 499D was washed to 216 meters for the purpose of logging, and a rubbly conglomerate was encountered about 50 meters above the seismic basement objective.

The lithologic sequence at Site 499 is the same as at Site $\mathbf{4 9 5}$, the oceanic reference site, but with the addition of a cover trenchfill turbidite. The turbidites, 117 meters thick, are predominantly muddy, although sandy layers may have been penetrated in intervals of poor recovery. About $1 \mathrm{~km}$ away, at Hole 499A, similar turbidite units appear in a channel indicating that the axial fill of the Middle America Trench is uniform at this location. At Site 499 the turbidites end abruptly and are underlain by burrow-mottled hemipelagic mud, calcareous ooze and chalk, and finally basalt rubble. The calcareous section is about one-third as thick as that at Site 495 .

Microfossils occur in the same succession as at Site 495 with the addition of the Quaternary trench-fill sequence. The trench fill has abundant reworked and transported calcareous microfossils, and the 400,000-yr. radiolarian zonal marker clearly exists below the trench fill. Within the calcareous section, there is more dissolution of foraminifers than at Site 495, indicating deposition nearer the CCD. The oldest sediment was deposited in the earliest Miocene, as at Site 495 .

In addition to lithology and biogenic constituents, the measured physical properties and gaseous hydrocarbons change downhole between the trench fill and the underlying deep-ocean section.

\section{BACKGROUND AND OBJECTIVES}

Site 499 is in the Middle America Trench axis off Guatemala, about $1 \mathrm{~km}$ from the seaward slope and in 6126 meters of water. This site was originally planned as an alternate if Hole 495 was not drilled; however, it was drilled in order to allow time for decisions on shore regarding further drilling at Site 494.

Both the multichannel reflection profiles GUA-13 and 18 and the single-channel records made from the Challenger show an upper horizontal reflective sequence underlain by a landward dipping sequence. Site 499 was positioned so that both sequences would be sampled, but not where they are thickest. At Site 499 we anticipated drilling ponded trench fill, an underlying sequence of hemipelagic sediment, calcareous ooze, and finally basalt analogous to the section at Site 495 .

Our objective was to date the trench fill in order to provide an estimate of the maximum residence time a sêgment of ocean crust is in the trench axis. Considering the approximate $2.8-\mathrm{km}$ width of the trench fill, if the ocean crust is converging with the continental crust at a rate of $9 \mathrm{~cm} / \mathrm{yr}$., the residence time of a segment of ocean crust under the trench fill should be about $320,000 \mathrm{yr}$. That time span is probably too short to be defined by biostratigraphic or paleomagnetic methods, however, we do not know if the maximum age of the trench fill was greater than $320,000 \mathrm{yr}$.

\section{OPERATIONS}

Glomar Challenger departed Site 498 on June 10, 1518L (Local Time), bound for Acajutla, El Salvador, to make an emergency call and pick up chemicals needed in the engine room. On June 11 the ship anchored outside the harbor and departed $7 \mathrm{hr}$. later enroute to Site 494. A message received from the Deep Sea Drilling Project ordered drilling at Site 499 instead.

Glomar Challenger crossed the 494 beacon and followed the GUA-13 and 18 seismic lines, passing over Site 499. The beacon to be deployed failed before launching, therefore no beacon was dropped during the first pass. On a return track, a new beacon was dropped and the Challenger was in position on the site on June 12, 0420L.

The first core was recovered at Site 499 on June 12 $1852 \mathrm{~L}$ (Table 1). Shortly thereafter a second message from DSDP requested immediate drilling at Site 494 to avoid simultaneous drilling and recovery of the HIG data package. The string was pulled above the mudline prior to reaching basalt. A short hole at 499A was drilled to test lateral facies variability in the trench fill, and then the drill pipe was brought on board. Still another message from DSDP arrived when the ship was depart- 


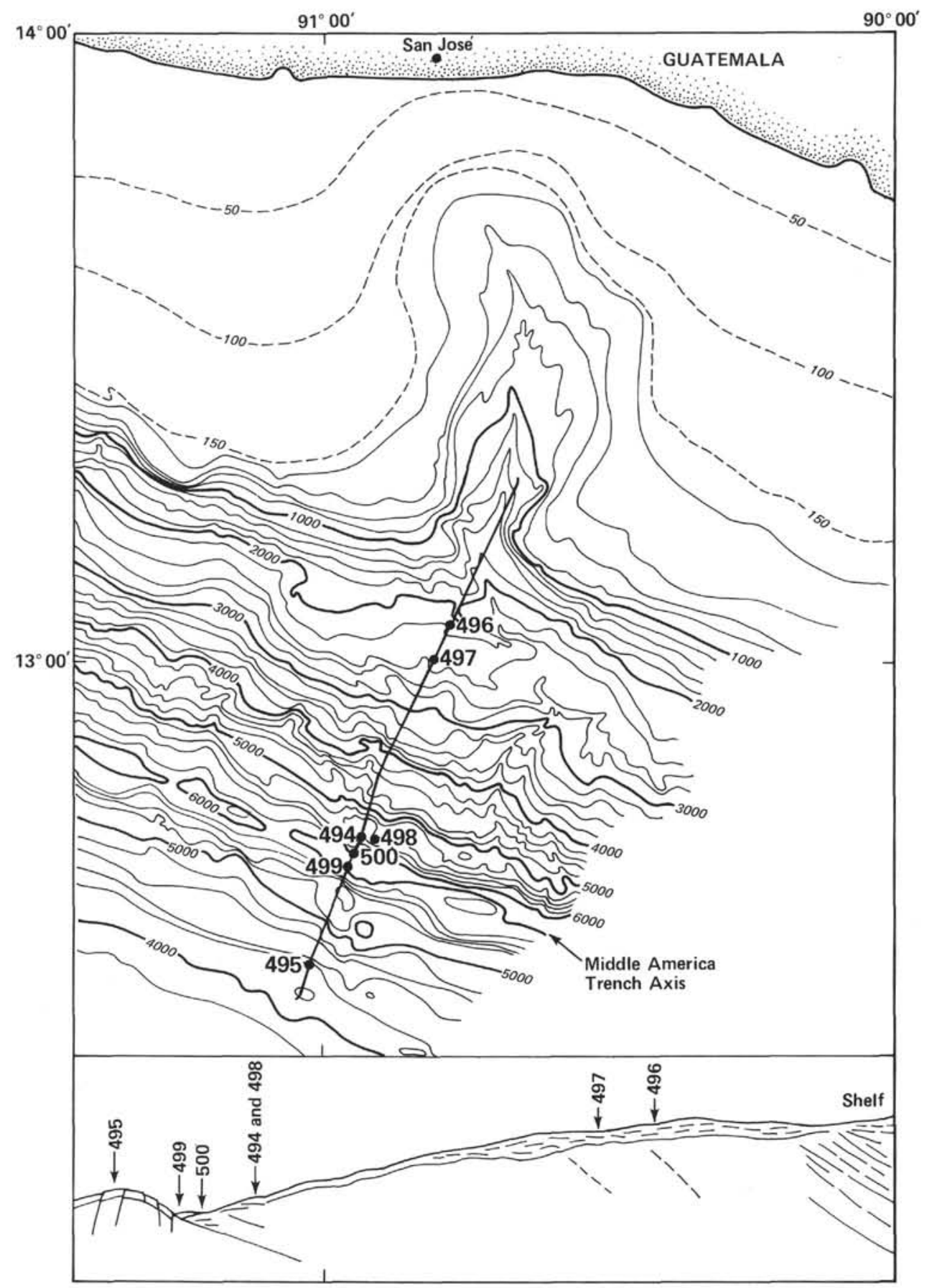

Figure 1. Location map for Site 499.

ing for Site 494. The Project disallowed drilling at Site 494 during retrieval of the HIG data package. Thus the drill string was again lowered and Hole 499B was drilled to basalt. The calcareous section was much thinner than at 495 and the basalt appeared to be from a rubble zone. Hole 499C, an offset along strike $1000 \mathrm{ft}$. from 499B, was washed down to recore the lower chalk and basalt. During wash down a hard layer was intercepted prior to lower chalk depth at Hole 499B. A 3-meter core brought up more basalt rubble with some drill-cut pieces. Following drilling operations at Site 500, Hole 499D was washed to an unexpectedly shallow rubble horizon at a sub-bottom depth of 213 meters.

\section{LITHOSTRATIGRAPHY}

At Site 499, five holes were drilled (499, 499A, 499B, 499C, and 499D) at water depths between 6112 and 6132 meters on the floor of the Middle America Trench off Guatemala. Site 499 is located approximately $20 \mathrm{~km}$ NNE (north-northeast) of Site 495, the Leg 67 oceanic reference site for pelagic and hemipelagic sediment of the Cocos Plate. The surface of the horizontal trench fill 


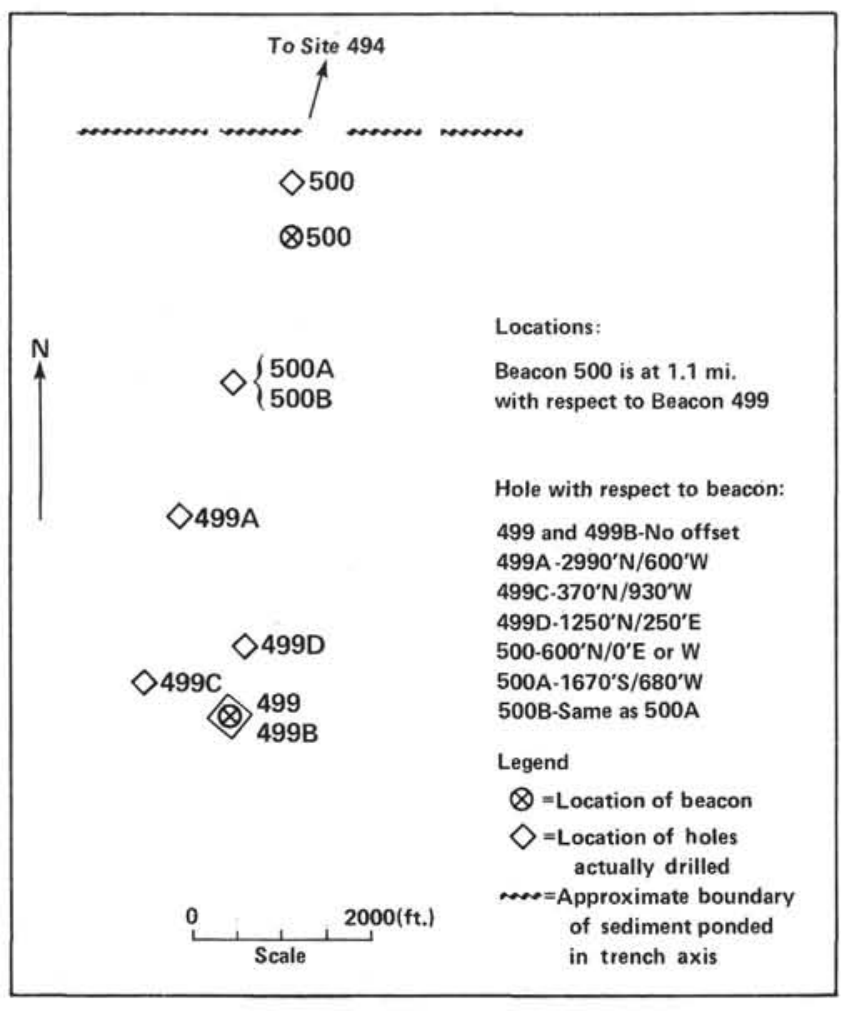

Figure 2. Detail of Middle America Trench axis showing relative positions of the eight holes drilled at Sites 499 and 500. (Holes 499 and 499B were drilled at the Site 499 beacon.)

is approximately $2.3 \mathrm{~km}$ wide at this locality. Hole 499 was placed at a slightly elevated position on the trench floor, approximately $1 \mathrm{~km}$ from the seaward slope rather than in the trench axis, to avoid possible poor core recovery should the somewhat deeper central portion represent a channel filled with coarse sediment. After drilling to the calcareous section in Hole 499, a second hole (499A) was drilled in the trench axis. Because plans to drill an additional hole at Site 494 were abandoned, it was possible for the Challenger to reoccupy Site 499 and attempt to penetrate oceanic basement under the trench floor. When the drill string stuck in Hole 499B short of this objective, a fourth hole (499C) offset along strike was drilled. A fifth hole was drilled for the purpose of logging (499D).

At Site 499 six lithologic units were distinguished; the uppermost is composed of terrigenous trench fill and the lowermost of basalt (Fig. 3). The four units between consist of hemipelagic and pelagic sediments that represent lateral equivalents of the oceanic sequence encountered at Site 495 .

Unit 1 (Hole 499, Cores 1 to 14, Section 2, $42 \mathrm{~cm}$, 0-117.0 m sub-bottom depth; Hole 499A, Cores 1 to 5, 0-43.0 m sub-bottom depth; Quaternary)

The sediment of Unit 1 is an alternate muddy and sandy upper Pleistocene to Holocene trench fill. Dark olive gray $(5 Y 3 / 2)$ or very dark olive gray $(5 Y 2.5 / 2)$ to greenish olive gray $(5 G Y 4 / 1)$ diatomaceous, partly nannofossil- and/or ash-bearing muds, terrigenous and vol- canogenic sand layers, and a few distinct ash layers (which are restricted to Cores 1 and 13) compose Unit 1 sediments.

The first distinct turbidite is in Core 3-a relatively light olive gray (5Y 4/2), nannofossil-rich mud layer that grades downward into laminated sandy mud. The latter occurs in Section 4 of Core 3, but it was not clear whether this turbidite includes the entire 4.0-meter-thick mud layer of Sections 2 and 3 as well as the upper half of Section 4 overlying the olive gray mud. In general, distinguishing turbidite muds from hemipelagic muds is difficult without the use of a specific X-radiography technique (e.g., Hesse, 1977), but in cores severely disturbed by drilling it may be impossible. Turbidite sands of Unit 1 are as badly affected by drilling disturbance as are the muds and rarely display primary sedimentary structures other than deformed laminations. Often the sand layers are broken into patches, swirls, and blobs (e.g., Core 6, Section 3). Even where grading was observed in thick, coarse, sand layers (e.g., Core 6, Section 4; Core 7, Section 4; Core 9, Section 1; Core 11, Section 1), it might have been produced by drilling, as shown by the graded drilling breccia recovered at Site 498 (Core 2, Section 1 and Core 4, Section 1). The maximum thickness of recovered turbidite sands in Hole 499 is $110 \mathrm{~cm}$ (e.g., Core 6, Section 4, Core 11, Section 1). The maximum grain size at the base of some of these layers is coarse sand. The sand to mud layer thickness ratio may not be meaningful for there is probably a minimum amount of sand recovered in Unit 1. Cores with no recovery (i.e., Cores 4 and 8 in Unit 1) may have been unconsolidated sand.

The sediment composing the trench fill includes a spectrum of microfossils and fossil fragments ranging from terrestrial plants (Cores 1-10) to shallow marine benthic foraminifers (Cores 1-5), echinoid spines, upper bathyal foraminifers (Cores 1-10), and lower bathyal abyssal foraminifers, which indicate redeposition (see the section on Biostratigraphy). Some of the redeposited muds, particularly lighter olive gray varieties, contain up to $30 \%$ calcareous nannofossils that must be allochthonous, because water depth of the trench floor is well below the calcite compensation level. The occurrence of limestone pebbles with lower Miocene nannofossils in the sand turbidite of Core 9, Section 1 also indicates redeposition of sediment from higher up on the slope.

Terrigenous volcanogenic sediment is abundant in the trench-fill sediment. The sand and silt-sized fractions are glass, feldspar, (quartz?), and a suite of heavy minerals (usually hypersthene, augite, epidote, titanium hornblende, etc.) that can be related to the Neogene volcanic rocks of Guatemala.

Paucity of bioturbation in the muds of Unit 1 as compared to Units 2 to 4 suggests that these may be dominantly turbiditic in origin.

In Cores 1 to 5 of Hole 499A (located about $1 \mathrm{~km}$ landward from Hole 499), a lithologic sequence nearly matches that of Hole 499. With better-quality cores, a layer-to-layer matching might have been achieved. The lack of substantially coarser sediments in Hole 499A suggests that the slight axial depression of the trench 
Table 1. Coring summary for Holes 499, 499A, 499B, 499C, and 499D.

\begin{tabular}{|c|c|c|c|c|c|c|c|}
\hline Core No. & $\begin{array}{c}\text { Date } \\
\text { (June, 1979) }\end{array}$ & $\begin{array}{l}\text { Local Time } \\
\text { (L) }\end{array}$ & $\begin{array}{l}\text { Depth from } \\
\text { Drill Floor } \\
\text { (m; top-bottom) }\end{array}$ & $\begin{array}{c}\text { Sub-bottom } \\
\text { Depth } \\
\text { (m; top-bottom) }\end{array}$ & $\begin{array}{l}\text { Length } \\
\text { Cored } \\
\text { (m) }\end{array}$ & $\begin{array}{l}\text { Length } \\
\text { Recovered } \\
\text { (m) }\end{array}$ & $\begin{array}{c}\text { Recovery } \\
(\%)\end{array}$ \\
\hline \multicolumn{8}{|l|}{ Hole 499} \\
\hline 1 & 12 & 1852 & $6126.5-6127.5$ & $0.0-1.0$ & 1.0 & 0.73 & 73 \\
\hline 2 & 12 & 2041 & $6127.5-6137.0$ & $1.0-10.5$ & 9.5 & 9.99 & 100 \\
\hline 3 & 12 & 2215 & $6137.0-6146.5$ & $10.5-20.0$ & 9.5 & 6.00 & 63 \\
\hline 4 & 13 & 0353 & $6146.5-6156.0$ & $20.0-29.5$ & 9.5 & 0.0 & 0 \\
\hline 5 & 13 & 0529 & $6156.0-6165.5$ & $29.5-39.0$ & 9.5 & 8.00 & 84 \\
\hline 6 & 13 & 0706 & $6165.5-6175.0$ & $39.0-48.5$ & 9.5 & 5.84 & 61 \\
\hline 7 & 13 & 0838 & $6175.0-6184.5$ & $48.5-58.0$ & 9.5 & 8.32 & 88 \\
\hline 8 & 13 & 1020 & $6184.5-6194.0$ & $58.0-67.5$ & 9.5 & 0.0 & 0 \\
\hline 9 & 13 & 1205 & $6194.0-6203.5$ & $67.5-77.0$ & 9.5 & 1.21 & 13 \\
\hline 10 & 13 & 1406 & $6203.5-6213.0$ & $77.0-86.5$ & 9.5 & 6.08 & 64 \\
\hline iI & 13 & 1558 & $6213.0-6222.5$ & $86.5-96.0$ & 9.5 & 3.86 & 41 \\
\hline 12 & 13 & 1741 & $6222.5-6232.0$ & $96.0-105.5$ & 9.5 & 3.70 & 39 \\
\hline 13 & 13 & 1936 & $6232.0-6241.5$ & $105.5-115.0$ & 9.5 & 7.24 & 76 \\
\hline 14 & 13 & 2132 & $6241.5-6251.0$ & $115.0-124.5$ & 9.5 & 3.87 & 41 \\
\hline is & 13 & 2320 & $6251.0-6260.5$ & $124.5-134.0$ & 9.5 & 4.93 & 52 \\
\hline 16 & 14 & 0101 & $6260.5-6270.0$ & $134.0-143.5$ & 9.5 & 0.45 & 5 \\
\hline 17 & 14 & 0243 & $6270.0-6279.5$ & $143.5-153.0$ & 9.5 & 6.60 & 64 \\
\hline 18 & 14 & 0415 & $6279.5-6289.0$ & $153.0-162.5$ & 9.5 & 8.74 & 92 \\
\hline 19 & 14 & 0550 & $6289.0-6298.5$ & $162.5-172.0$ & 9.5 & 8.52 & 90 \\
\hline 20 & 14 & 0731 & $6298.5-6308.0$ & $172.0-181.5$ & 9.5 & 0.0 & 0 \\
\hline 21 & 14 & 0921 & $6308.0-6317.5$ & $181.5-191.0$ & 9.5 & 0.38 & 4 \\
\hline 22 & 14 & 1110 & $6317.5-6327.0$ & $191.0-200.5$ & 9.5 & 9.31 & 98 \\
\hline 23 & 14 & 1312 & $6327.0-6336.5$ & $200.5-210.0$ & 9.5 & 5.68 & 60 \\
\hline 24 & 14 & 1459 & $6336.5-6346.0$ & $210.0-219.5$ & 9.5 & 4.62 & 49 \\
\hline 25 & 14 & 1657 & $6346.0-6355.5$ & $219.5-229.0$ & 9.5 & 4.92 & 52 \\
\hline \multicolumn{8}{|l|}{ Hole 499A } \\
\hline 1 & 15 & 0047 & $6132.0-6137.0$ & $0.0-5.0$ & 5.0 & 2.92 & 58 \\
\hline 2 & is & 0238 & $6137.0-6146.5$ & $5.0-14.5$ & 9.5 & 2.83 & 30 \\
\hline 3 & is & 0417 & $6146.5-6156.0$ & $14.5-24.0$ & 9.5 & 5.35 & 56 \\
\hline 4 & is & 0552 & $6156.0-6165.5$ & $24.0-33.5$ & 9.5 & 0.0 & 0 \\
\hline 5 & 15 & 0719 & $6165.5-6175.0$ & $33.5-43.0$ & 9.5 & 1.49 & 16 \\
\hline \multicolumn{8}{|l|}{ Hole 499B } \\
\hline 1 & 16 & 1653 & $6327.0-6337.0$ & $201.0-210.5$ & 9.5 & 0.14 & 1 \\
\hline 2 & 16 & 1830 & $6337.0-6346.5$ & $210.5-220.0$ & 9.5 & 2.30 & 24 \\
\hline 3 & 16 & 2017 & $6346.5-6356.0$ & $220.0-229.5$ & 9.5 & 6.91 & 73 \\
\hline 4 & 16 & 2206 & $6356.0-6365.5$ & $229.5-239.0$ & 9.5 & 4.25 & 45 \\
\hline 5 & 16 & 2354 & $5365.5-6375.0$ & $239.0-248.5$ & 9.5 & 0.30 & 3 \\
\hline 6 & 17 & 0132 & $6375.0-6384.5$ & $248.5-258,0$ & 9.5 & 1.22 & 13 \\
\hline 7 & 17 & 0332 & $6384.5-6394.0$ & $258.0-267.5$ & 9.5 & 0.05 & $>1$ \\
\hline 8 & 17 & 0516 & $6394.0-6403.5$ & $267.5-277.0$ & 9.5 & 5.23 & s5 \\
\hline 9 & 17 & 0802 & $6403.5-6412.0$ & $277.0-285.5$ & 8.5 & 0.55 & 6 \\
\hline 10 & 17 & 0930 & $6412.0-6413.0$ & $285.5-286.5$ & 1.0 & $0.4 C$ & 40 \\
\hline \multicolumn{8}{|l|}{ Hole $499 \mathrm{C}$} \\
\hline 1 & 17 & 2132 & $6372.0-6375.0$ & $260.0-263.0$ & 3.0 & 0.30 & 10 \\
\hline \multicolumn{8}{|l|}{ Hole 499D } \\
\hline 1 & 24 & 0115 & $6338.5-6342.0$ & $212.5-216,0$ & 3.5 & 10 & 28 \\
\hline
\end{tabular}

floor at Hole 499A (6 $\mathrm{m}$ deeper than marginal portions) does not represent a channel. Currents in a channel might have differentiated coarse channel-fill and finer spill-over facies on a levee. Because the trench floor is relatively narrow at this locality, it may serve as a "channel" itself, the entire width representing a channel floor without discernible levees.

Unit 2 (Hole 499, Core 14, Section 2, $42 \mathrm{~cm}$ to Core 23, Section 1, $30 \mathrm{~cm}, 117.0-201.0 \mathrm{~m}$ sub-bottom depth; lower Pleistocene to upper Pliocene)

Turbidite deposition disappears abruptly in Hole 499 below Core 14, Section $2,42 \mathrm{~cm}$, suggesting that the boundary between the trench fill (Unit 1) and the underlying sediments is sharp. The latter comprise an 84.0meter-thick sequence of hemipelagic dark olive gray (5Y $3 / 2$ to rarely $5 \mathrm{Y} 2 / 1)$ or dark greenish gray $(5 \mathrm{GY} 4 / 1)$ diatomaceous mud. Volcanic glass is abundant. In Core 18 , a fibrous authigenic carbonate produces a lightercolored calcareous mud. The absence of biogenic $\mathrm{CaCO}_{3}$ in the lower half of Unit 2 is noteworthy. Bioturbation is the outstanding structural feature of these sediments.

The occurrence of basalt cobbles at the top of Core 15 might be related to the occurrence of a fault scarp ex- posing basalt at the time when the oceanic crust approached the trench region.

Unit 3 (Hole 499, Core 23, Section 1, 30-83 cm, 201.0-201.5 m sub-bottom depth; lower Pliocene to upper Miocene)

Unit 3 consists of only $50 \mathrm{~cm}$ of the bioturbated, siliceous mud resembling that encountered in Unit 2 except for the addition of dark reddish gray colors (10R 3/1) occurring as bioturbated laminae, patches, or lumps. This thin unit covers a time span of $12 \mathrm{~m} . \mathrm{y}$., signaling extremely low sedimentation rates. The unit probably corresponds to the brown abyssal clay found in Unit 2 of Site 495 .

Unit 4 (Hole 499, Core 23, Section 1, lower half, to Core 25, 201.5-229.0 m sub-bottom depth; Hole 499B, Cores 1 to 8, Section 3, 201.0$272.0 \mathrm{~m}$ sub-bottom depth; upper Miocene)

Nannofossil ooze and chalk of Unit 4 follow and are in sharp contact with Unit 3 . The contact is well displayed in Hole 499, Core 23, Section 1 by the pronounced color contrast between the dark sediments of Unit 3 and the light-colored calcareous sediments of Unit 4 . The 


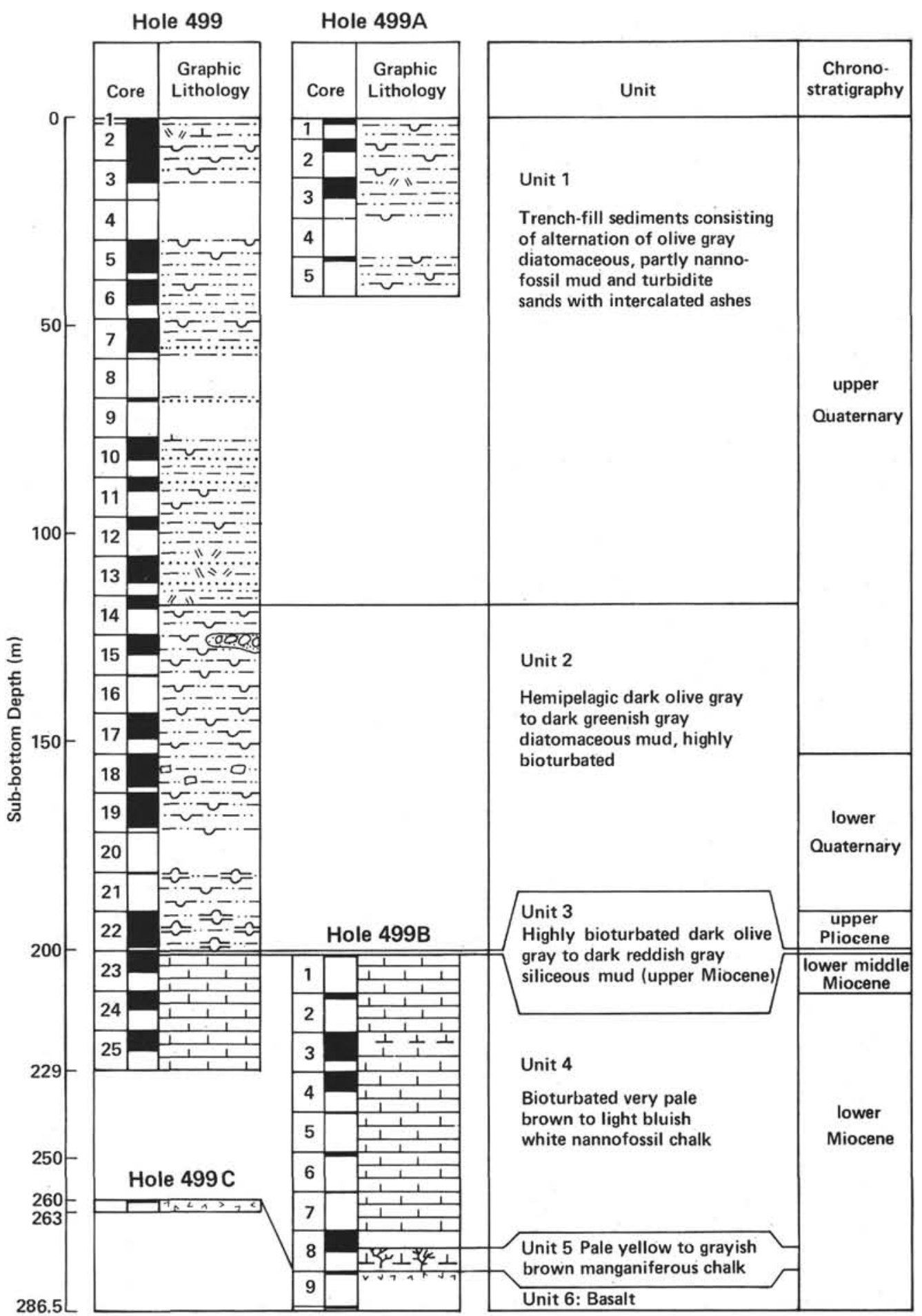

Figure 3. Summary lithologic column for Site 499. (Symbols follow DSDP format.)

boundary was also encountered in the core catcher of Core 1, Hole 499B, although there the sediment was disturbed by drilling. Colors in the nannofossil and foraminiferal chalk vary from very pale brown (10YR $7 / 3)$, brownish white (10YR 8/4), light brownish gray (10YR $6 / 2)$ to very light orange (10YR $8 / 3$ ) or pinkish white $(5$ YR $8 / 2)$ at the top (Cores 1 to 3 , Hole $499 \mathrm{~B}$ ), to a dominant light bluish white (5B 8/1) in Cores 4 to 6 . Starting with Core 7 light yellow white $(5 \mathrm{Y} 8 / 1)$ colors reappear, which in Core 8 change to brownish hues. Thus the downhole color variation in the pelagic chalks of Holes 499 and 499B is very similar to the one observed in the upper and lower sub-units of Unit 3, Site 495. No radiolarians were found below Core 7 , Hole 
499B. The chalk at Site 499 is 70.0 meters thick, less than a third as thick as the $\mathbf{2 3 5}$ meters at Site 495 . All sediments of Unit 4 are highly bioturbated.

Unit 5 (Hole 499B, Core 8, Section 3, $100 \mathrm{~cm}$, to Core 9, 272.0-280.0 m sub-bottom depth; lower Miocene)

Six meters of pale yellow $(5 \mathrm{Y} 8 / 3)$ and white $(2.5 \mathrm{Y}$ $8 / 2$ ) to grayish brown (10YR $5 / 2)$ manganiferous chalk compose Unit 5. Manganese minerals occur in the form of dark dendrites. The sediment is highly bioturbated.

Unit 6 consists of basalt (see the following section on Igneous Petrology).

\section{Igneous Petrology}

One fragment of basalt was recovered in the core catcher of Core 9 (Hole 499B), and both Core 10 from Hole 499B and Core 1 from Hole 499C contained several pieces of basalt. Most pieces are dark gray, medium-grained, phyric basalt containing up to $20 \%$ dark gray to yellow white clusters of plagioclase phenocrysts up to $5 \mathrm{~mm}$ in diameter. A few pieces contain $5 \%$ or less of 1- to 3-mm olivine(?) phenocrysts that have been completely altered to a soft, dark brown clay. Several pieces in Core 1 (499C) have color variations suggestive of weathered exteriors. Pieces 7 and 8 in this core are subrounded and smooth and have yellowish gray exteriors. Well-developed weathering rinds enclose darker gray cores. These pieces are aphyric and aphanitic and contain abundant disseminated pyrite grains.

Six thin sections from these cores were studied. The basalts typically have subophitic to intergranular, diabasic textures, and the groundmass consists of about $25 \%$ to $30 \%$ colorless to very pale brown clinopyroxene augite and $70 \%$ zoned plagioclase laths averaging 0.5 $\mathrm{mm}$ in length. Samples are coarser-grained and distinctly more porphyritic than those recovered at Site 495. Plagioclase phenocrysts up to $2 \mathrm{~mm}$ long are generally clustered and display oscillatory zoning. Piece 8 in Core 1 $(499 \mathrm{C})$ is finer grained and has intergranular texture; plagioclase microlites are 0.1 to $0.2 \mathrm{~mm}$ long.

The alteration mineralogy is unusual for oceanic ridge basalts in general. Each sample studied petrographically contains fine-grained, fibrous to prismatic, pale green amphibole tentatively identified as actinolite. The amphibole has partially replaced clinopyroxene, but in all but one thin section it is distributed in patches or localized in tiny veinlets. In Piece 1 of Core 1 (499C), nearly all of the augite has been replaced. Some preliminary optical data were obtained: $2 \mathrm{~V}(-)>70^{\circ}$; positive elongation; $\mathrm{z} \wedge \mathrm{c}$ averages $16^{\circ}$ but some extinction angles as large as $21^{\circ}$ were noted; pleochroism $\mathrm{Z}=$ green, $\mathrm{X}=$ very pale green, $\mathrm{Y}=$ very pale yellowish green. Several sections also contain a very pale green, limpid intersertal mineral with low birefringence tentatively interpreted to be chlorite. All sections contain murky, greenish brown intersertal clay, which might have replaced clinopyroxene or possibly primary glass. Very rare relict olivine phenocrysts are totally replaced by brown clay and also, in Piece 6 in Core 10 (499B), by very fine-grained aggregates of a highly birefringent mineral that may be talc. Small disseminated pyrite grains constitute $2 \%$ to $5 \%$ of all samples studied. Neither chlorite nor actinolite were noted in basalts from Site 495, which instead contain clay minerals, zeolite, and calcite.

The actinolite and chlorite(?) in these samples are evidence of a high-temperature, probably hydrothermal, alteration that was induced at or near a spreading center. "Hydrothermal" actinolite was also noted in some basalts recovered on Leg 65 in the Gulf of California. Most oceanic basalts, however, are characterized by the alteration mineralogy encountered at Site 495, which forms during cold seawater-rock interactions. Samples from Site 499 also show the effects of submarine weathering, and even though their primary mineralogy is typical of oceanic basalts and diabases, the fragments might have accumulated in talus originating from submarine scarps exposing basaltic crust.

\section{PHYSICAL PROPERTIES}

\section{Bulk Density and Water Content}

Both parameters are sensitive to lithologic variation at Site 499. Three distinctly different units can be seen (Fig. 4A).

Unit 1 extends from the mud line down to 140 meters. Bulk density increases gradually through the first $50 \mathrm{me}$ ters to about $1.55 \mathrm{Mg} / \mathrm{m}^{3}$ and shows considerable variability, perhaps attributable to alternating coarse- and fine-grained turbidite sediments. Water content decreases as expected to 90 meters and remains essentially constant at $80 \%$ to 140 meters.

Unit 2 extends from 140 meters down to 225 meters. Bulk density remains unusually constant at about 1.48 $\mathrm{Mg} / \mathrm{m}^{3}$. On the other hand, water content increases to values in excess of $100 \%$ (dry weight) and shows considerable variability. Intermittent lenses and layers of volcanic ash, interbedded with siliceous hemipelagic oozes occur through this unit and give it its water-rich character. Toward the base of the unit, bulk density increases significantly with the addition of a highly siliceous component.

Unit 3. Sampling above and below the contact with the white calcareous nannofossil chalk indicates sharp differences in water content $(130 \%$ vs. $75 \%)$ and bulk density (from $1.47 \mathrm{Mg} / \mathrm{m}^{3} \mathrm{vs} .1 .70 \mathrm{Mg} / \mathrm{m}^{3}$ ).

Figure 4B shows bulk density and water content for Hole 499A. They correspond with the values for Unit 1 (Hole 499), as expected.

Figure $4 \mathrm{C}$ shows bulk density and water content for Hole 499B. Cores 2 and 3 have bulk densities and water contents similar to Unit 3 of Hole 499 (Figs. 4A and 3) and characterize the physical properties of the Miocene chalk. There is a general increase in bulk density and decrease in water content approaching the basalt.

\section{Compressional-Wave Velocity}

\section{Hole 499B}

Figure 5 shows the compressional-wave velocity profile with depth in the Miocene chalks of Hole 499B. Velocities varied between 1.58 to $1.84 \mathrm{~km} / \mathrm{s}$, increasing to 
A

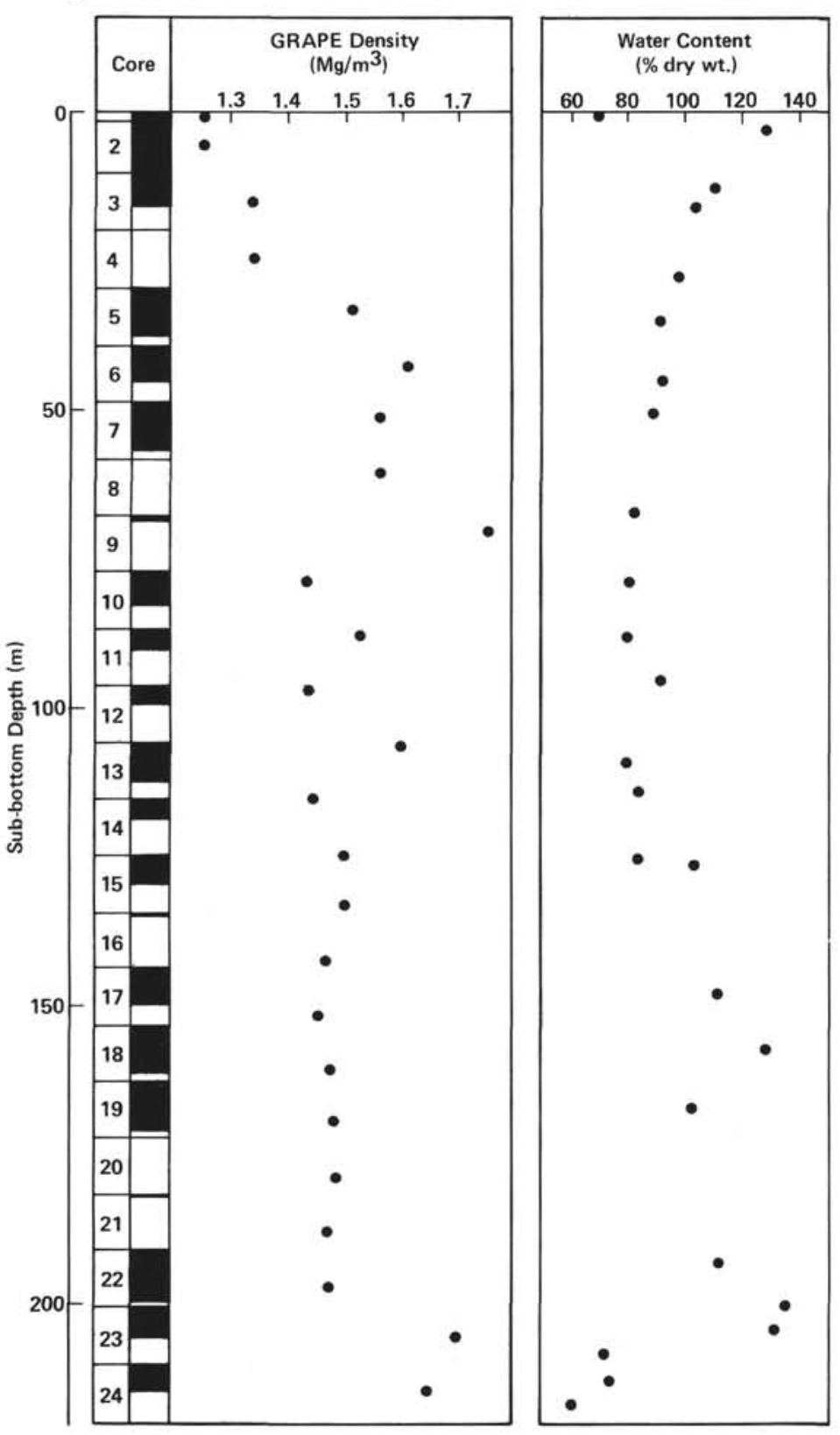

B

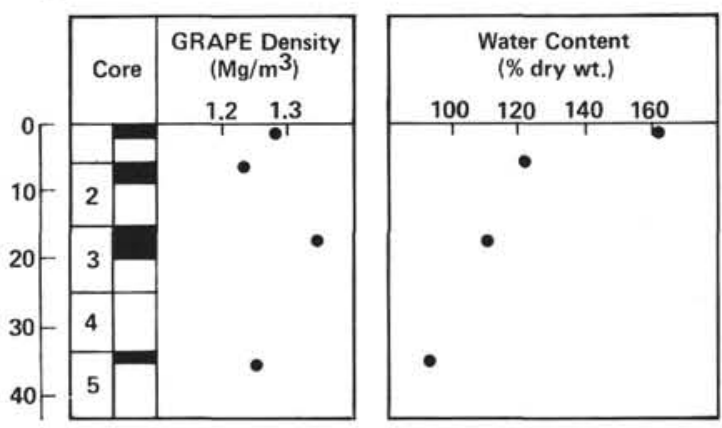

C

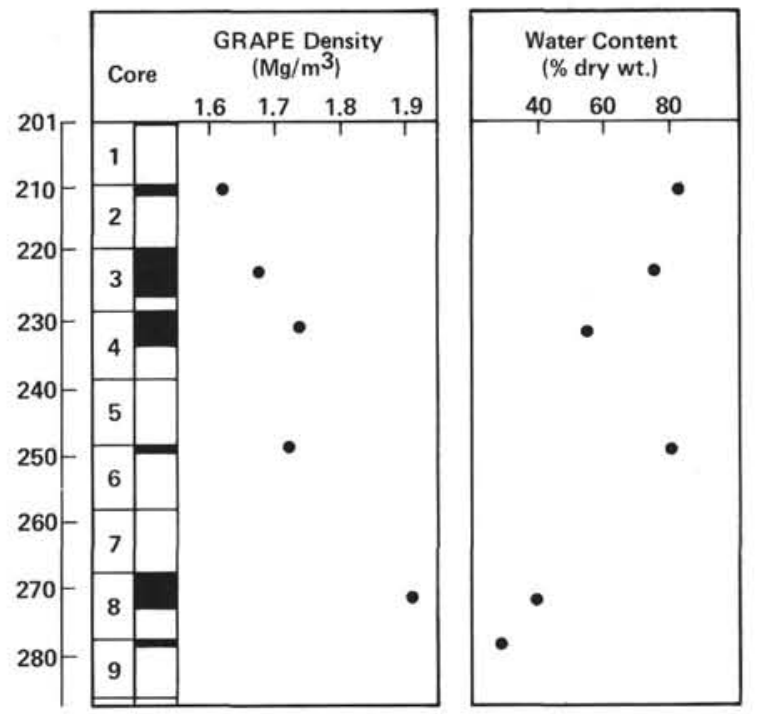

Figure 4. A-C Physical properties for Site 499.

the maximum in Core 8 . The maximum velocity recorded $(5.97 \mathrm{~km} / \mathrm{s})$ was measured on a basalt cobble from the base of the Core 9 core catcher (not plotted).

Determination of the velocity of the Quaternary sediments at Site 499 was unsuccessful.

\section{Shear Strength}

\section{Hole 499}

Shear strength remains low from the mud line down to 110 meters (Core 12), increasing to about $35 \mathrm{kPa}$ (core average) to the base of the section (Fig. 6). Two distinct sedimentary units are thus outlined. (The shear strength measured at Core 12 represents a single measurement in a turbidite unit. If this measurement is dis- regarded, the strength profile would show a gradual increase to a maximum value at 140 meters [Core 15], corresponding to the break between Unit 1 and Unit 2 of Fig. 3.) Table 2 summarizes the physical properties for Holes 499, 499A, and 499B.

\section{GEOPHYSICS}

Site 499 is located on the floor of the Middle America Trench along seismic lines GUA-13 and 18. At Site 499 the trench fill and underlying ocean basin section were penetrated (Fig. 7). The seismic reflections of the trench fill are obscured by diffractions in the low-frequency multichannel records (Fig. 8). Figure 9 is a seismic record obtained by the Challenger; in it two reflective sequences can be seen, a shallower sequence with a gentle 


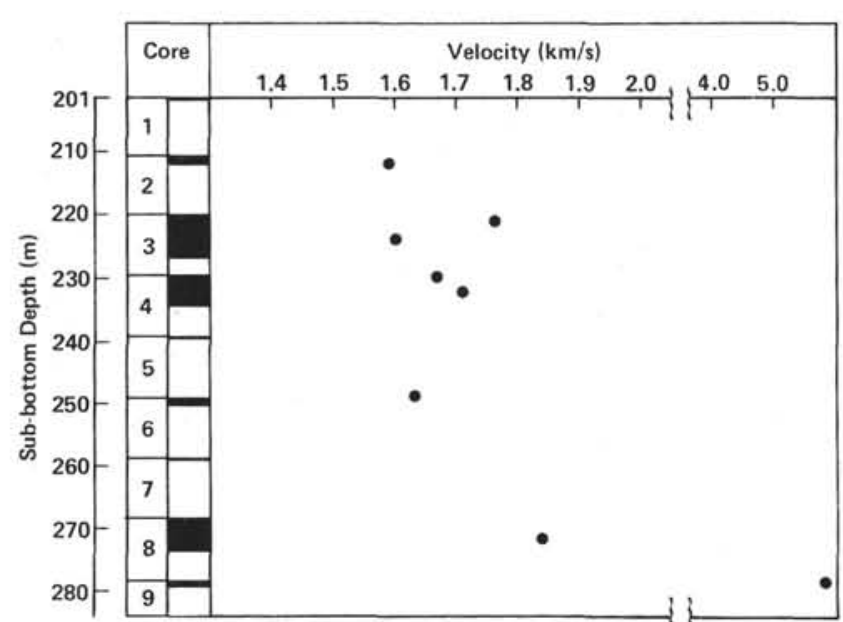

Figure 5. Compressional-wave velocity profile at Hole 499B.

landward dip and a deeper sequence with a steeper landward dip. Because of the 0.17-s bubble pulse, it is difficult to define precisely the interface between the two sequences. But an interface at $0.15 \mathrm{~s}$ sub-bottom would correlate well with the base of the turbidites recovered at 113 meters if a velocity of $1500 \mathrm{~m} / \mathrm{s}$ is used to convert time to depth.

Figures 10 and 11 are $3.5-\mathrm{kHz}$ records recorded by the Challenger that show details of the upper 50 meters of section cored at Site 499. Figure 10 shows the relative positions of the four holes drilled at the site. Three of them were drilled on the seaward side of the trench floor where the surficial layers dip gently landward. Hole 499A was drilled in an apparent channel in the axis of the trench. Figure 10 suggests thinning of the trench fill seaward and gentle deformation with depth. The latter is evidenced by gentle folding of a reflection just below the base of Hole 499A. This reflection rises seaward through a series of monoclinal steps. The turbidite sands recovered at Site 499 came from depths below the reflections seen on the $3.5-\mathrm{kHz}$ records.

On Figure 11 the surficial sediments appear to cover and terminate against some deeper mounds that have no internal reflections. This record was made when the beacon was dropped for Site 499 . The contrast between the well-bedded reflectors in the upper 20 to 50 meters and the deeper reflectorless zone would suggest a lithic contrast. However, no pronounced change in lithology was observed at that level.

On Figure 11 there are local regions where reflections pass laterally into zones in which reflection amplitudes are reduced (e.g., at 0920Z, Point A). In shallow water on the shelf in the Gulf of Mexico such white-out zones are associated with gas pockets. Possibly a similar explanation is valid here.

\section{BIOSTRATIGRAPHY}

Deposits from the Quaternary to the lower Miocene were recovered in Holes 499, 499A, and 499B (Fig. 12). Cores from Holes 499C and 499D contain only weathered basalt.

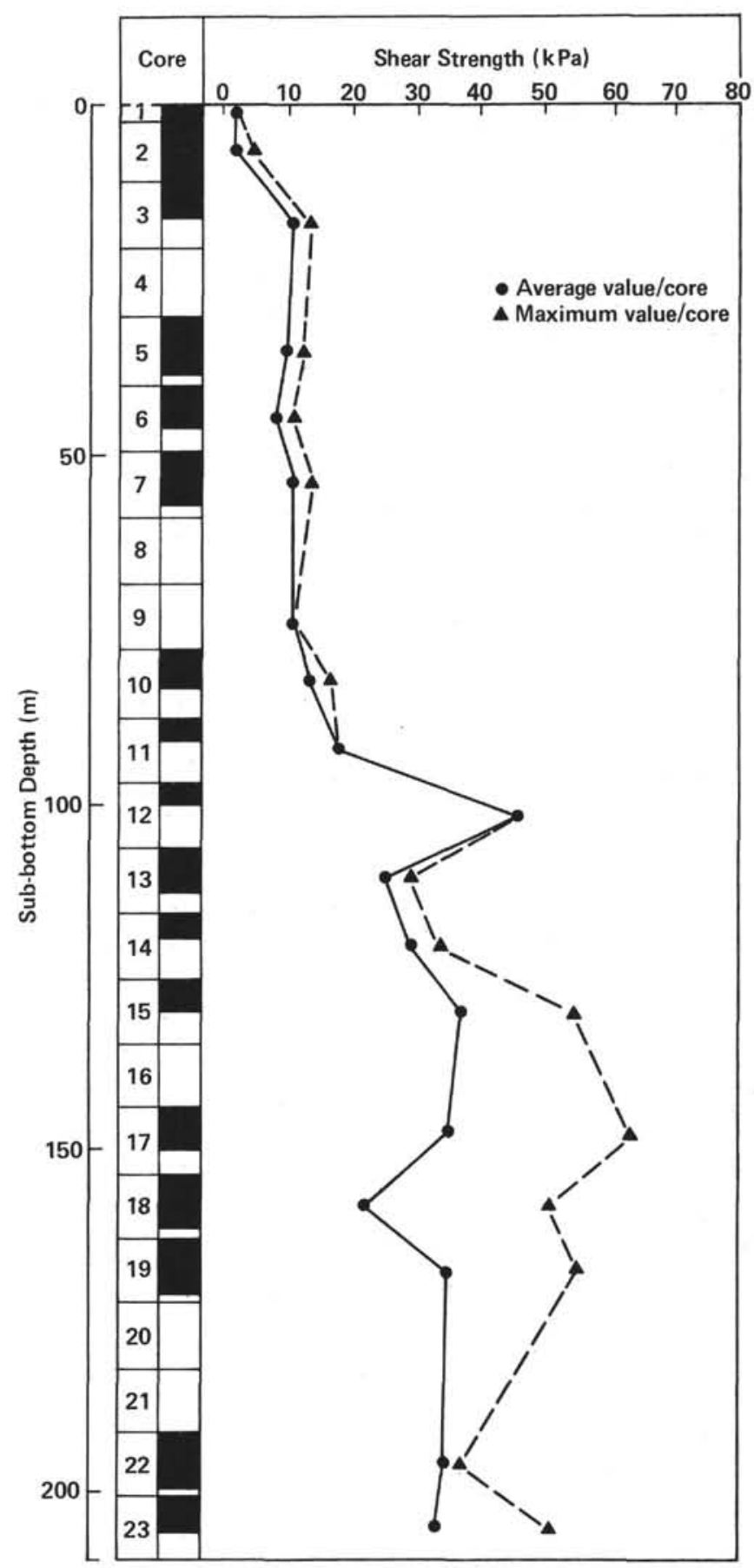

Figure 6. Shear strength profile at Hole 499.

The section begins with Holocene-upper Pleistocene turbidites about 120-meters thick. (Cores 1-13 of Hole 499, Cores 1-5 of Hole 499B). Benthic foraminifers found in these cores consist of three different bathymetric range groups: (1) shelf, (2) upper bathyal, and (3) lower bathyal. Reworked Miocene nannofossils and radiolarians are present in this interval. Microfossils indicate transport to the trench axis.

Below turbidites at Hole 499, nannofossils of the Discoaster brouweri Zone (Core 22) and radiolarians (Cores 21 and 22) date the sediment as late Pliocene. Accumu- 
Table 2. Physical properties, Site 499.

\begin{tabular}{|c|c|c|c|c|c|c|}
\hline $\begin{array}{c}\text { Sample } \\
\text { (core-section, } \\
\text { interval in } \mathrm{cm} \text { ) }\end{array}$ & $\begin{array}{l}\text { GRAPE } \\
\text { Wet-Bulk } \\
\text { Density } \\
\left(\mathrm{Mg} / \mathrm{m}^{3}\right)\end{array}$ & $\begin{array}{l}\text { P. Wave } \\
\text { Velocity } \\
(\mathrm{km} / \mathrm{s})\end{array}$ & $\begin{array}{c}\text { Acoustic } \\
\text { Impedance } \\
\left(\times 10^{3} \mathrm{~g} / \mathrm{cm}^{2} \cdot \mathrm{s}\right)\end{array}$ & $\begin{array}{l}\text { Shear } \\
\text { Strength } \\
\text { (kPa) }\end{array}$ & $\begin{array}{c}\text { Water } \\
\text { Content } \\
(\% \text { dry wt.) }\end{array}$ & $\begin{array}{l}\text { Porosity } \\
\text { (vol. \%) }\end{array}$ \\
\hline \multicolumn{7}{|l|}{ Hole 499} \\
\hline $1-1,138-140$ & - & - & - & 2.29 & 69.90 & 63.92 \\
\hline $2-4,80-82$ & 1.24 & - & - & 2.48 & 128.04 & 76.39 \\
\hline $3-1,133-136$ & 1.35 & - & - & 10.43 & 115.90 & 74.62 \\
\hline $5+1,90-92$ & 1.50 & - & - & 9.76 & 97.94 & 71.23 \\
\hline $5-5,130-132$ & - & - & - & 11.68 & 90.98 & 69.58 \\
\hline $6-4,28-30$ & 1.63 & - & - & 8.61 & 93.08 & 70.12 \\
\hline $7-2,70-72$ & - & - & - & 9.76 & 89.05 & 69.15 \\
\hline $9 \cdot 1,12-14$ & 1,70 & - & - & 10.53 & 82.64 & 67.72 \\
\hline $10-2,128-130$ & 1.52 & - & - & 16.85 & 81.23 & 67.22 \\
\hline $11-3,108-110$ & 1.58 & - & - & 17.23 & 81.42 & 67.22 \\
\hline $12-3,130-132$ & - & - & - & 45.96 & 93.93 & 70.34 \\
\hline $13-4,95-97$ & - & - & - & 21.07 & 80.33 & 66.91 \\
\hline $13-7,38-40$ & - & - & - & 28.73 & - & - \\
\hline $14-3,18-20$ & - & - & - & 34.47 & 83.60 & 67.84 \\
\hline $15-2,140-142$ & - & - & - & 18.38 & 102.60 & 72.33 \\
\hline $15-4,60-62$ & - & - & - & 55.54 & - & - \\
\hline $17-1,100-101$ & 1.51 & - & - & 28.72 & - & - \\
\hline $17-3,63-65$ & 1.44 & - & - & 12.45 & 110.66 & 73.69 \\
\hline $17-5,29-31$ & - & - & - & 64.15 & - & - \\
\hline $18-2,60-62$ & 1.48 & - & - & 4.78 & - & - \\
\hline $18-4,60-62$ & - & - & - & 9.57 & 128.60 & 76.50 \\
\hline $18-6,50-52$ & - & - & - & 50.75 & - & - \\
\hline $19-2,27-29$ & 1.50 & - & - & 10.53 & - & - \\
\hline $19-4,70-72$ & 1.50 & - & - & 44.04 & 102.80 & 72.30 \\
\hline $19-6,50-52$ & - & - & - & 55.54 & - & - \\
\hline $22-1,134-136$ & - & - & - & 35.43 & 112.60 & 74.00 \\
\hline $22-3,134-136$ & - & - & - & 34.47 & - & - \\
\hline $22-5,134-136$ & 1.45 & - & - & 34.47 & 135.10 & 77.30 \\
\hline $23-1,58-60$ & - & - & - & 22.98 & 131.00 & 76.70 \\
\hline $23-1,100-102$ & - & - & - & 23.94 & 72.40 & 64.60 \\
\hline $23-1,140-142$ & - & - & - & 19.15 & 131.00 & 76.70 \\
\hline $23-2,140-142$ & 1.76 & - & - & 51.71 & 65.20 & 62.20 \\
\hline $23-3,138-140$ & 1.65 & - & - & 47.88 & 74.80 & 65.30 \\
\hline $24-1,148-150$ & 1.62 & - & - & - & 59.90 & 60.30 \\
\hline \multicolumn{7}{|l|}{ Hole 499A } \\
\hline $1-1,50-52$ & - & - & - & 6.70 & 160.1 & 80.2 \\
\hline $1-3,110-112$ & - & - & - & 7.85 & - & - \\
\hline $2-1,100-102$ & - & - & - & 6.12 & - & - \\
\hline $2 \cdot 2,58-60$ & - & - & - & 7.66 & 121.7 & 75.4 \\
\hline $3-1,60-62$ & - & - & - & 11.68 & - & - \\
\hline $3-4,70-72$ & - & - & - & 11.87 & 111.1 & 73.7 \\
\hline $5-1,110-112$ & - & - & - & 7.27 & 93.6 & 70.2 \\
\hline \multicolumn{7}{|l|}{ Hole 499B } \\
\hline $2-1,97-100$ & 1.62 & 1.584 & 2.56 & - & 80.7 & 67.1 \\
\hline $3-1,53-55$ & - & 1.765 & - & - & - & - \\
\hline $3 \cdot 3,58-62$ & 1.66 & 1.596 & 2.65 & - & 75.1 & 65.5 \\
\hline $4-1,125-127$ & 1.76 & 1.677 & 2.95 & - & 54.0 & 57.7 \\
\hline $6-1,20-22$ & 1.68 & 1.627 & 2.73 & - & 80.3 & 67.0 \\
\hline $8-3,63-65$ & 1.86 & 1.865 & 3.47 & - & 39.2 & 49.9 \\
\hline $9 \mathrm{CC}, 20-22$ & - & - & - & - & 29.7 & 42.8 \\
\hline
\end{tabular}

lation rates for this and subsequent intervals are indicated in Fig. 13.

A sharp contact between green mud and white chalk occurs in 499-23-1, $83 \mathrm{~cm}$ and in Core 1 of Hole 499B. Upper Miocene radiolarians co-occur with foraminifers representative of lower bathyal depth range.

The chalk part of Cores 499-23 and 499B-1 flank the lower to middle Miocene boundary. Below this level a continuous sequence of the lower Miocene chalk deposits with nannofossils, foraminifers, and radiolarians are recorded in Cores 499-24 and -25 and in Cores 499B-2 through -9. The formation of this deposit took place at a depth below the lysocline, because assemblages of foraminifers and nannofossils contain only dissolution-resistant species.

\section{Foraminifers}

Four lithofacies with distinctive suites of foraminifers were recovered from DSDP Site 499: a Quaternary turbidite trench fill derived from the continental slope, an upper Pliocene to lower Quaternary hemipelagic se- quence, a carbonate-poor siliceous interval ranging from middle Miocene to lower Pliocene, and a carbonate-rich sequence of lower Miocene chalks resting on basalt.

The upper Quaternary turbidites (Hole 499, Cores 1-13; Hole 499A, Cores 1-5) contain foraminiferal assemblages varying in abundance from barren to very numerous and in preservation from highly dissolved to very fresh; often these turbidites include reworked older tests. Size sorting, and possibly shape sorting, are apparent. Typical age-diagnostic plankton taxa include Neogloboquadrina eggeri, Globorotalia fimbriata, and right-coiling Pulleniatina. Benthic taxa Elphidium, Cribroelphidium, Textularia, and Ammonia indicate downslope transport from depths less than 200 meters, Angulogerina, Miliolina, Bolivina, and Spiroloculina from upper bathyal depths less than 1500 meters, and Pullenia, Uvigerina senticosa, and Melonis from lower bathyal depths greater than 1500 meters.

No Pliocene, upper Miocene, or middle Miocene planktonic foraminifers were noted, except in reworked clasts, where they are stained by limonite(?). Lower bathyal or abyssal benthic foraminifers including Martinottiella and Cyclammina were found in the carbonate-poor interval in Samples 499-23-1, $75 \mathrm{~cm}$ and 499B-1-1, 9-11 cm. Those mottled siliceous units are possibly correlative to the brown clay at Site 495 , Cores 16 through 19.

The lower Miocene chalks in Samples 499-23-1, $90 \mathrm{~cm}$ through 499-25, CC and in Hole 499B, Cores 2 through 9, CC are divided into two subgroups on the basis of carbonate preservation: The amber-colored chalks contain a large number of foraminiferal test fragments, few small individuals, and great quantities of dissolutionresistant materials such as radiolarians, echinoid spines, and fish teeth; the gray green to gray blue chalks, in contrast, have much higher species diversity, small-sized taxa, and fewer dissolution-resistant objects. Foraminiferal Zones N7 through N4 are present. The N7/N6 boundary is placed between Cores 3 and 4 in Hole 499B on the basis of the extinction of Catapsydrax dissimilis. The N6/N5 boundary based on the first appearance of Globigerinatella insueta and the N5/N4 boundary based on the extinction of Globorotalia kugleri could not be accurately located because of dissolution. Cores 8 and 9 in Hole 499B are in the upper part of Zone N4.

\section{Radiolarians}

Radiolarians from the lower Miocene to the Quaternary were recovered in cores from Site 499 . Generally assemblages are diverse and moderately well preserved, but in the upper part, Cores 499-1 through -13 and 499A-1 through -5 , they are diluted with terrigenous mud.

The usual Quaternary assemblage, found in all the sites of Leg 67, dominates the first 19 cores of Hole 499 and Cores 1 through 5 of Hole 499A. Substantial numbers of Miocene species were reworked in the samples examined from Hole 499-Cores 2, 3, 5, 6, 10, 12, 14, and 17. Axoprunum angelinum, first noted in Sample 


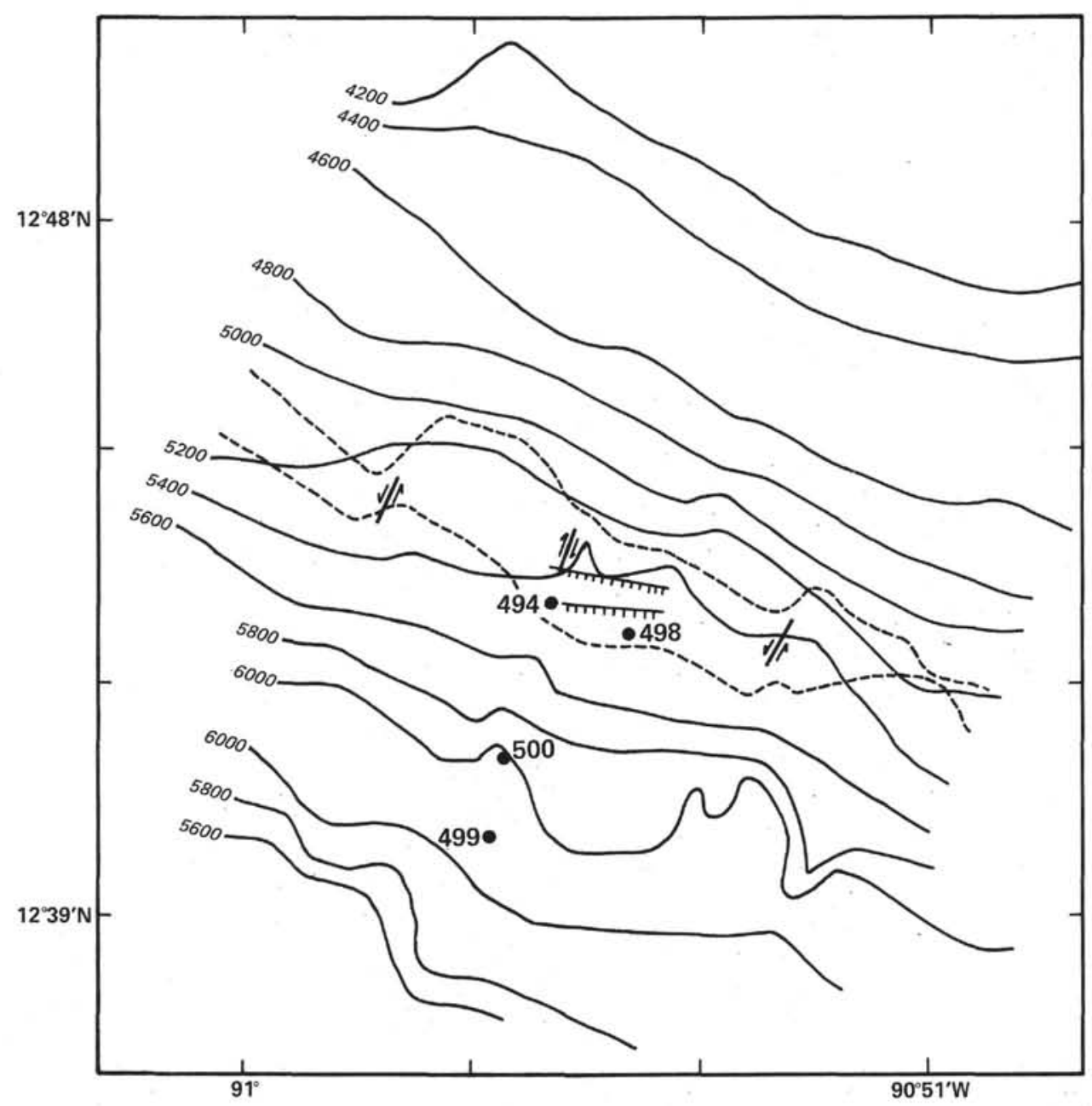

Figure 7. Bathymetry of the Middle America Trench axis off Guatemala.

499-15-3, 102-103 cm, indicates an age greater than 0.4 m.y. Anthocyrtidium angulare was found in very small numbers in samples from Cores 499-18 and -19, indicating the lowermost Quaternary.

The Pliocene/Pleistocene boundary cannot be determined with confidence on the basis of radiolarian evidence because of the absence of the marker species Pterocanium prismatium and the low numbers of Lamprocyrtis heteroporos, L. neoheteroporos, Theocorythium vetulum, and T. trachelium. However, Anthocyrtidium angulare occurs in Cores 18 and 19, and the lower boundary of that zone is therefore tentatively drawn between Samples 499-19-3, 110-112 cm and 499-19-6, $10-12 \mathrm{~cm}$.

Core 499-23 shows a sharp contact between siliceous biogenic mud and nannofossil ooze at $83 \mathrm{~cm}$. Three samples above the contact, at 20 to $22 \mathrm{~cm}, 40$ to $42 \mathrm{~cm}$, and 69 to $71 \mathrm{~cm}$, are all from the upper Miocene Didymocyrtis antepenultima Zone. These samples span a period from about 10 to $8 \mathrm{Ma}$. The evolution of $D$. laticonus to $D$. antepenultima to $D$. penultima is easily seen in the relative abundances of those species. The extinction of Diartus pettersoni and increasing numbers of Stichocorys peregrina are also evident in this interval.
Below the contact, at Sample 499-23-1, 102-104 cm and Sample $499-23, C C(10-12 \mathrm{~cm})$, radiolarians are from the middle Miocene Dorcadospyris alata Zone of about 15 m.y. in age.

Sample 499-24-1, 16-18 cm contains a typical assemblage from the lower Miocene Calocycletta costata Zone. Smaller numbers of $C$. costata and $L$. stauropora in the next sample, 499-24-3, 84-86 cm, indicate the lowest part of that zone at about $17 \mathrm{Ma}$.

The deepest sample examined from Hole 499, Sample $499-25-4,102-104 \mathrm{~cm}$, is considered to be from the $S$. wolffii Zone ( $\sim 19 \mathrm{~m} . \mathrm{y}$. old) because of the absence of C. costata and presence of Lychnocanoma elongata.

Hole 499B was washed to 201 meters, the level of Core 499-23. The core catcher of the first core showed three lithologies. A light colored, coarse layer contains a mixed assemblage of about $25 \%$ upper Miocene $D$. antepenultima Zone, and about $75 \%$ middle Miocene $D$. alata Zone. A sample from the dark green gray mud at 9 to 11 meters contained a good assemblage from $D$. antepenultima Zone, with a very small number of middle or lower Miocene species. The light nannofossil ooze at the bottom contains an assemblage from the $D$. alata Zone. Sections 499B-2-1 and 499B-3-1 are assigned to the $C$. 


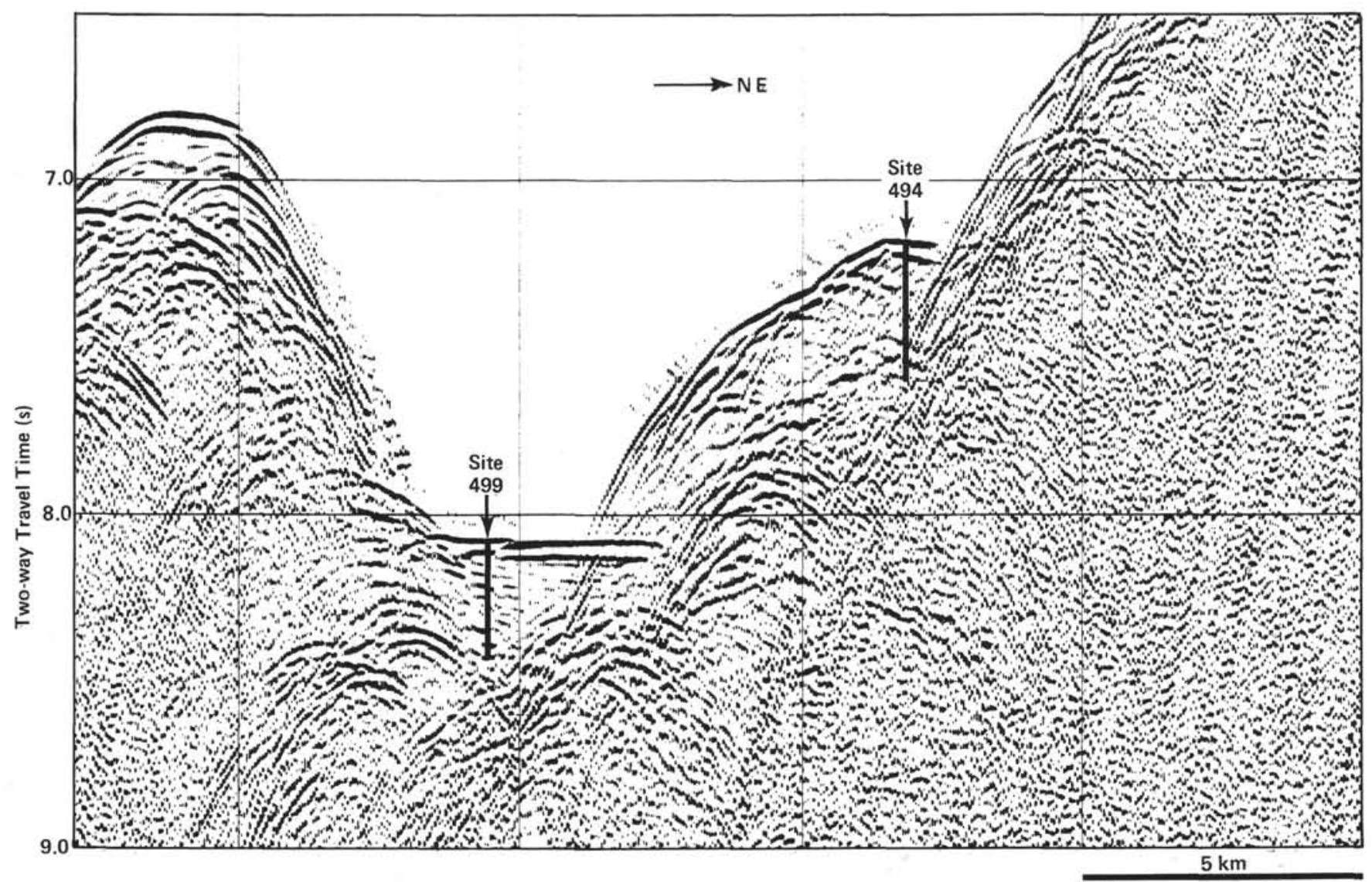

Figure 8. Low-frequency seismic-reflection profile GUA-13 recorded across the Middle America Trench axis.

costata Zone (16-17 m.y. old) because of the presence of Dorcadospyris dentata, Eucyrtidium diaphanes, and greater numbers of Liriospyris stauropora than its descendent, L. parkerae.

In Section 499B-3-4, the absence of $C$. costata, D. dentata, and $L$. stauropora, the presence of $L$. elongata, and the abundance of $S$. wolffii indicate the lower Miocene $S$. wolffii Zone ( $\sim 19$ m.y. old).

Hole 499B, Core 4, is evidently below the first appearance of $S$. wolffii, and contains greater numbers of $D$. tubarius than $D$. violina, indicating $S$. delmontensis Zone (about 19.5-21.5 m.y. old). Core 6 also contains an assemblage from this lower Miocene zone. No samples from Cores 5 or 7 were examined, and Cores 8 and 9 were barren of radiolarians. This termination of radiolarian assemblages in the $S$. delmontensis Zone, followed by a barren interval and then basalt, corresponds to the oceanic reference Site 495 .

\section{Nannoplankton}

Turbidites of Cores 499-1 to 499-13 contain nannoplankton assemblages of Emiliania huxleyi/Gephyrocapsa oceanica Zones. Nannoplankton are rare to common, and their preservation is good. Core 9 includes a sandy layer, consisting of fragments of white chalk with a rich assemblage of the middle Miocene Sphenolithus heteromorphus Zone. Nannoplankton are rare in the muddy members of the section from Core 499-10 to Sample 499-22-2, 60-62 cm, and they are of the lower Pleistocene Crenalithus doronicoides Zone.

Core 499-22 mud corresponds with the upper Pliocene Discoaster brouweri Zone. Nannoplankton are rare to few.

The contact between siliceous biogenic muds and chalks is in Core 23. Nannoplankton were not found in muds of this core. Chalk of Cores 499-23 to 499-24 and of Cores 499B-1 to 499B-2 contain the lower Miocene Sphenolithus heteromorphus Zone assemblage with index species $D$. exilis, $D$. deflandrei, $D$. signus, and some others.

Cores 499-24 and 499-25 and Core 499B-3 correspond to the lower Miocene Helicopontosphaera ampliaperta Zone. Nannoplankton assemblages of $D$. druggii and $D$. deflandrei Subzones and Triquetrorhabdulus carinatus Zone were found in Core 499B-4 to Sample 499B-9,CC. The assemblage of this zone is distinguished from the subzones just mentioned by the presence of $T$. carinatus. The presence of $D$. druggii is characteristic of the upper subzone of the zone.

\section{GEOCHEMISTRY}

\section{Organic Geochemistry}

The hydrocarbon-monitoring program used at pre- 


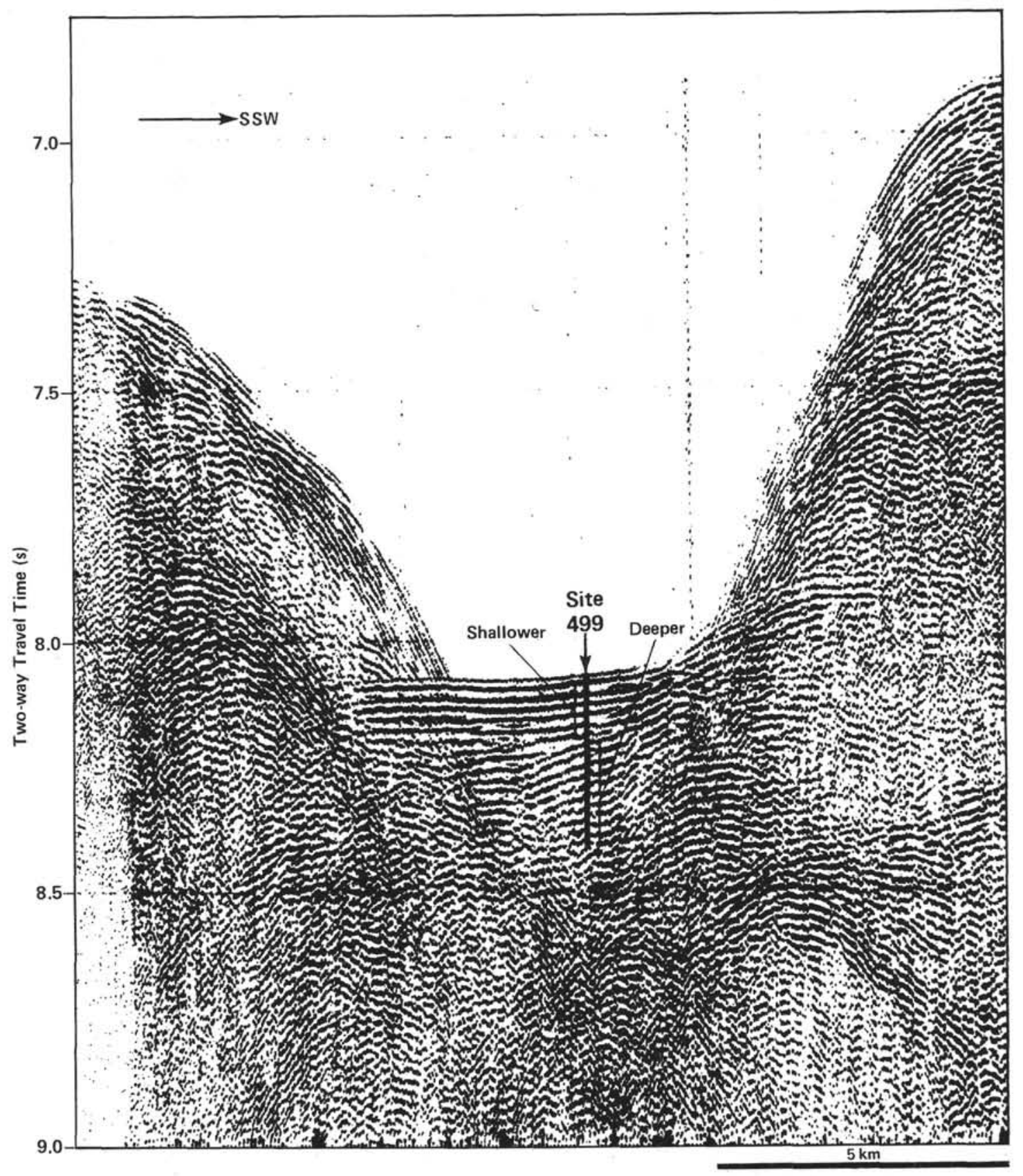

Figure 9. Seismic-reflection profile showing two reflective sequences (a shallower one and a deeper one) within the Middle America Trench axis.

vious Leg 67 sites was continued at Site 499 . The methane/ethane ratios for Site 499 samples are shown in Figure 14. Ratio values for the upper one-half of the cores are greater than 100,000 . In the lower portion of the penetrated section, there were three values less than $100,000(38,900$ at $100 \mathrm{~m}, 93,00$ at $117 \mathrm{~m}$, and 99,000 at $118 \mathrm{~m}$ ). Below 150 meters, methane was less than $10 \%$ of the total gas sampled, and there were no indications of higher molecular-weight components. Thus detailed analyses on the Hewlett-Packard gas chromatograph were not made regularly. Figure 15 shows details of the methane and ethane distribution in Site 499 samples. Methane averaged about $65 \%$ to $75 \%$ (of total gas sam- pled and analyzed), except where poor core recovery resulted in unreliable sampling. Ethane was present only in trace quantities (maximum of $21 \mathrm{ppm}$ ) throughout the penetrated section.

The uppermost sediments at Site 499 are turbidites. The gaseous components present represent the original quantities minus that portion lost while the turbidite was emplaced. If the turbidite moved down the continental slope to the present trench site as a highly agitated and fluidized mass of water and sediment, it might be expected that a considerable portion of the initial gas content would have been lost in transit. By comparison, if sediment from the continental slope was transported 


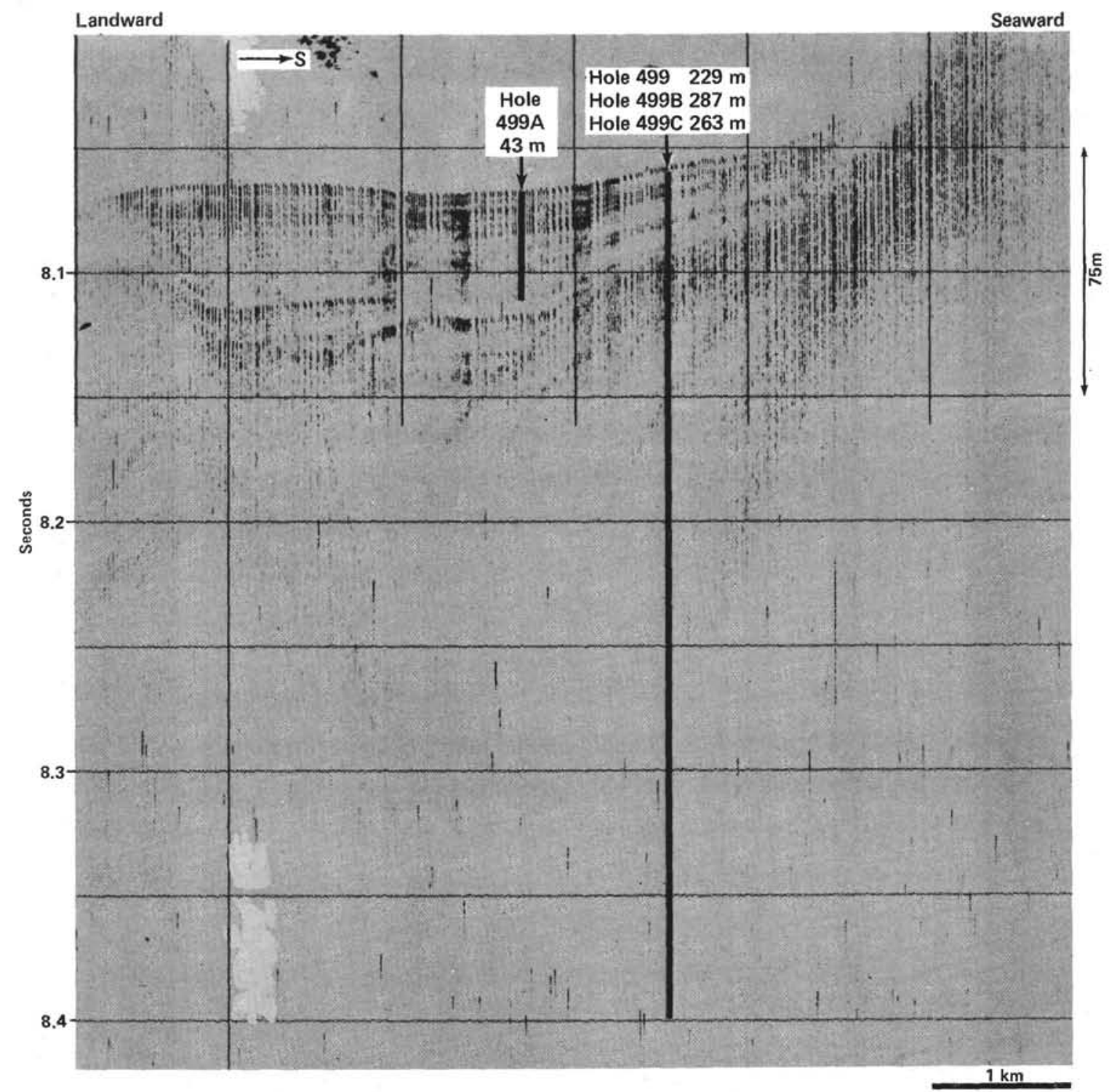

Figure 10. Details of the uppermost 50 meters of section cored at Site 499 are shown in this $3.5-\mathrm{kHz}$ seismic-reflection profile.

as a relatively intact body, then a major portion of the original gas content might well have been preserved (except near the surface that underwent movement). The ethane content of previous Leg 67 slope sites was as much as several hundred ppm; thus the sediment transported downslope to Site 499 either must have had considerably lower initial ethane concentrations than Sites 496 or 497 or it must have lost most of the ethane and heavier components during transport. Methane content at Site 499 was about the same as that encountered at Sites 496 and 497 . If the gas concentrations are similar everywhere on the Guatemalan slope, perhaps mechanism loss during transport is responsible for the low gas content of Site 499 . The processes that resulted in significantly lower ethane concentrations at Site 499 would have affected methane in the same manner. Under these conditions, the methane found at Site 499 must be attributed to microbial processes and must have been generated after emplacement of the turbidite deposits.

\section{Inorganic Geochemistry}

Data from the shipboard interstitial water program are presented in Figure 16. Chlorinity and $p \mathrm{H}$ are fairly constant throughout the penetrated interval. Salinity, alkalinity, and magnesium have similar patterns; all three parameters have two maxima (at 9 and $120 \mathrm{~m}$ ) and two minima at (46 and $223 \mathrm{~m}$ ). These patterns are unusual and are undoubtedly affected by turbidite sedimentation. Calcium concentrations appear to be inversely related to those of magnesium. The calcium maximum occurs at about 55 meters, and this same point marks the minimum value for magnesium.

\section{SUMMARY AND CONCLUSIONS}

The five holes drilled at Site 499 on the Middle America Trench floor are at water depths between 6126.5 and 6132 meters. Seismic-reflection records across the trench in this location register a sequence of horizontal reflec- 


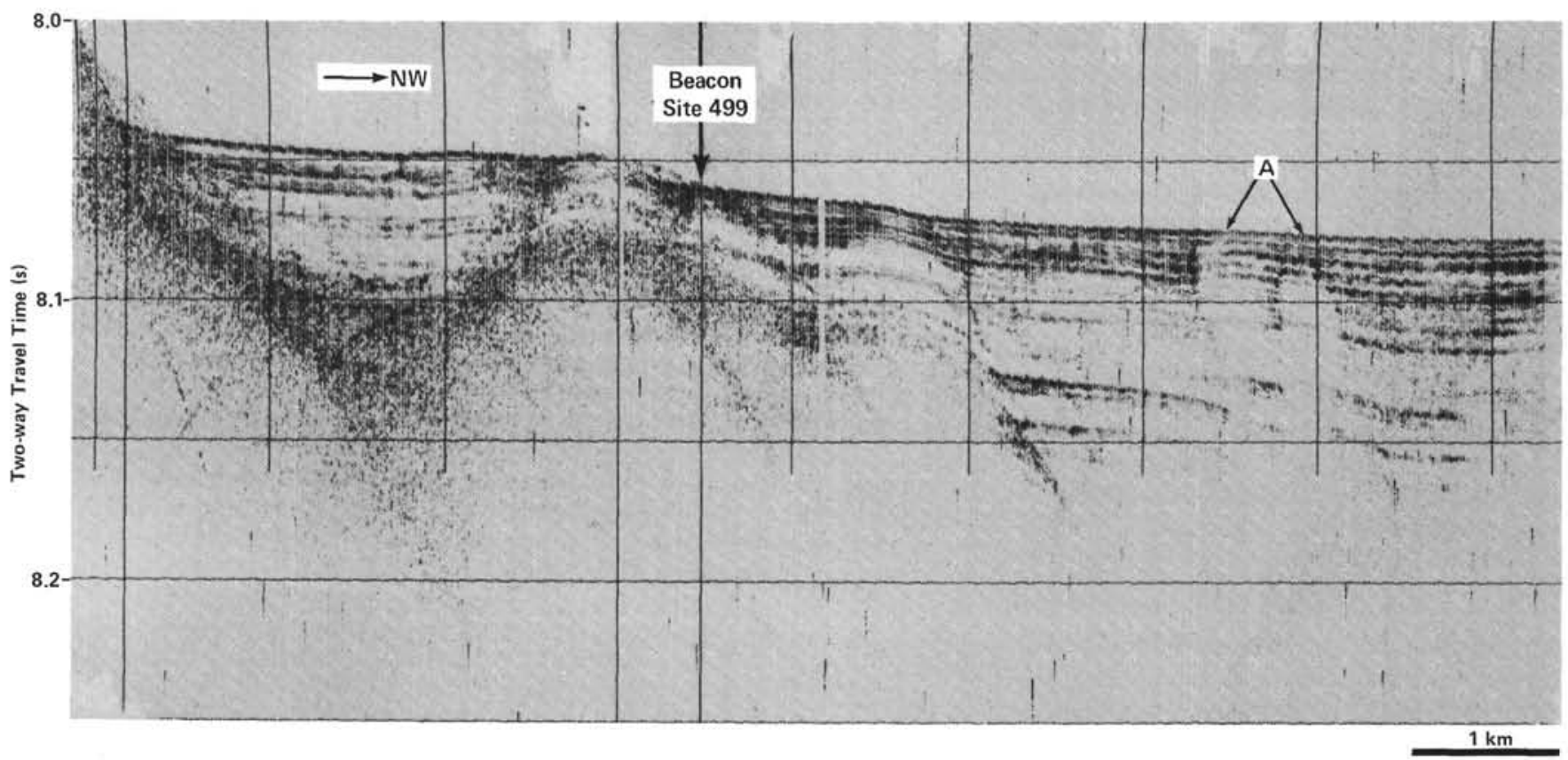

Figure 11. A 3.5-kHz seismic-reflection profile showing details of the uppermost 50 meters of section cored at Site 499 .

\begin{tabular}{|c|c|c|c|}
\hline Series & $\begin{array}{l}\text { Sample } \\
\text { (hole-core-section, } \\
\text { interval in } \mathrm{cm} \text { ) }\end{array}$ & $\begin{array}{l}\text { Approximate } \\
\text { Sub-bottom } \\
\text { Depth of } \\
\text { Boundary }(\mathrm{m})\end{array}$ & Basis for Boundary Position \\
\hline Quaternary & $\begin{array}{l}499-1 \rightarrow 21 \text {, and } \\
499 A-1 \rightarrow 5\end{array}$ & 191 & Top of $D$. brouweri Zone \\
\hline upper Pliocene & $499-22$ & 200.5 & Base of $P$. prismatium Zone \\
\hline upper Miocene & $499-23-1,0-83 \mathrm{~cm}$ & 201.3 & Base of $D$. antepenultima Zone \\
\hline $\begin{array}{l}\text { lower } / \text { middle } \\
\text { Miocene }\end{array}$ & $\begin{array}{l}499-23-1,83 \mathrm{~cm} \rightarrow 23, \mathrm{C} \\
499 \mathrm{~B}-1, \mathrm{CC}\end{array}$ & 210 & $\begin{array}{l}\text { Base of S. heteromorphus Zone } \\
\text { D. alata Zone, and N7 }\end{array}$ \\
\hline lower Miocene & $\begin{array}{l}499-24-1 \rightarrow 25 \text { and } \\
499 \mathrm{~B}-2 \rightarrow 9, \mathrm{CC}\end{array}$ & 277.4 & Base of $D$. deflandrei Subzone \\
\hline Basalt & 499B-10 & 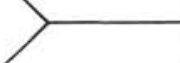 & \\
\hline
\end{tabular}

Figure 12. Stratigraphic series at Holes 499, 499A, 499B.

tions underlain by a sequence of gently landward-dipping reflections. The location of Hole 499 was selected to avoid sampling the thickest parts of both acoustic sequences and to avoid sampling sand that might fill an axial channel. After drilling a muddy upper section, the axial channel was drilled at $499 \mathrm{~A}$, without recovering sand. Hole 499 was paralleled and drilled to basement at
Hole 499B. The rubbly nature of the basalt recovered impeded drilling, and Hole 499C, offset $1000 \mathrm{ft}$. along strike, was washed to rubbly, basaltic basement. Hole 499D was drilled for logging.

The lithologies at Site 499 are a repeat of those at Site 495 , the oceanic reference site, but with the addition of a cover of trench-fill turbidite. These turbidites, 117 me- 


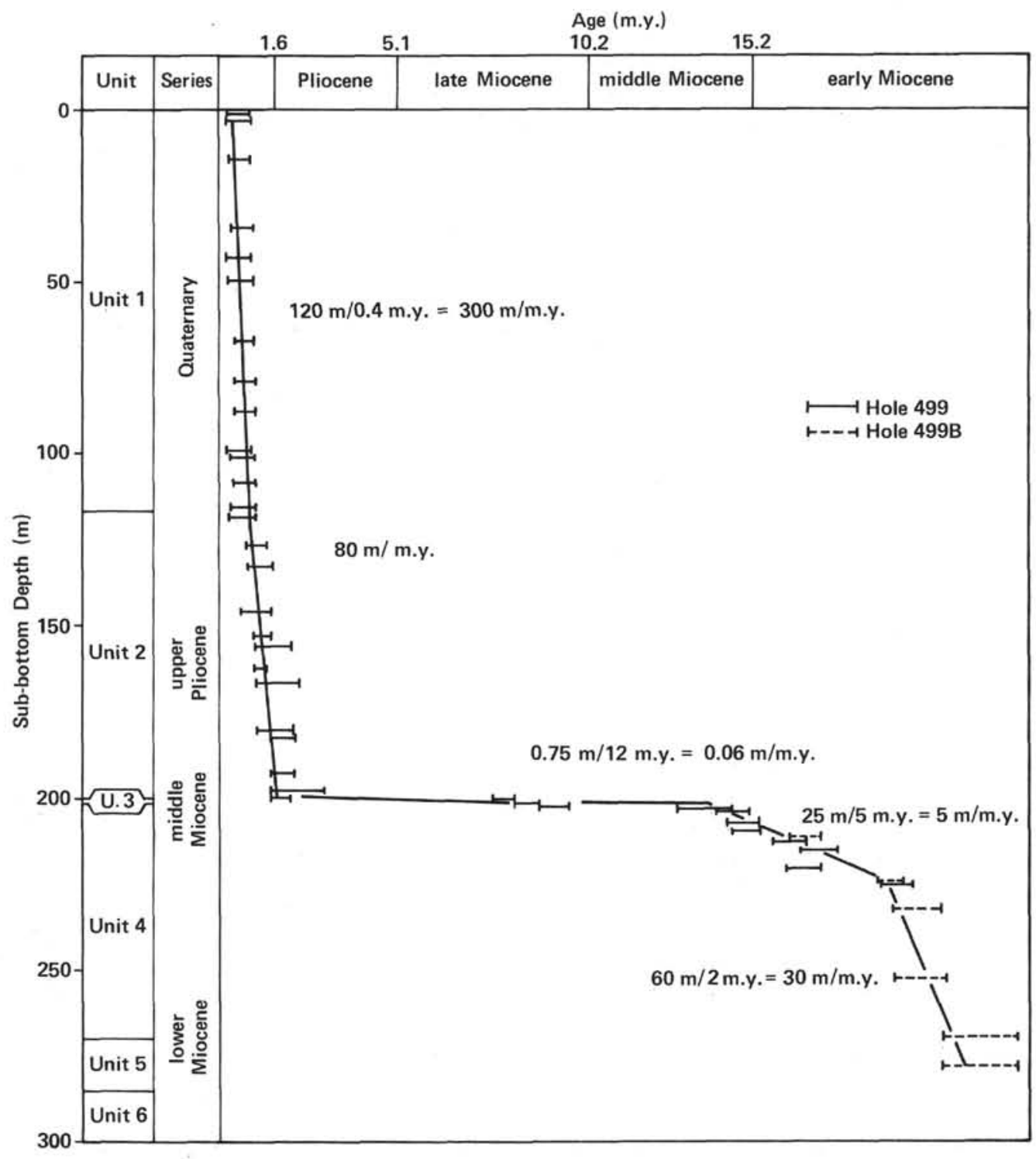

Figure 13. Sedimentation rate curve for Site 499.

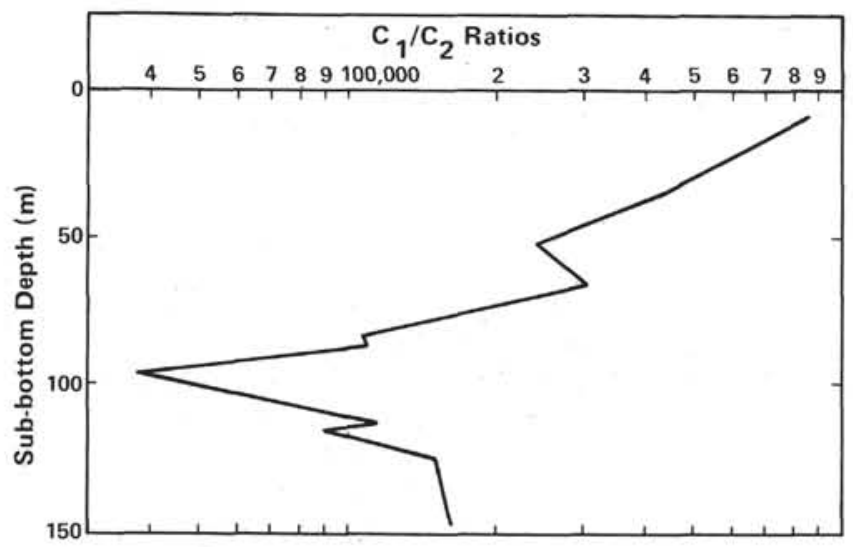

Figure 14. Methane/ethane ratios for Site 499.

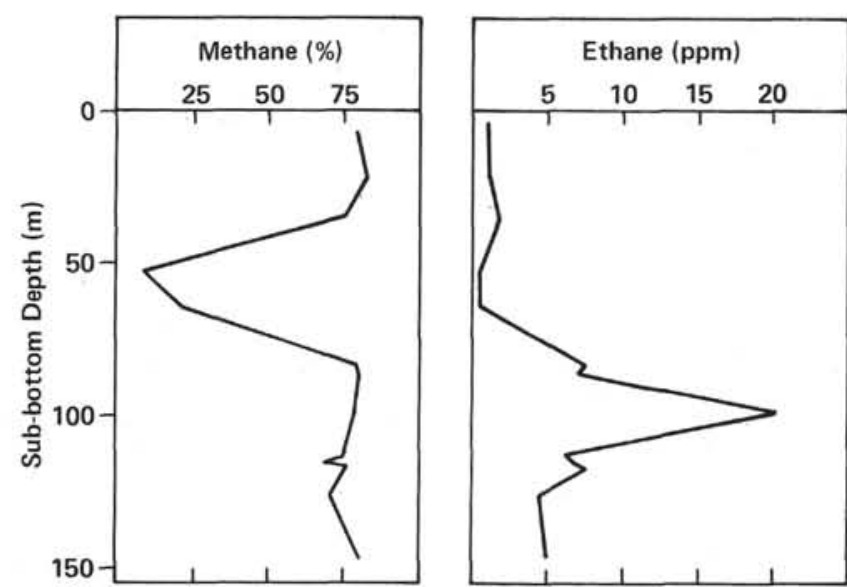

Figure 15. Methane and ethane concentrations at Site 499. 


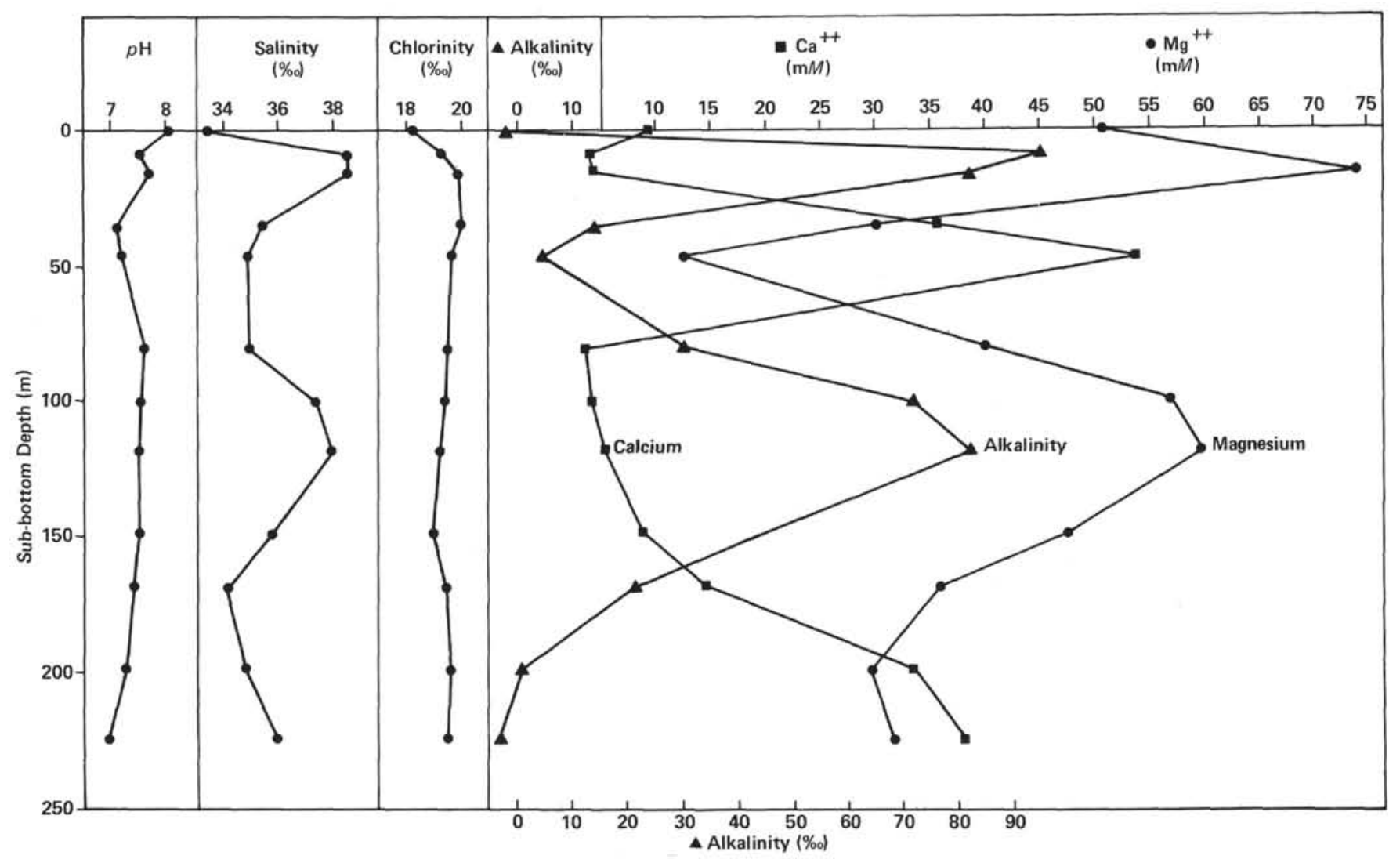

Figure 16. Interstitial water studies at Site 499.

ters thick, are predominantly muddy, although preferential recovery of mud versus sand is suspected. The same turbidite units appear in the channel, about $1 \mathrm{~km}$ away, at Hole 499A without any apparent lateral change. In Hole 499, turbidites end abruptly, and burrow mottled, hemipelagic muds, calcareous ooze and chalk, and basalt rubble follow in that order. Although the sequence resembles that cored at Site 495, the calcareous section at Site 499 is about one-third as thick.

Microfossils occur in the same succession as at Site 495 , with the addition of the sequence in the Quaternary trench fill. The trench fill has abundant reworked and transported calcareous microfossils, and the 400,000-yr. radiolarian zonal marker becomes abundant below the trench fill. Within the calcareous section there is more dissolution of foraminifers than at 495 , indicating deposition nearer the CCD. The oldest sediment was deposited in the earliest Miocene, as at Site 495.

The trench is filled with a uniform upper Quaternary sequence (slightly less than 400,000 yr. old) of alternating muddy and sandy turbidites, transported from shal- lower areas landward and deposited rapidly. The youth of these deposits implies rapid subduction, but the age is not known with enough precision to test more than gross rates of plate convergence. The basalt rubble encountered at various depths above seismic basement may be depositional rather than oceanic crust. Beneath the turbidite fill, there is an abbreviated but complete oceanic section, therefore the sequence of sediment corresponds to the two units suggested by the seismic reflectors. The cause of the abbreviated oceanic section is undetermined, but it may result from irregularities in basement relief perhaps inherited from conditions at the spreading center. Alternatively, the section at Site 495 may be anomalously thick.

\section{REFERENCES}

Hess, R., 1977. Softer radiographs of sliced piston cores from the Japan and southern Kuril Trench and slope areas. In Honza, E. (Ed.), Geological Investigation of Japan and Southern Kurile Trench and Slope Areas, GH76-2 Cruise, April-June 1976. Geol. Surv. Jpn. Cruise Rep. 7, pp. 86-108. 


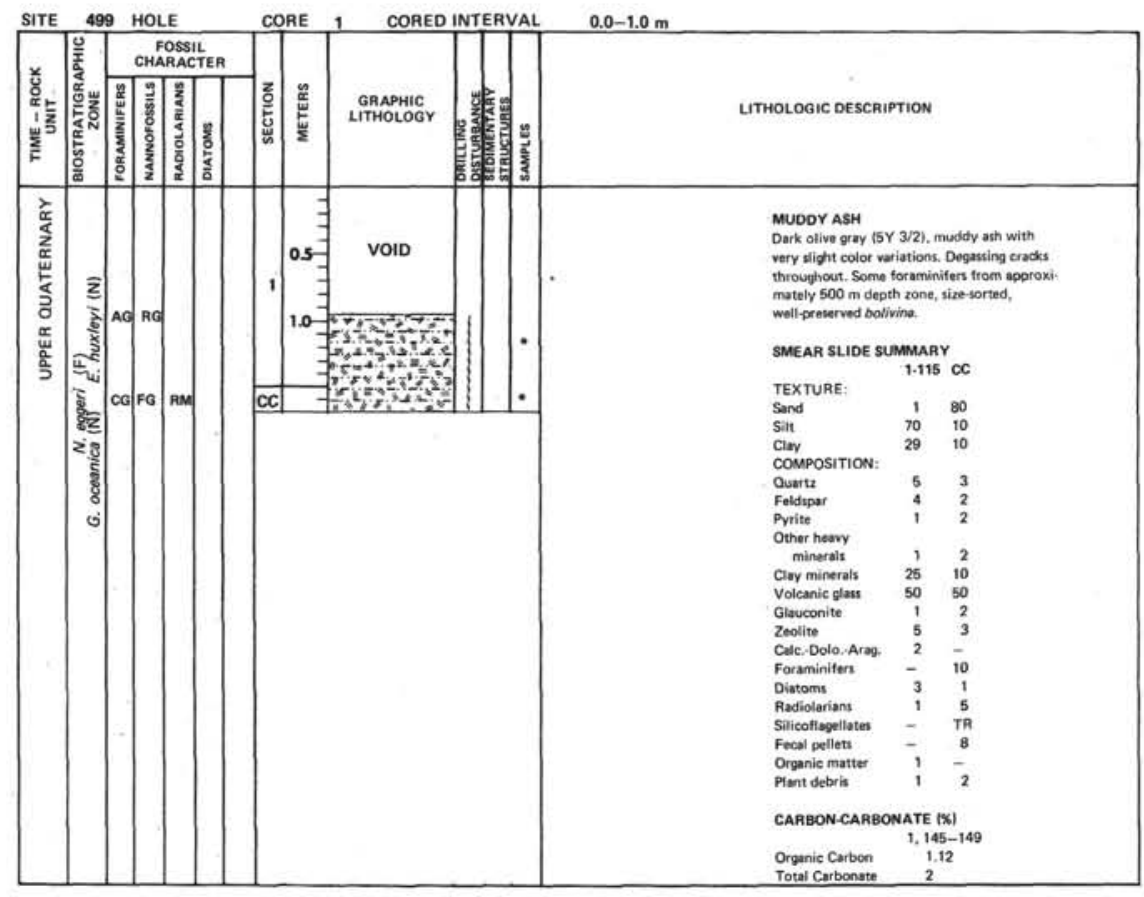

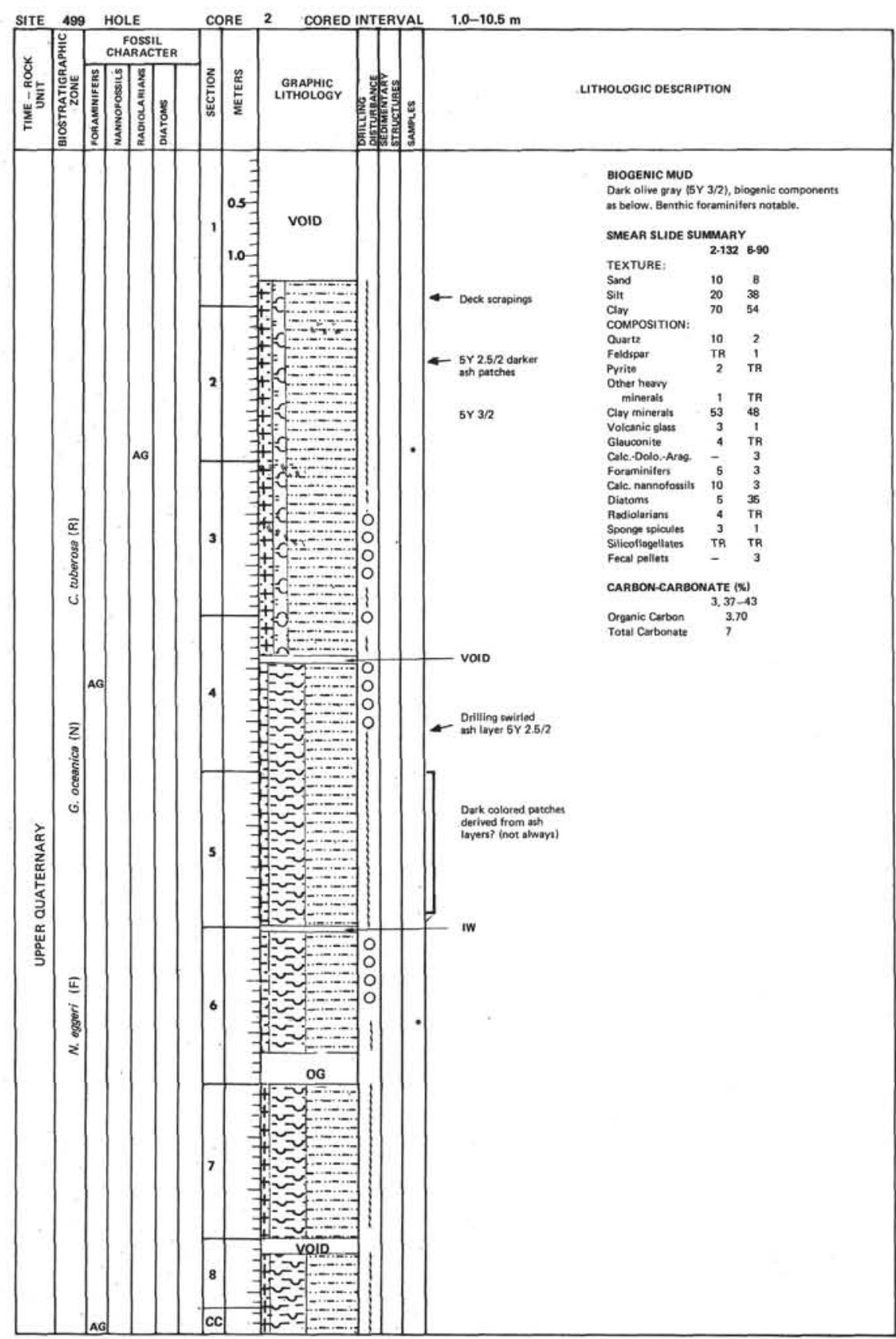




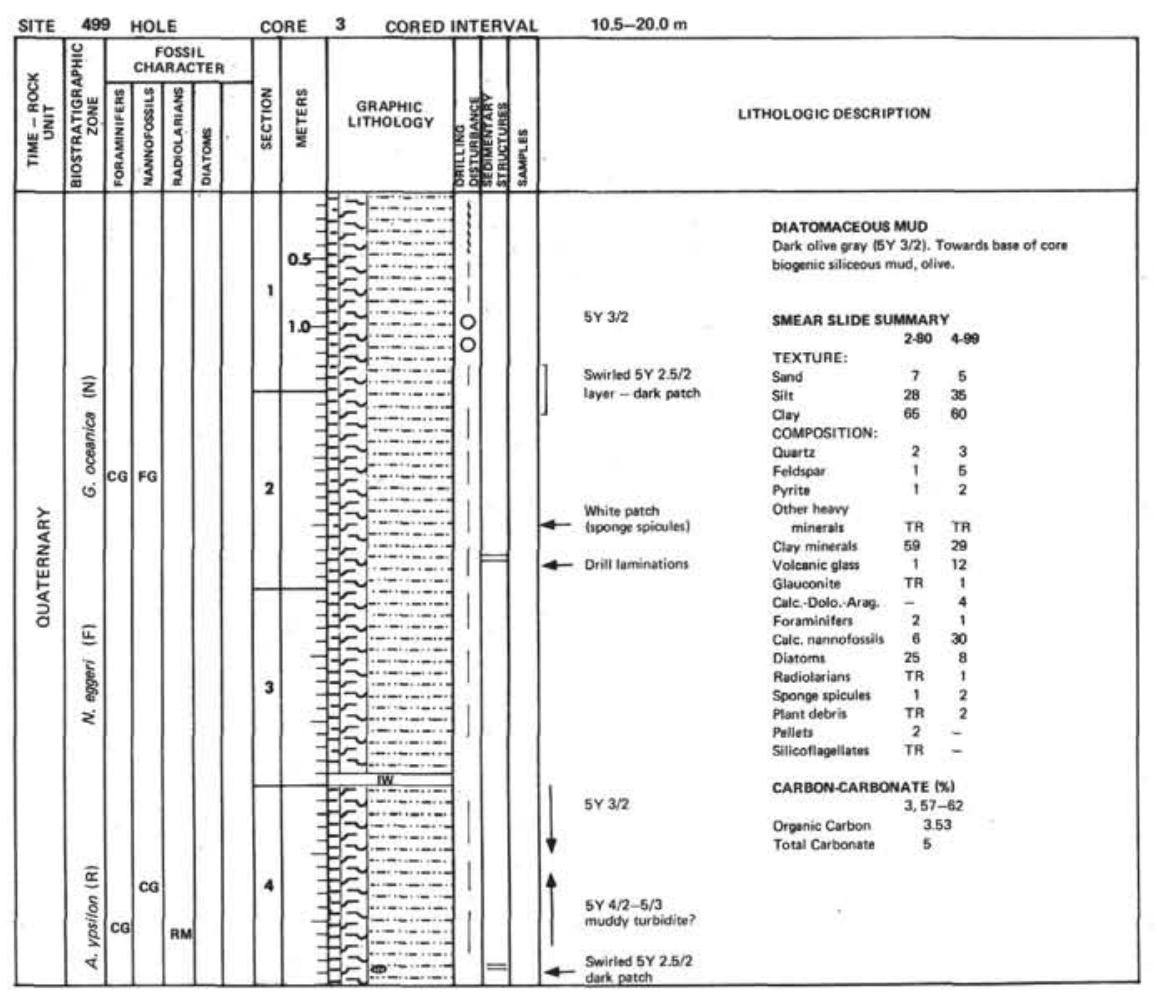

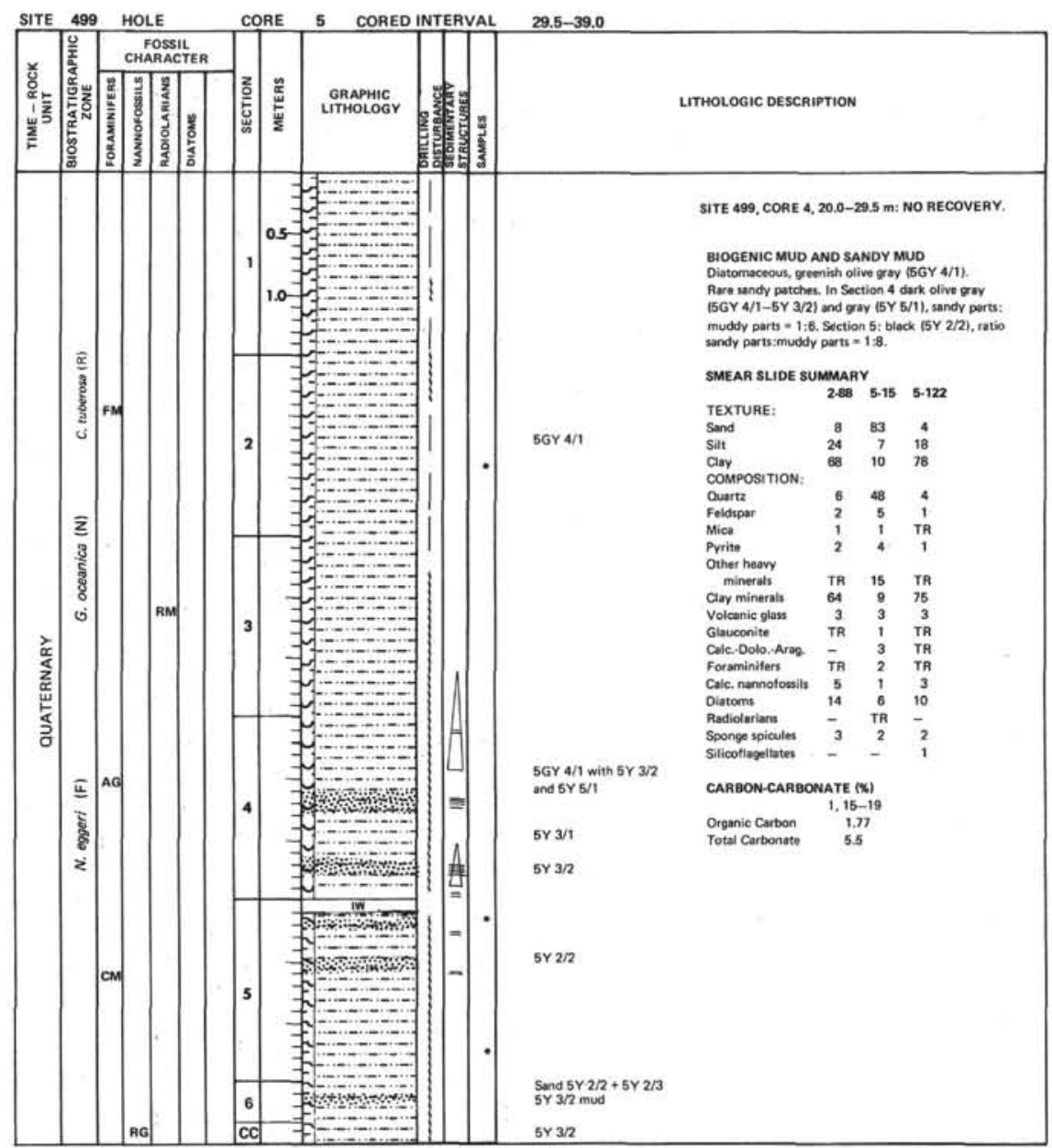




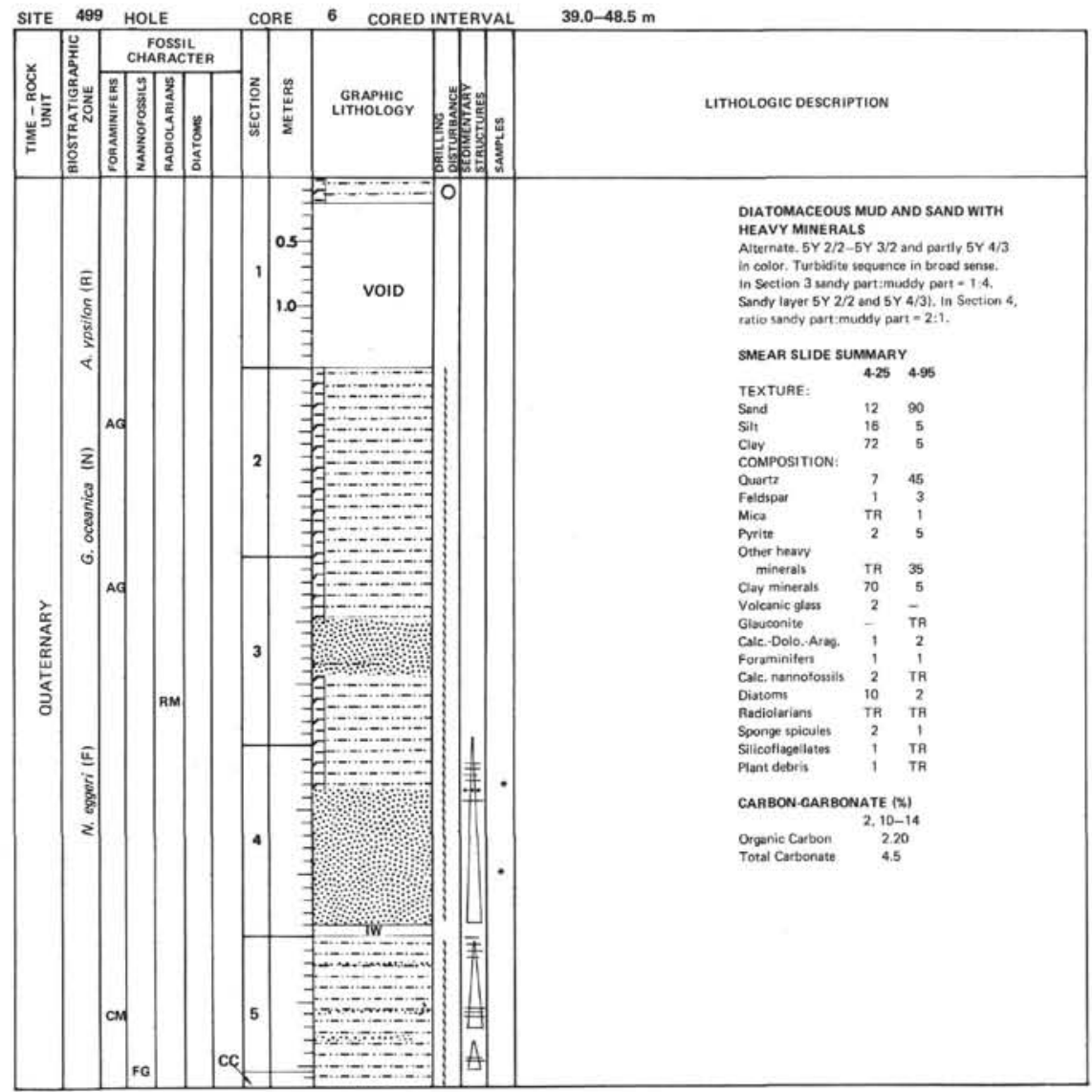

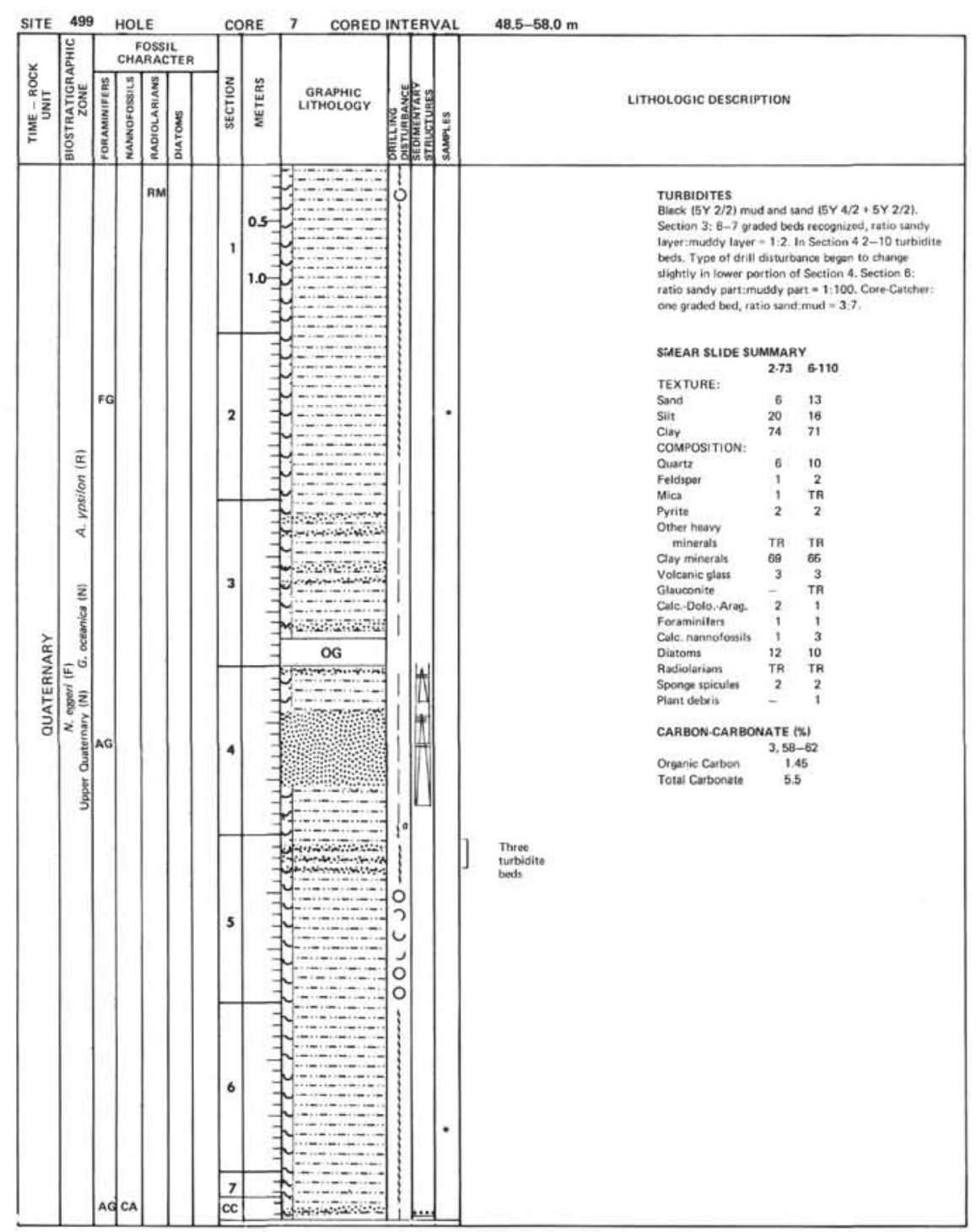



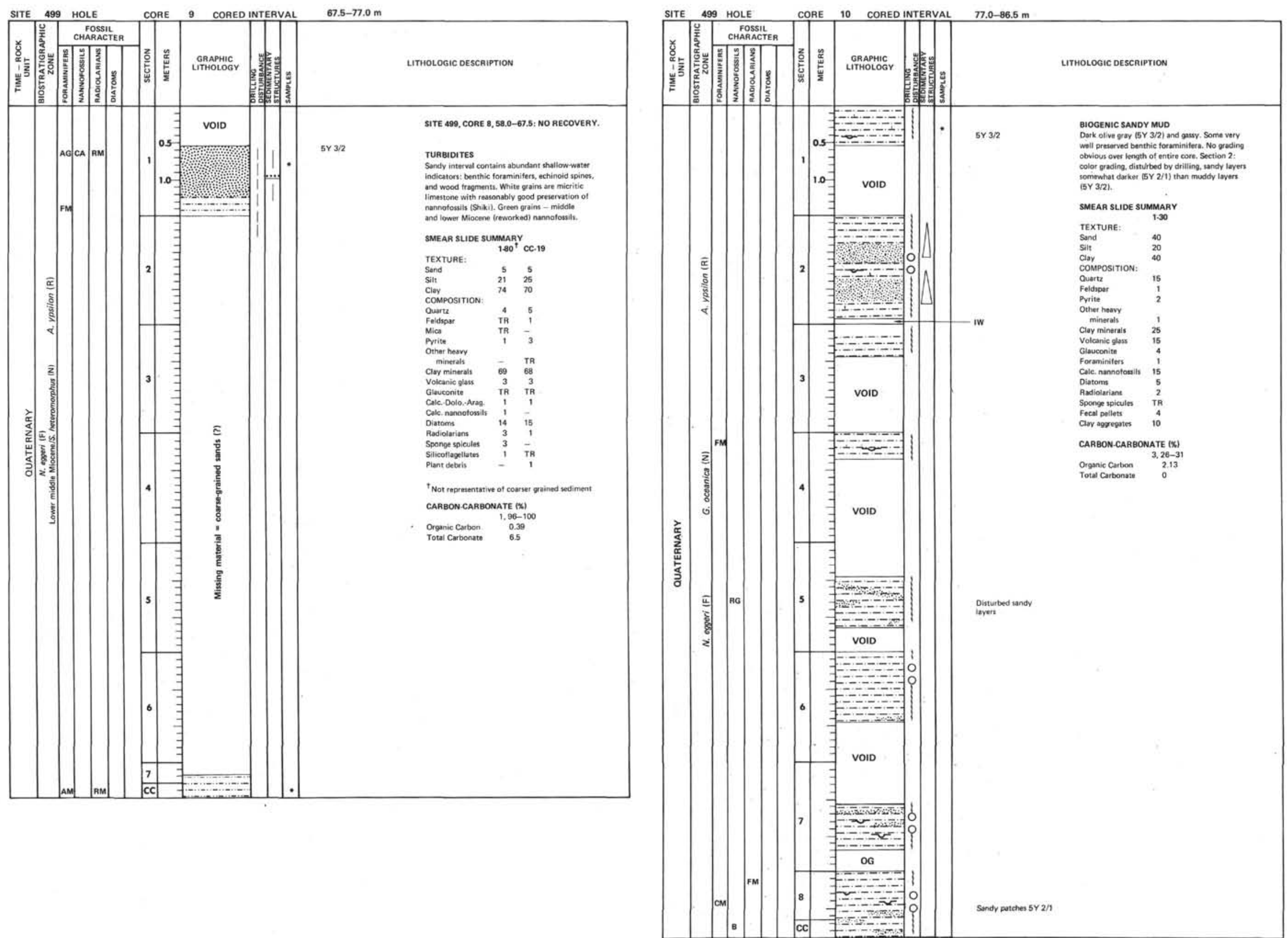

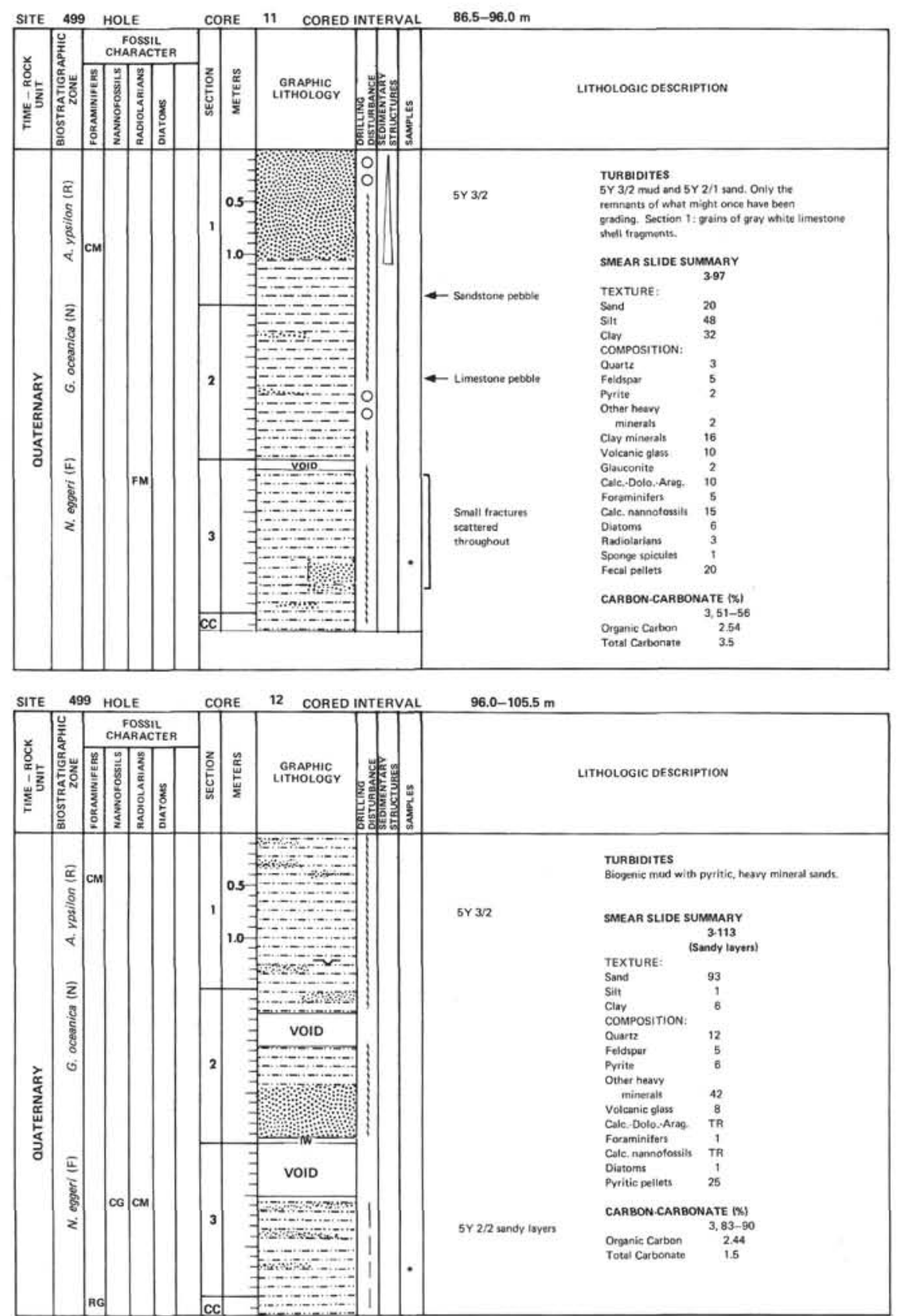

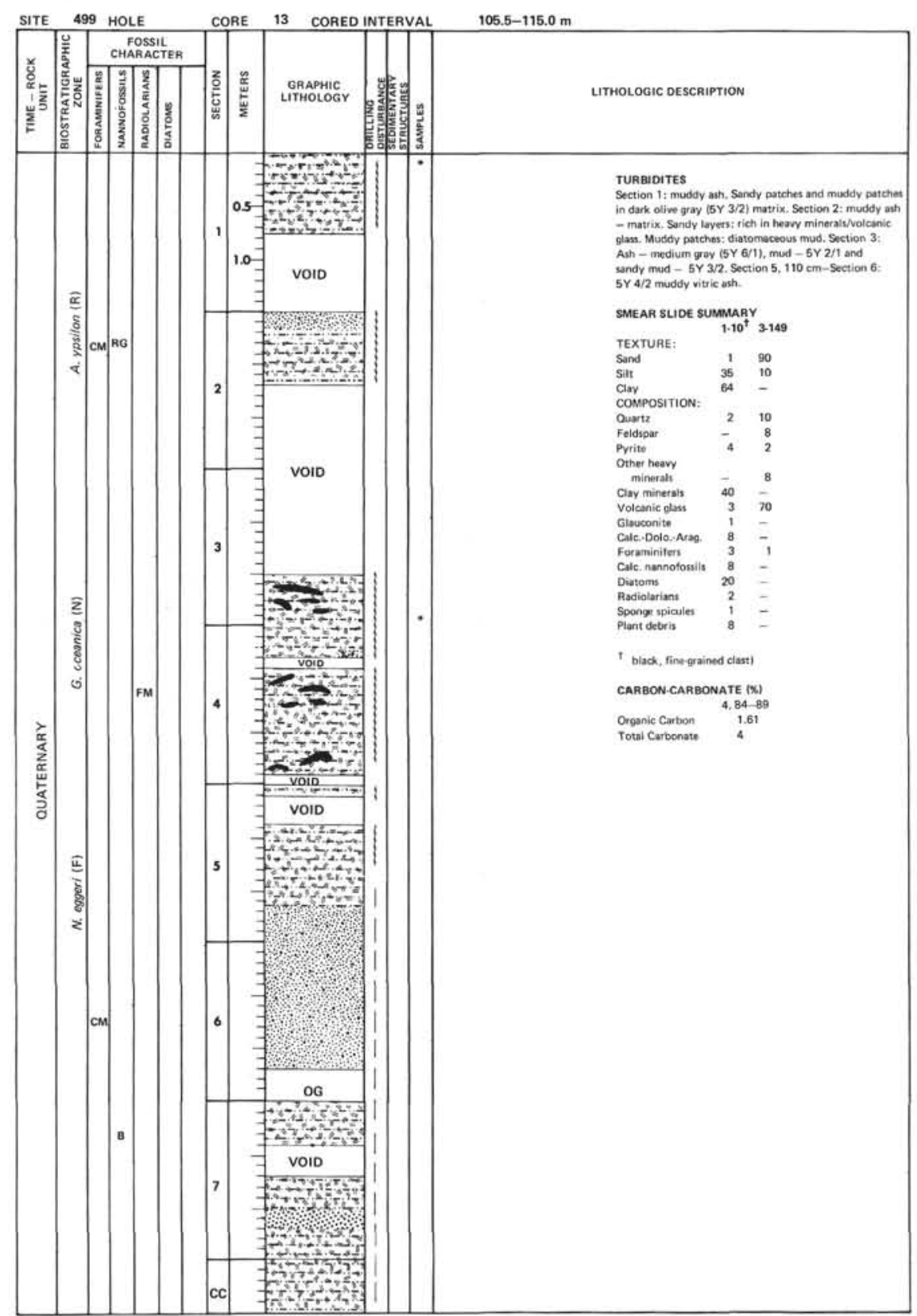



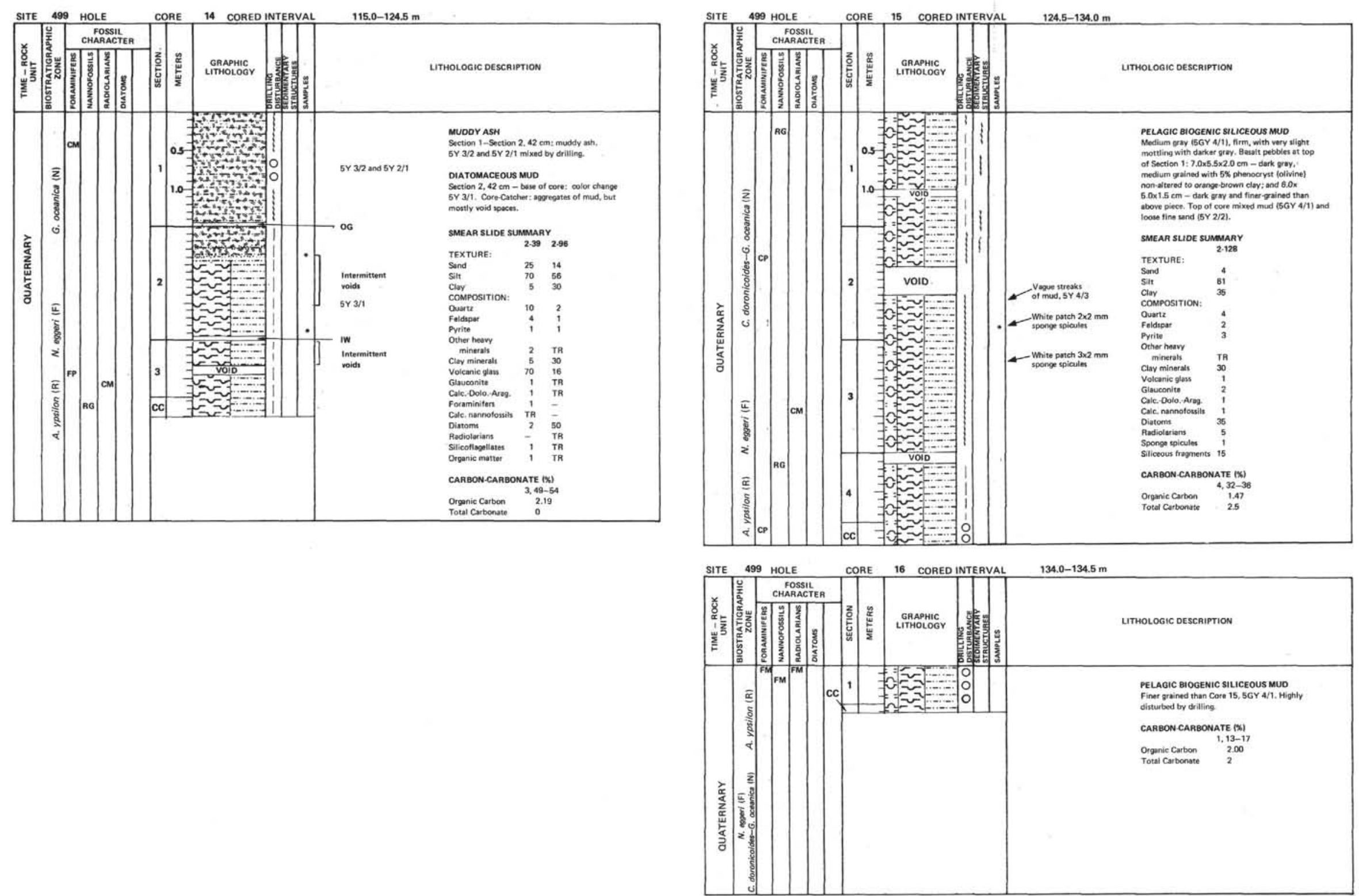

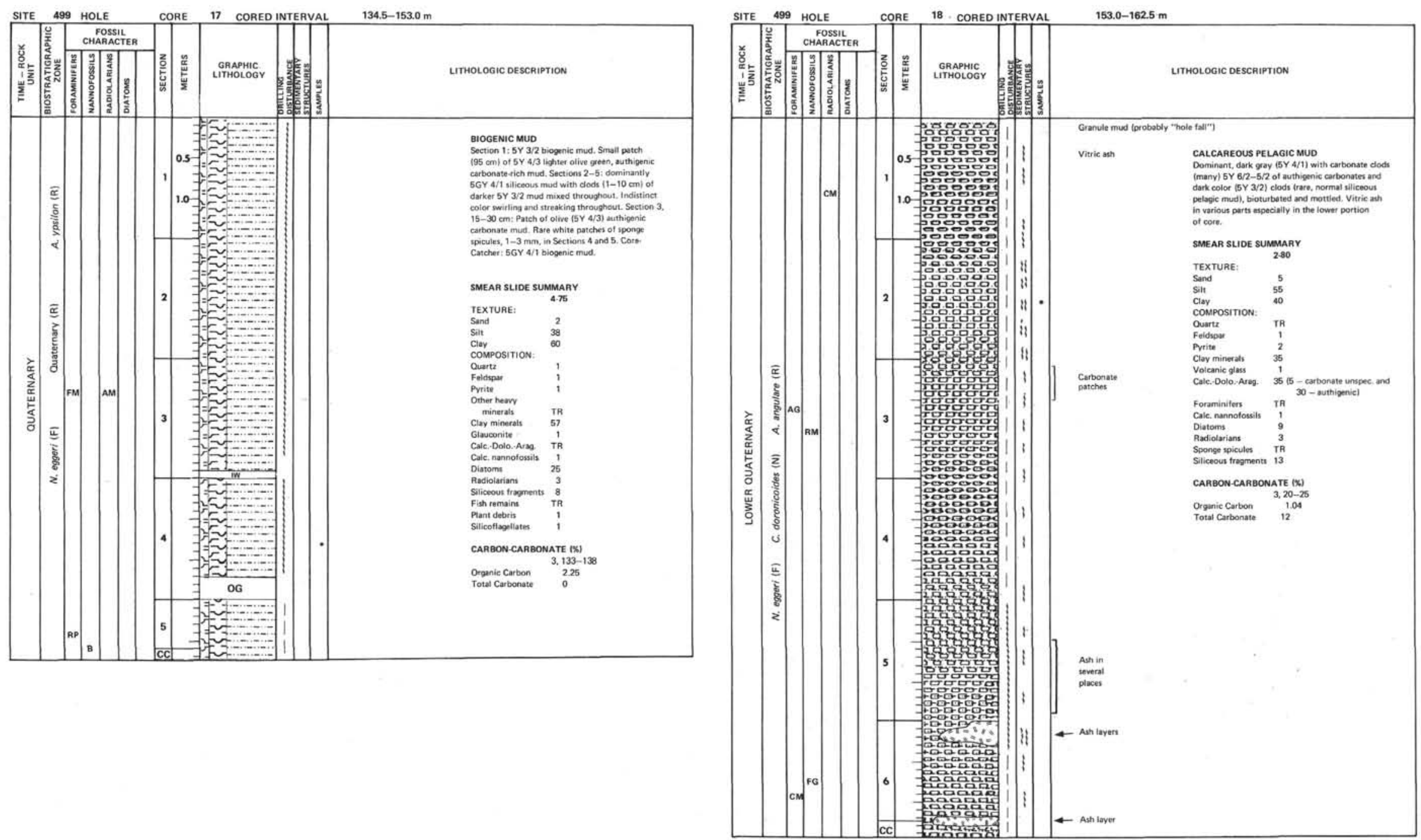


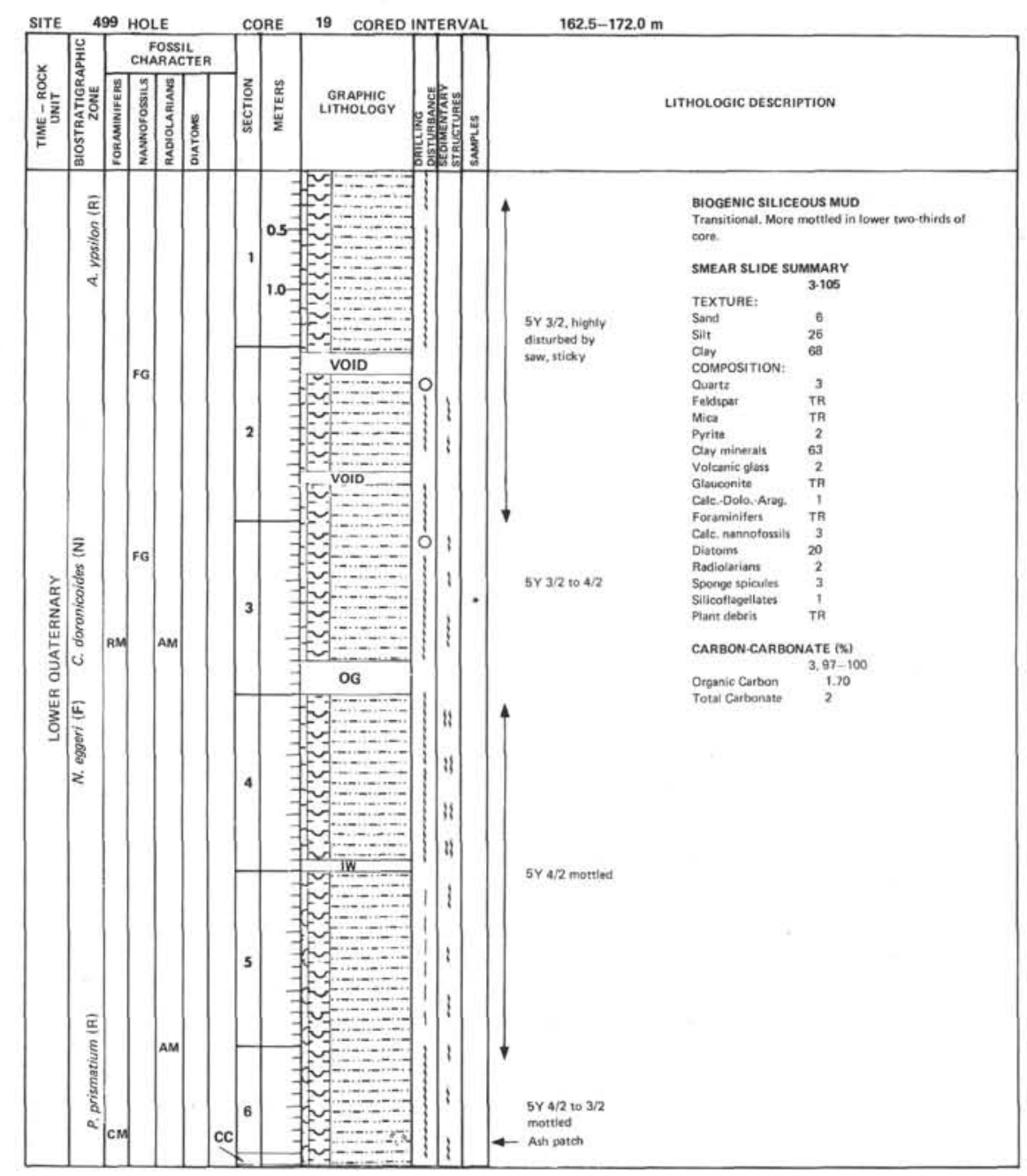

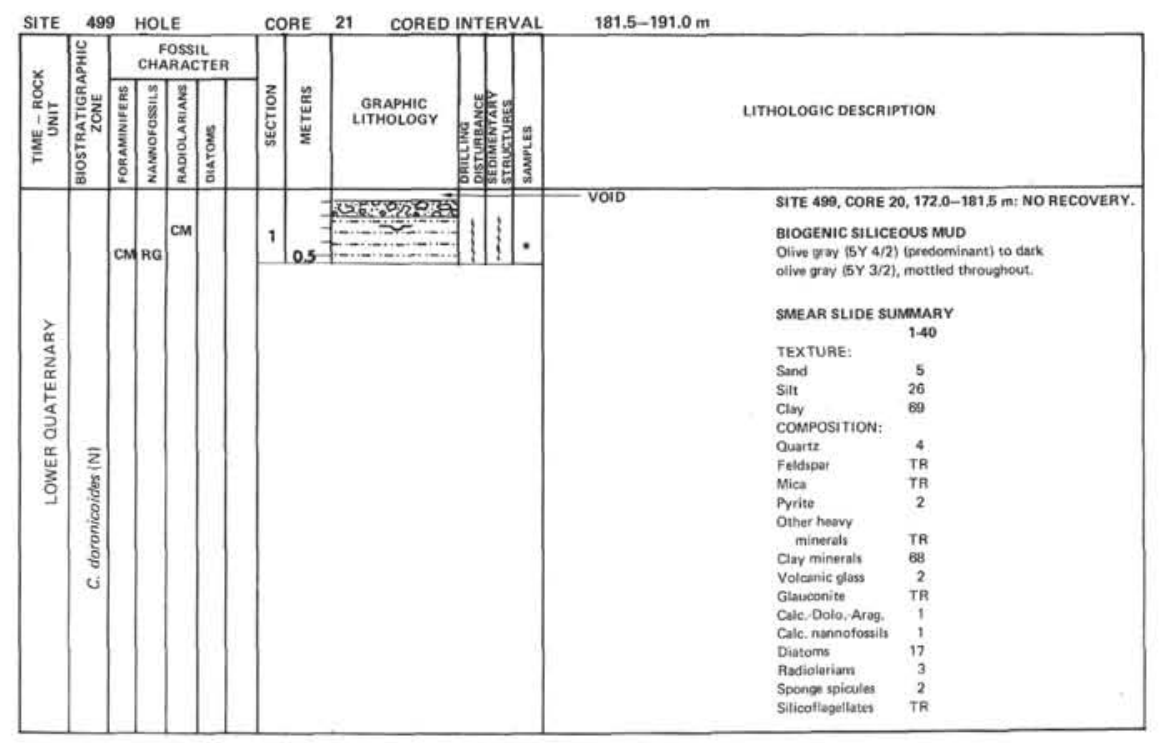



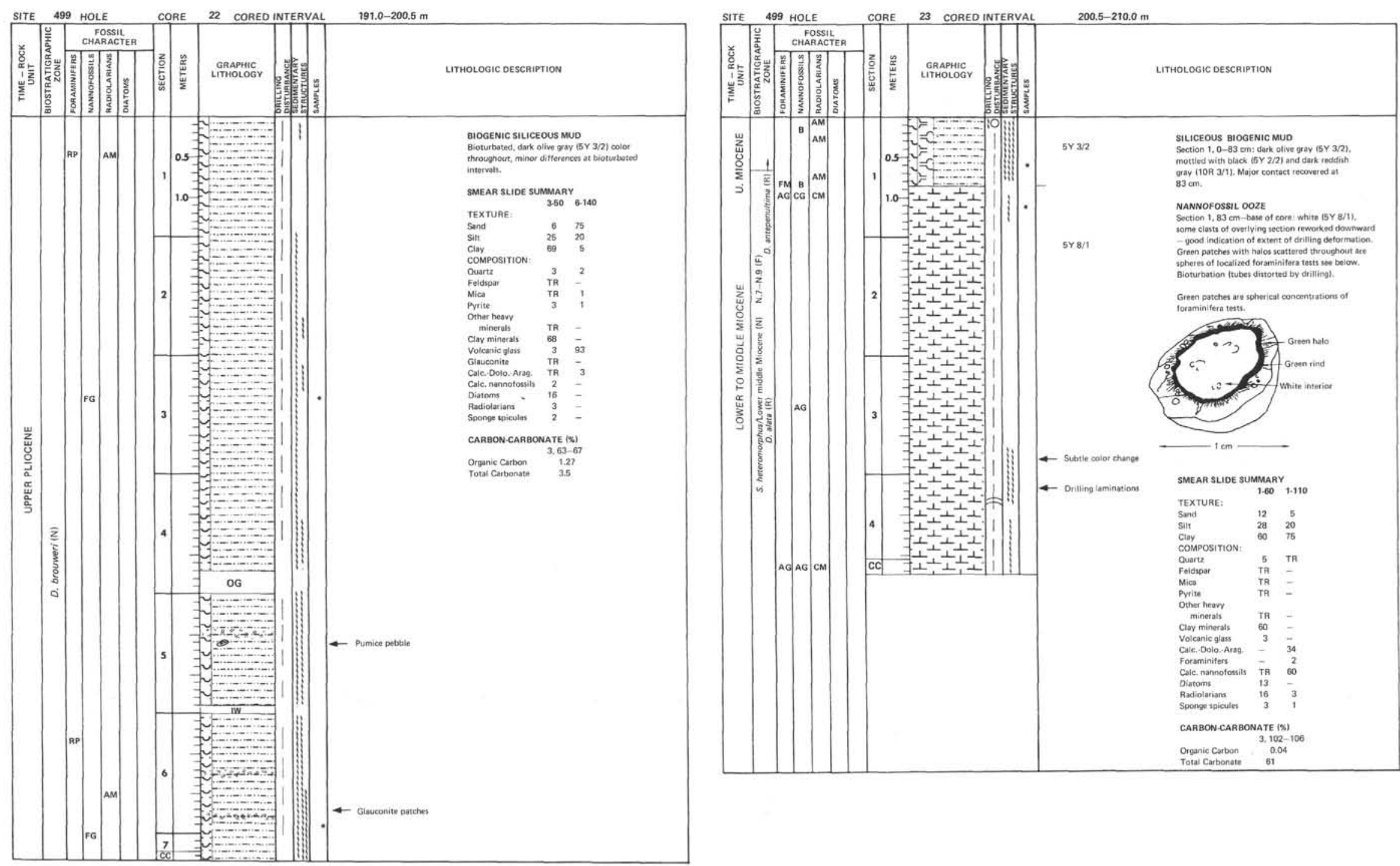


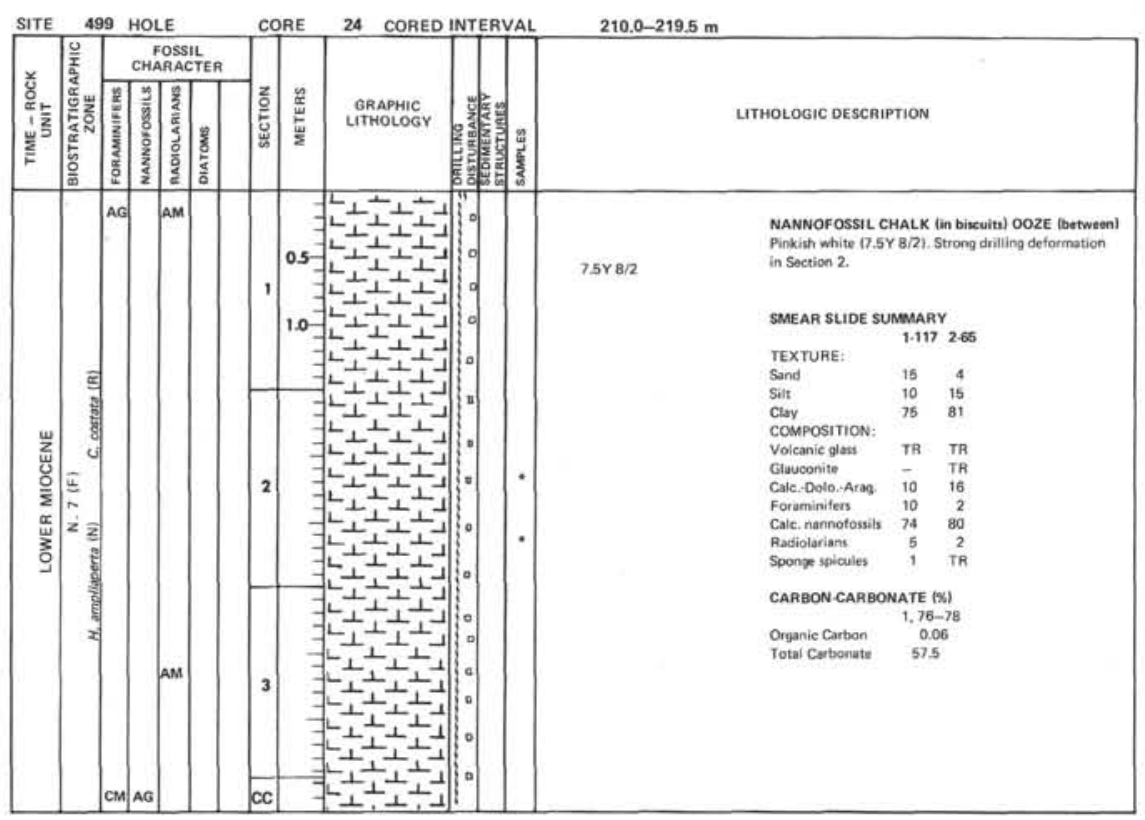

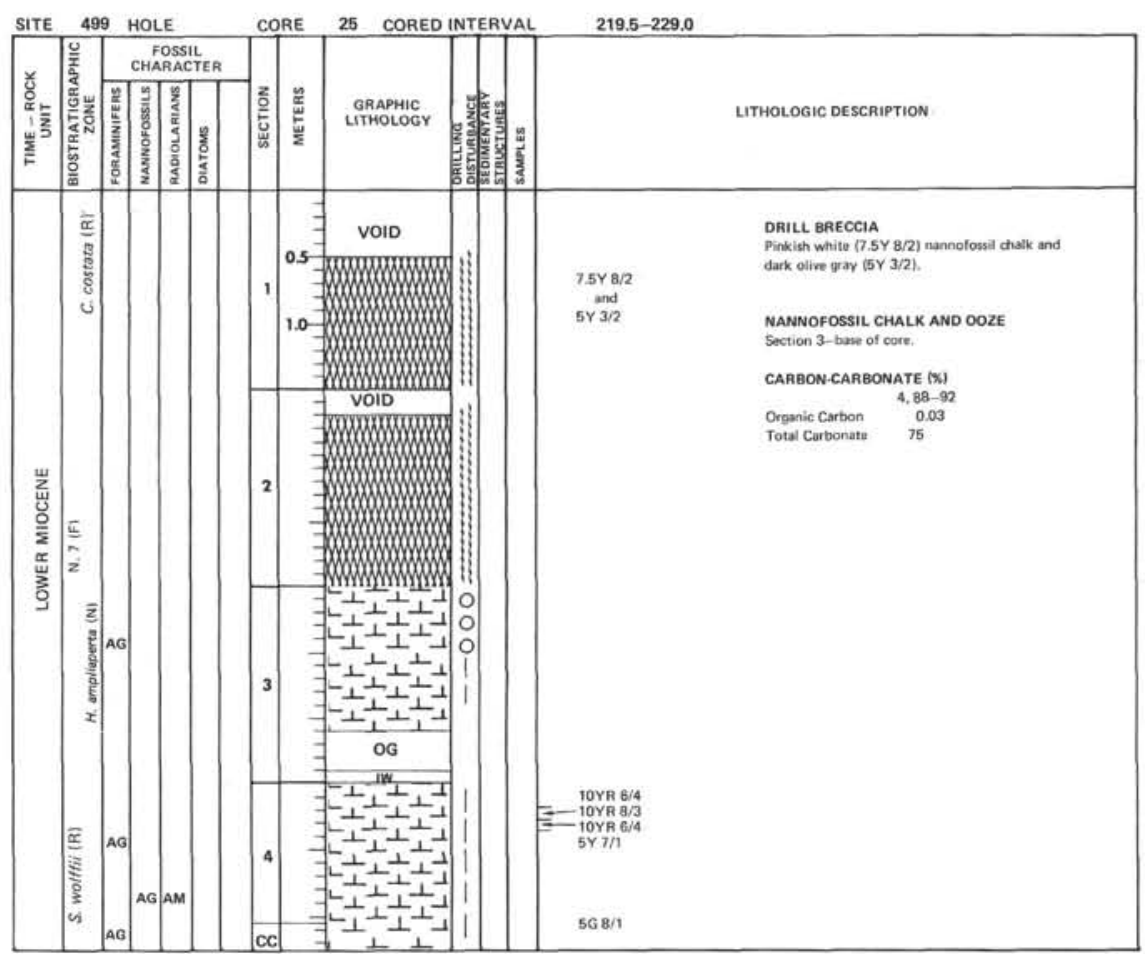



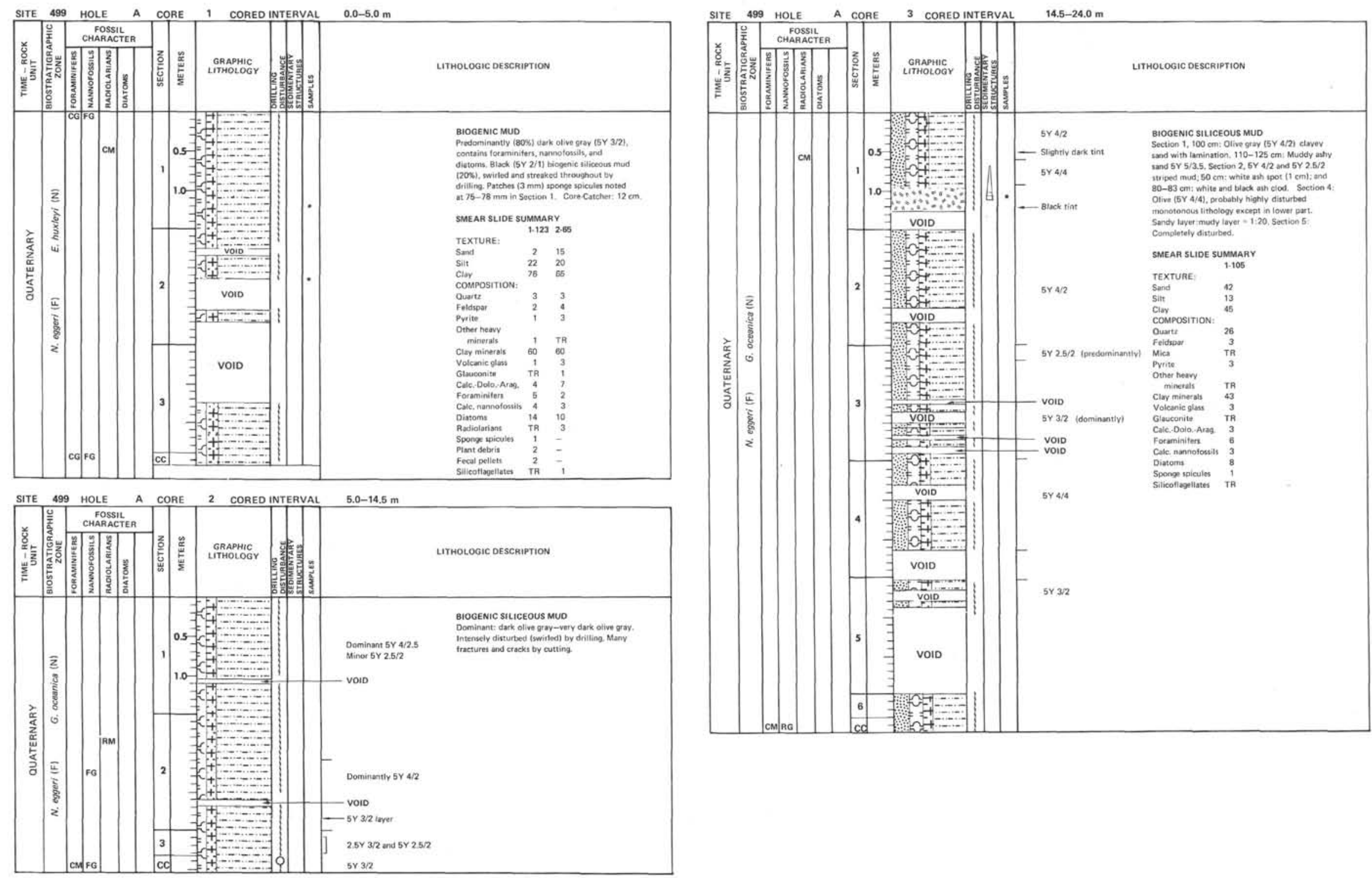


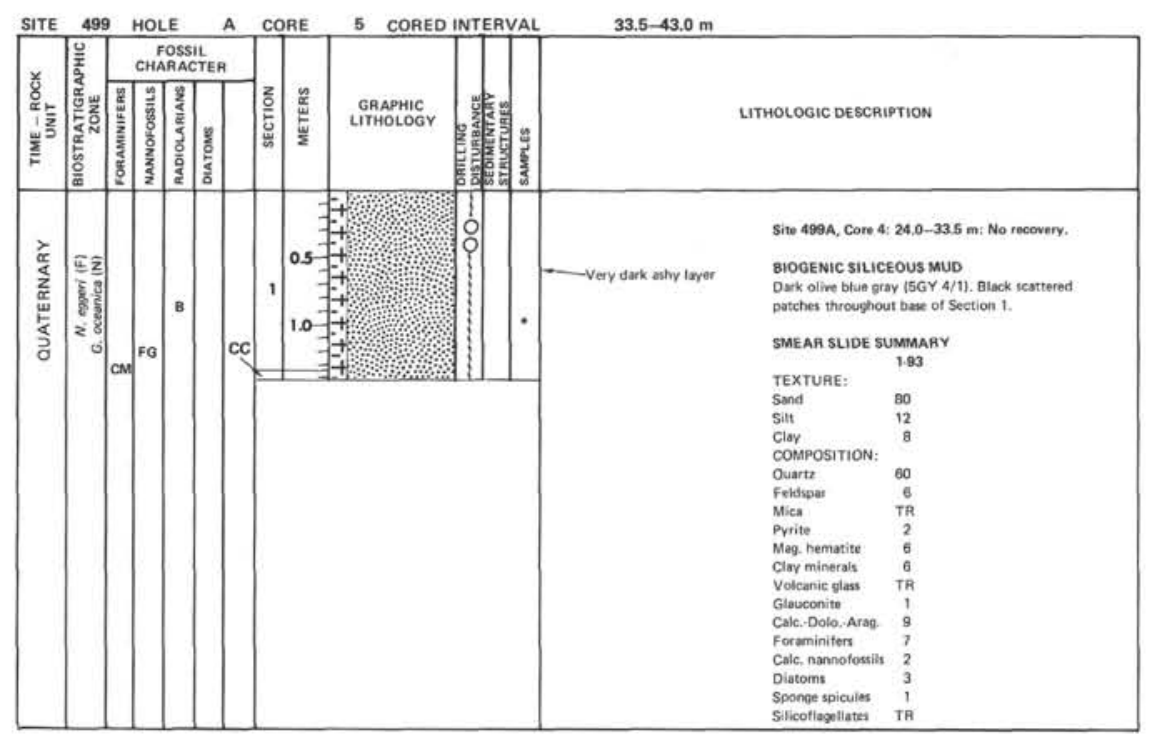




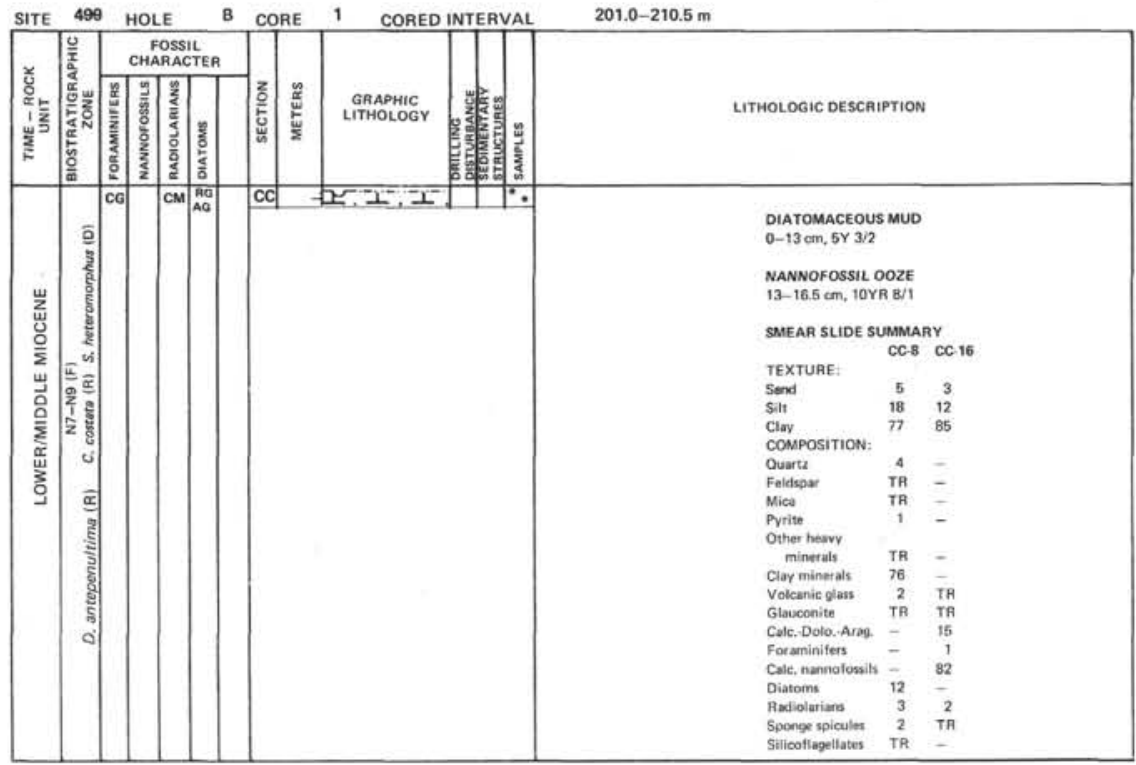
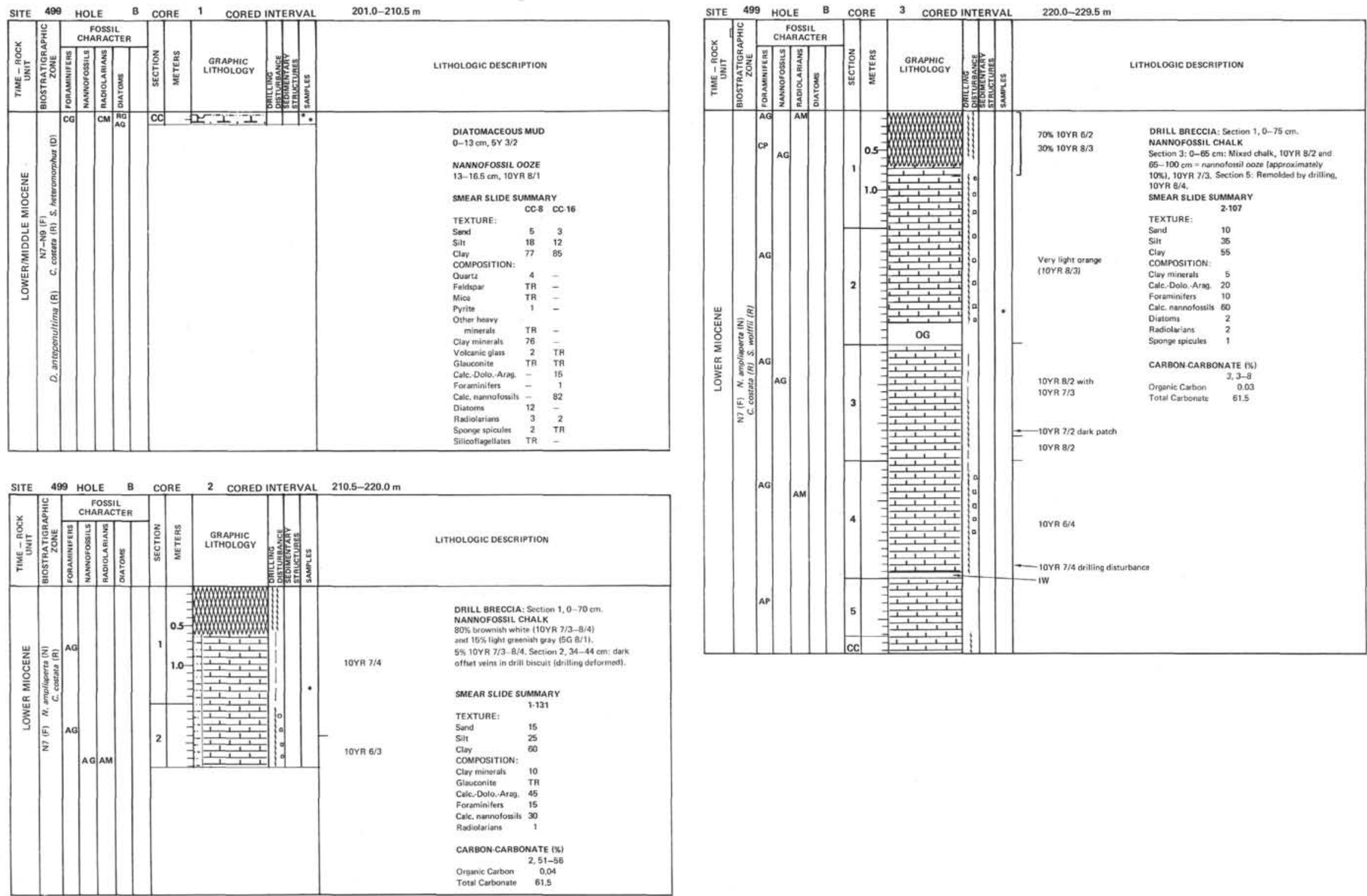

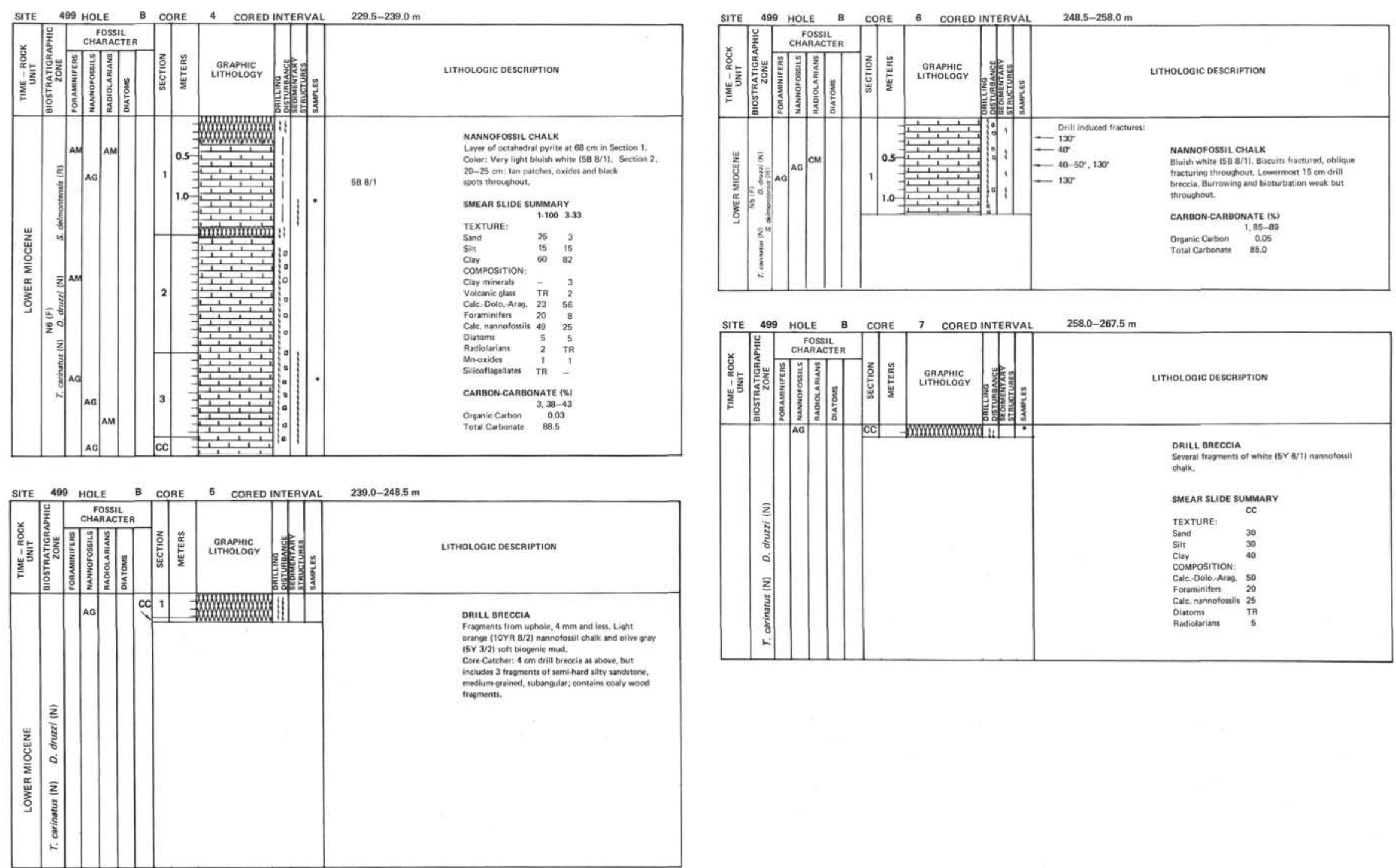

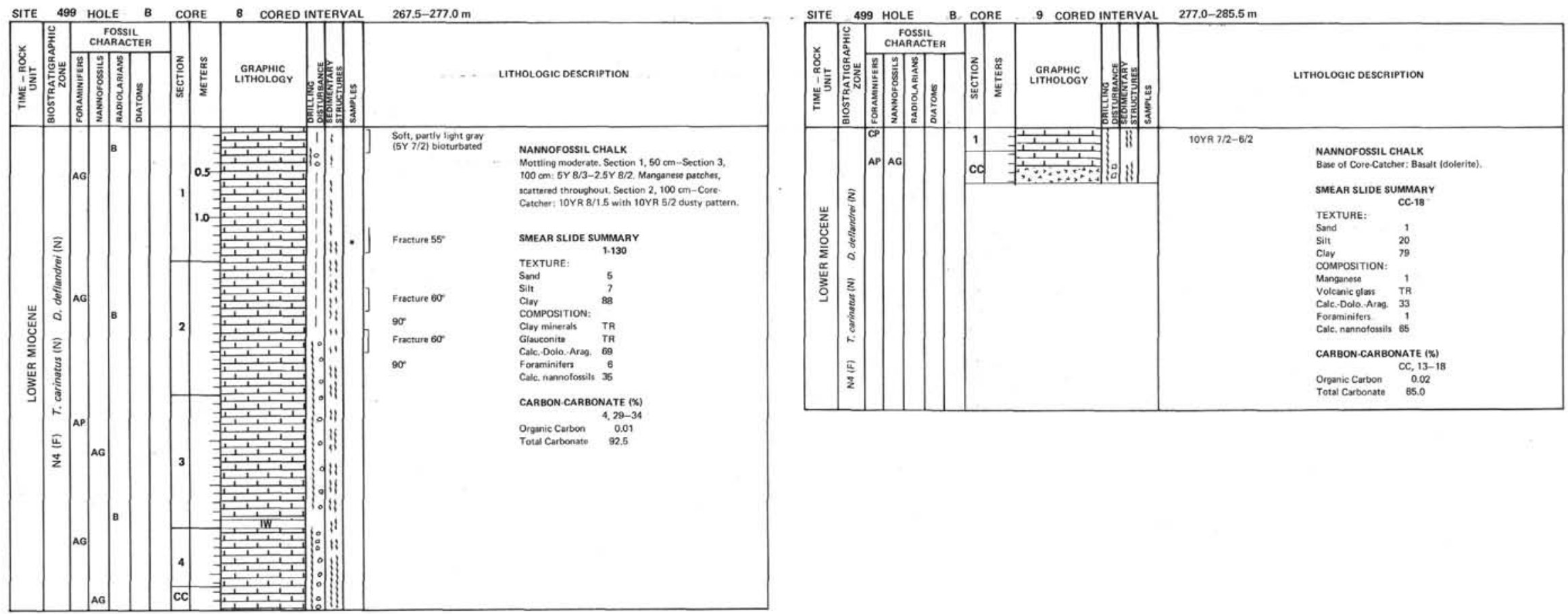


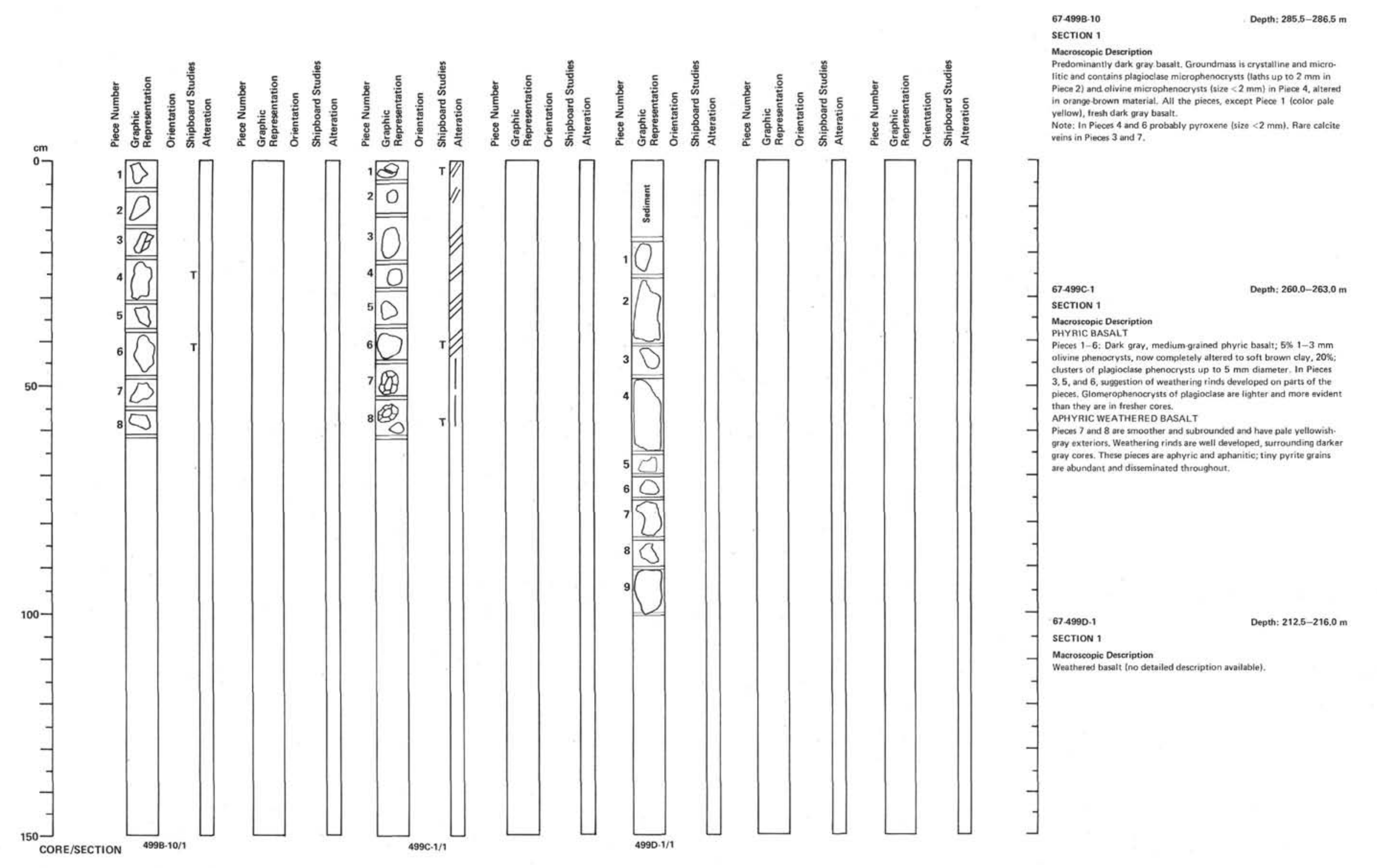




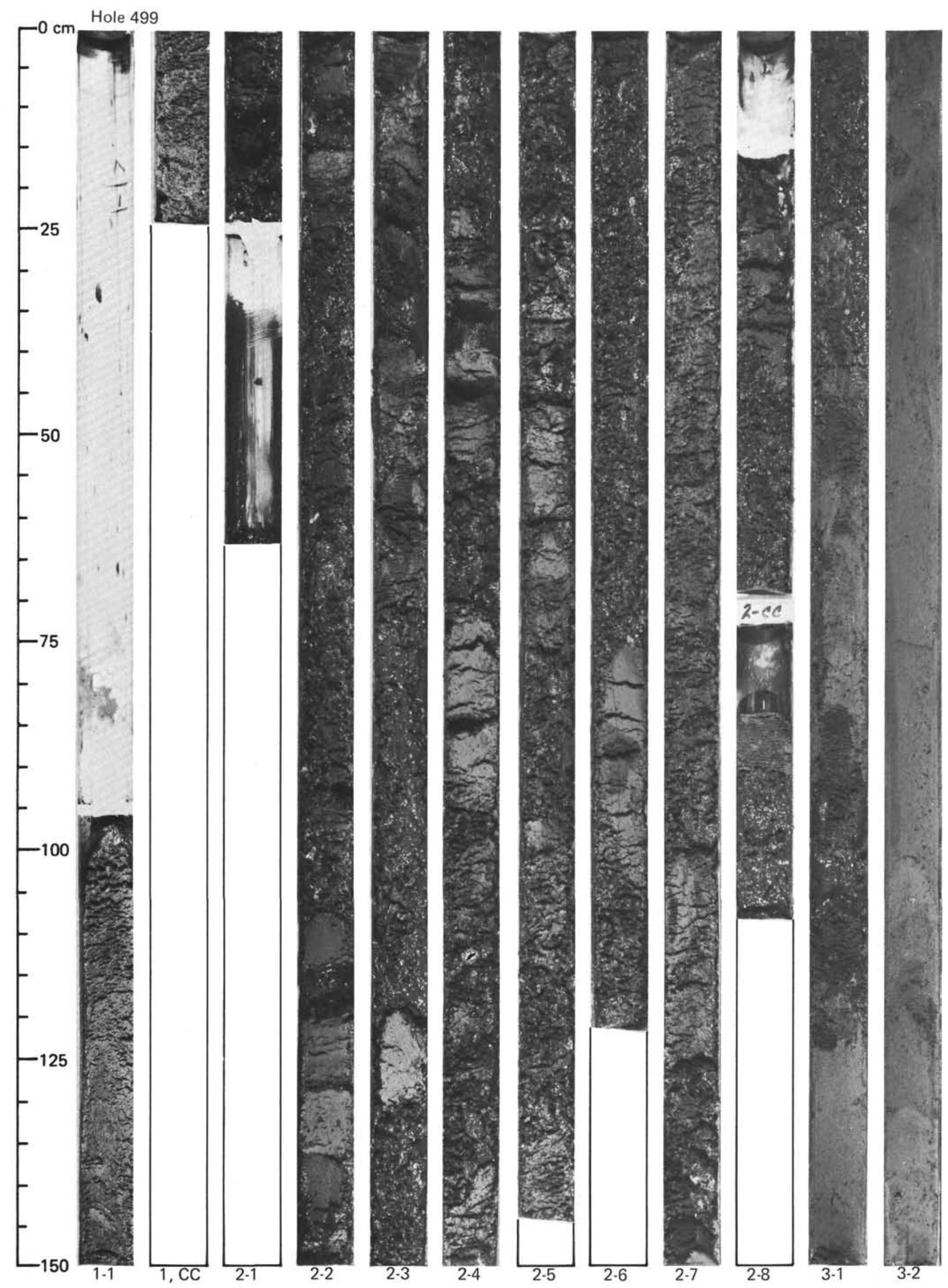




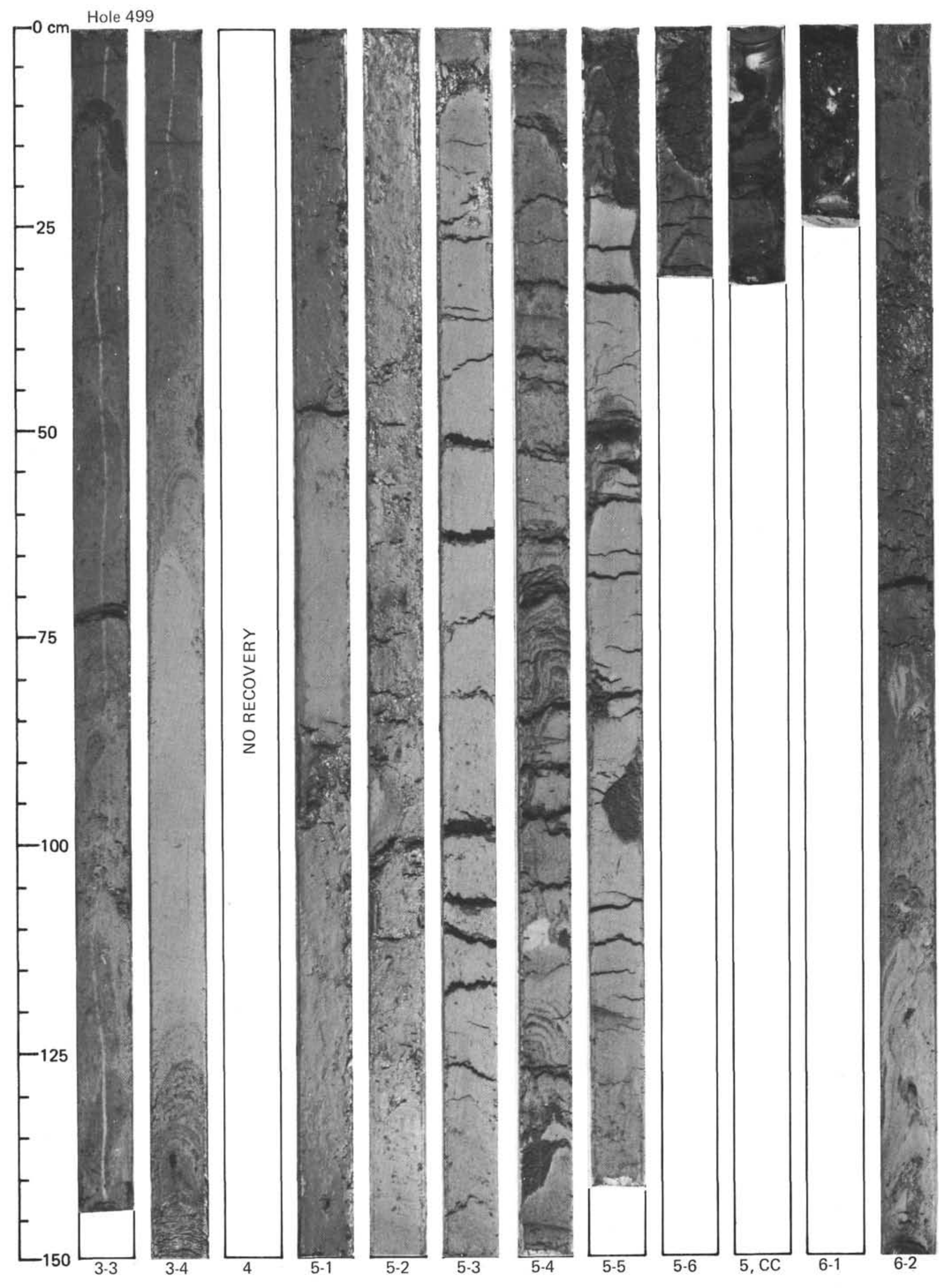




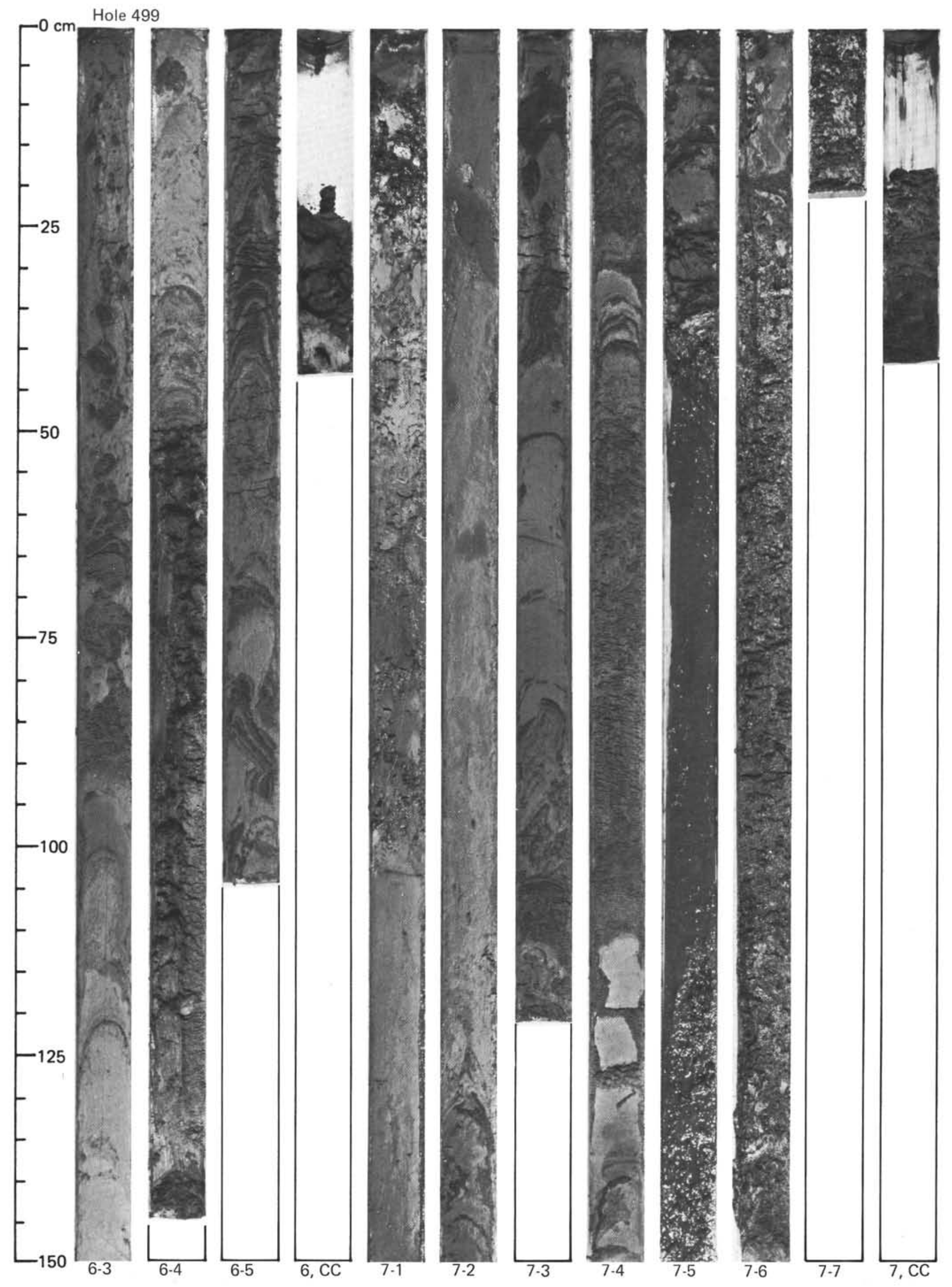




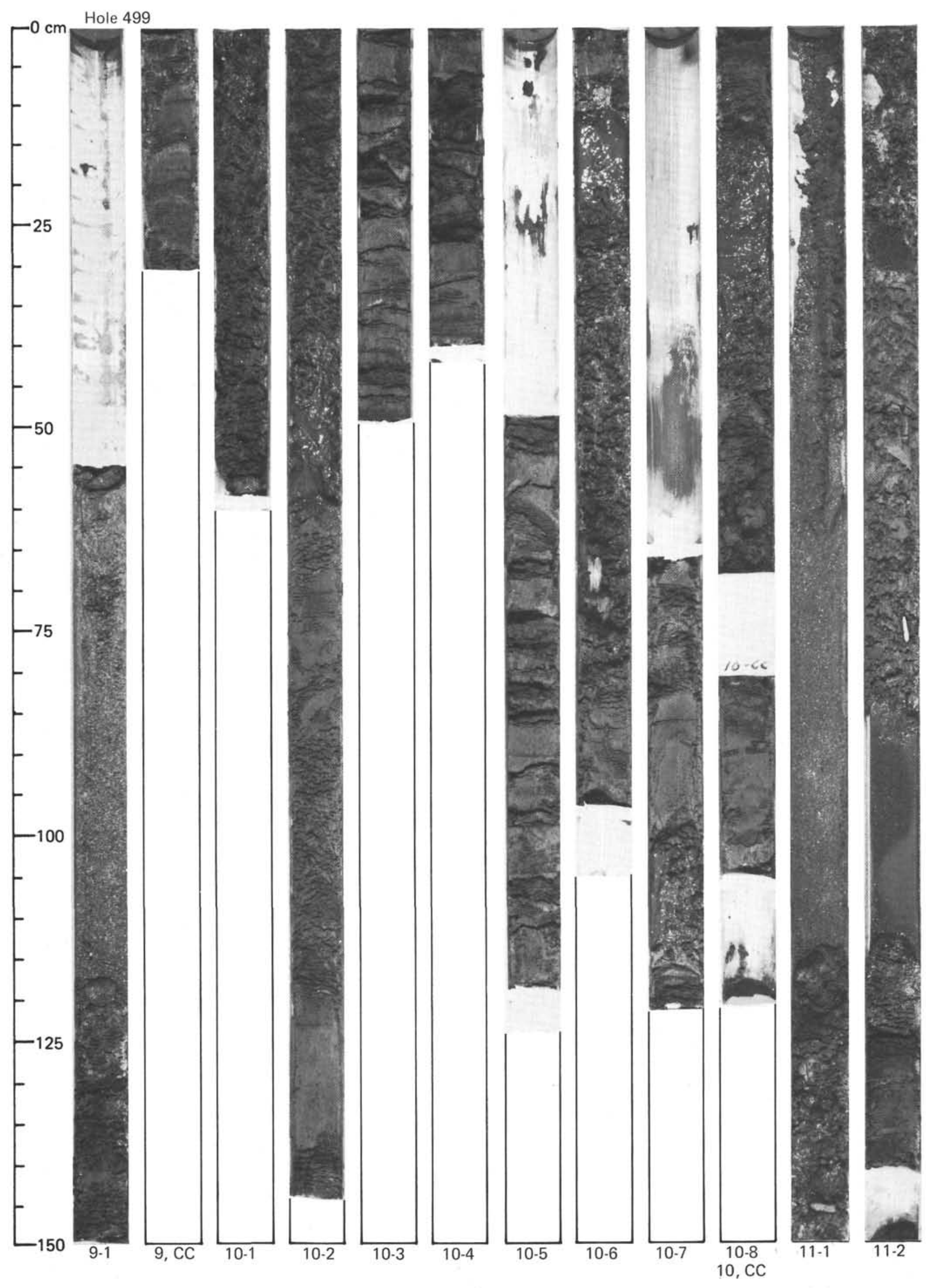




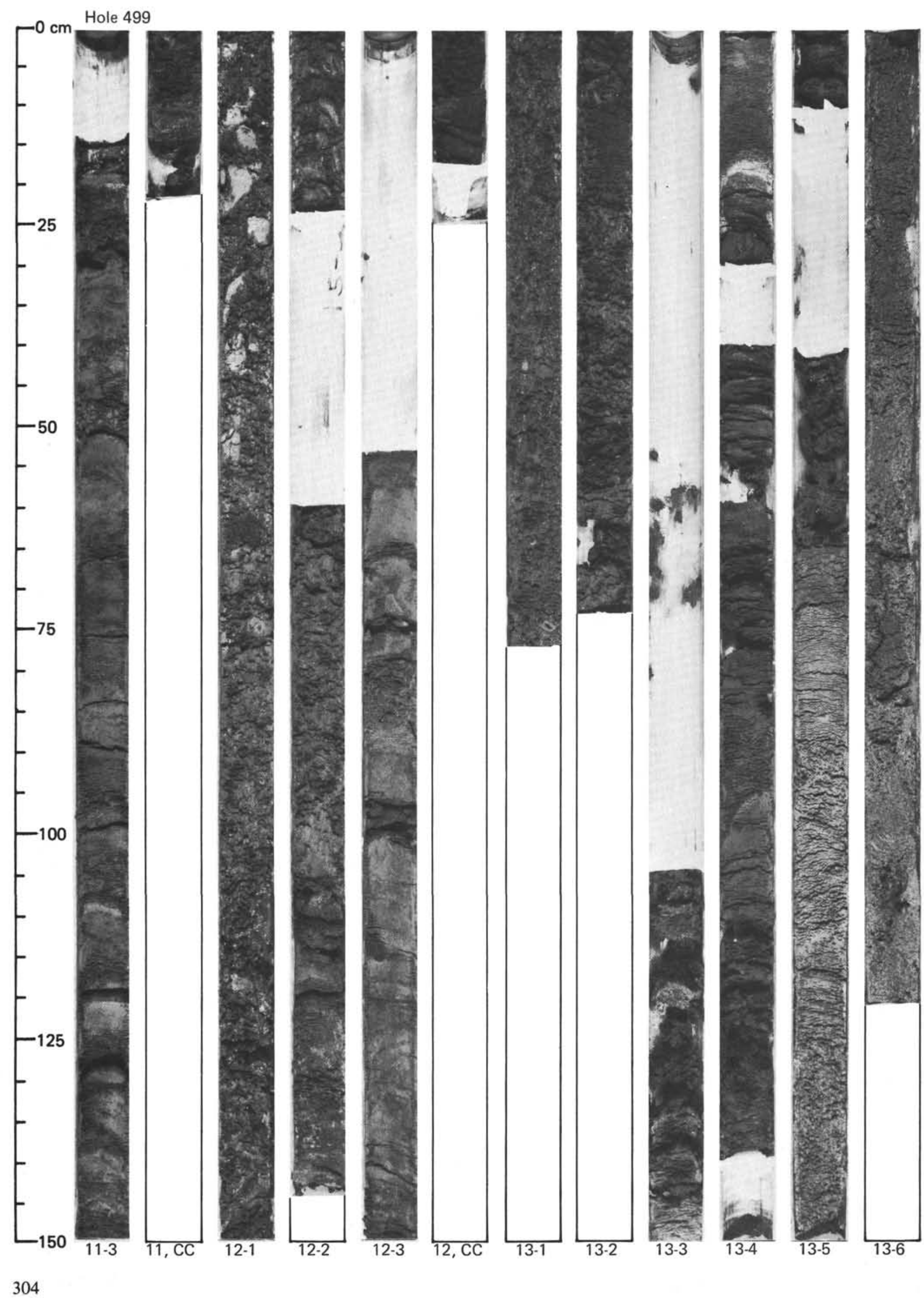



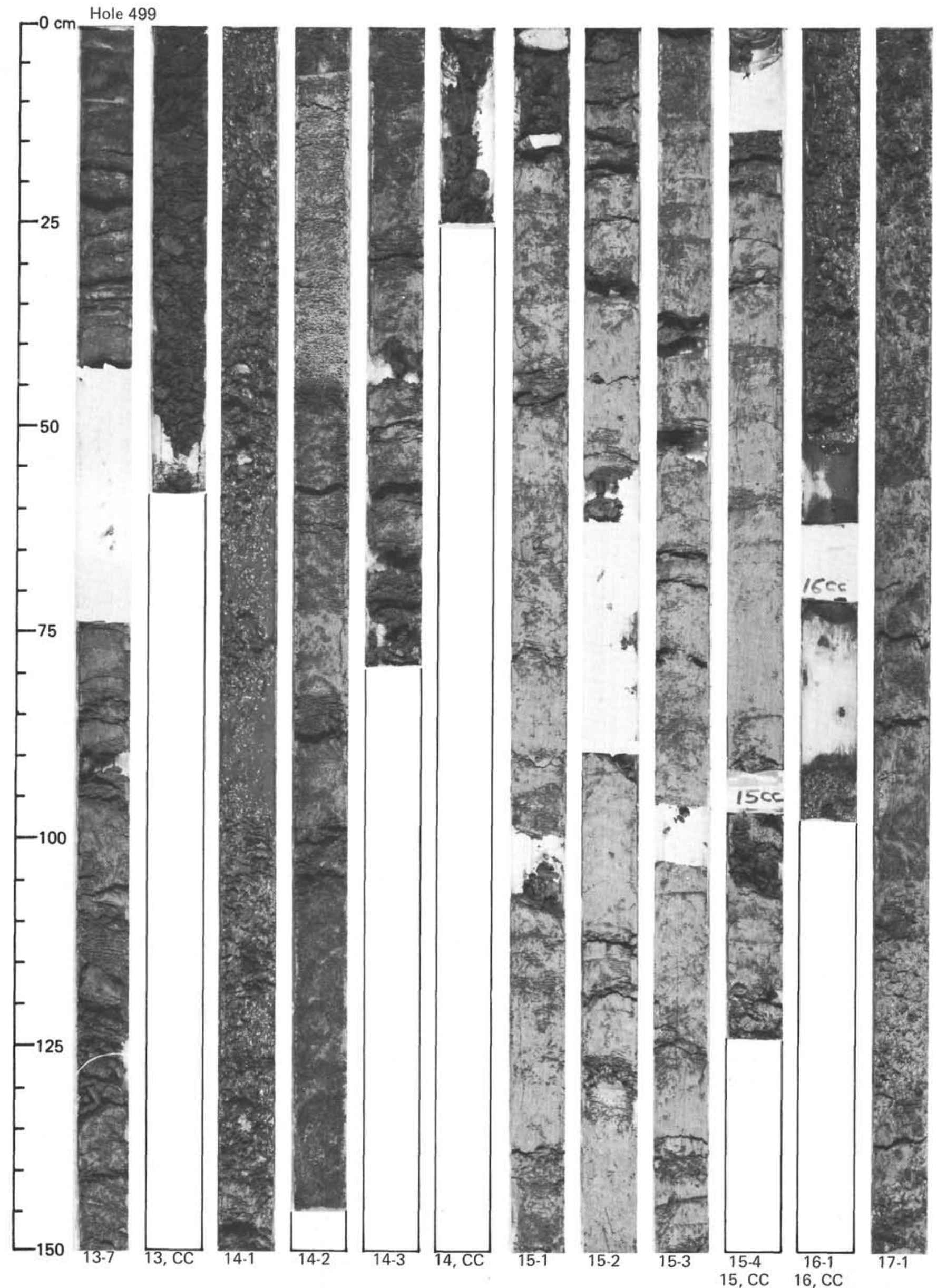


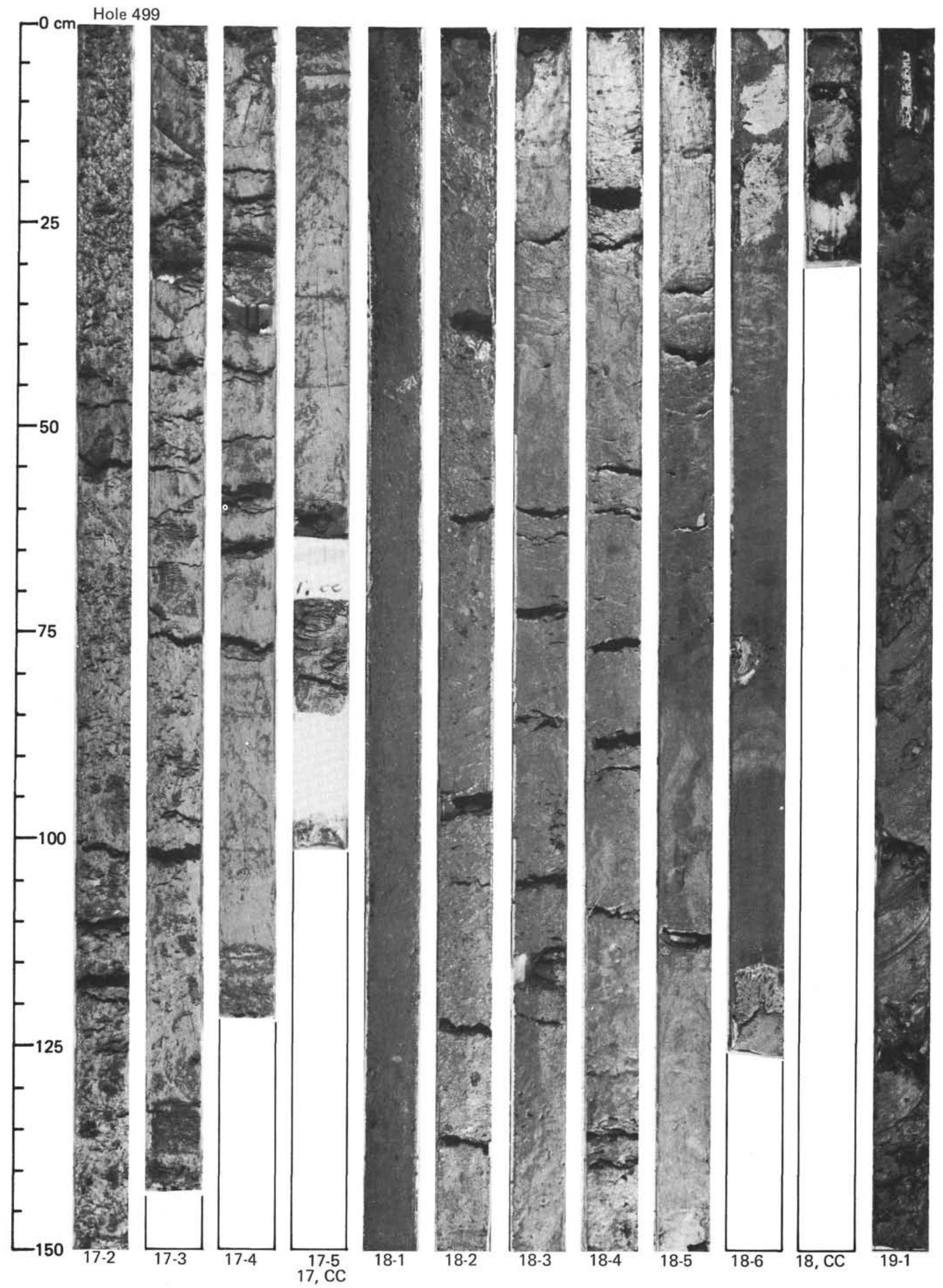



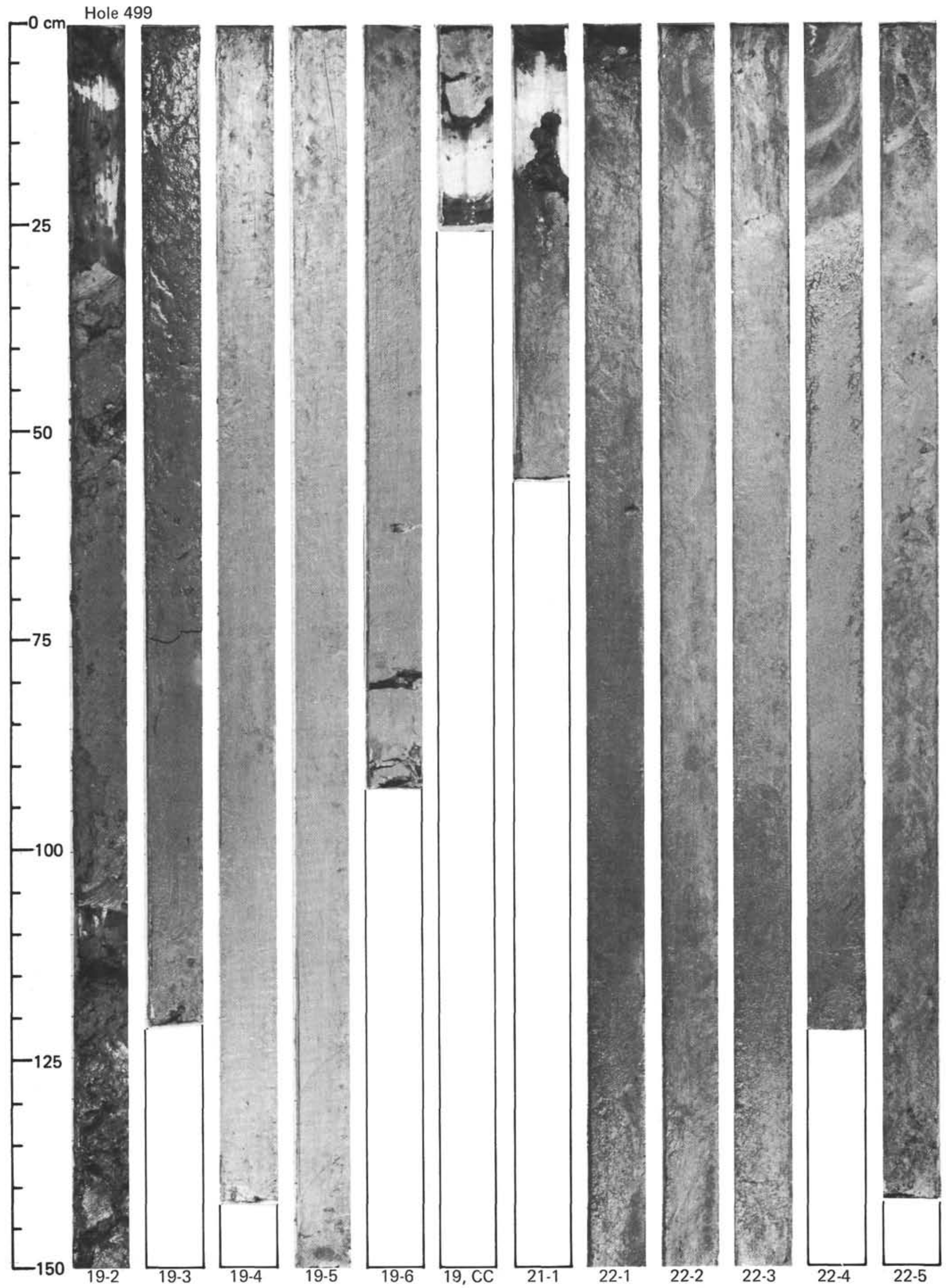


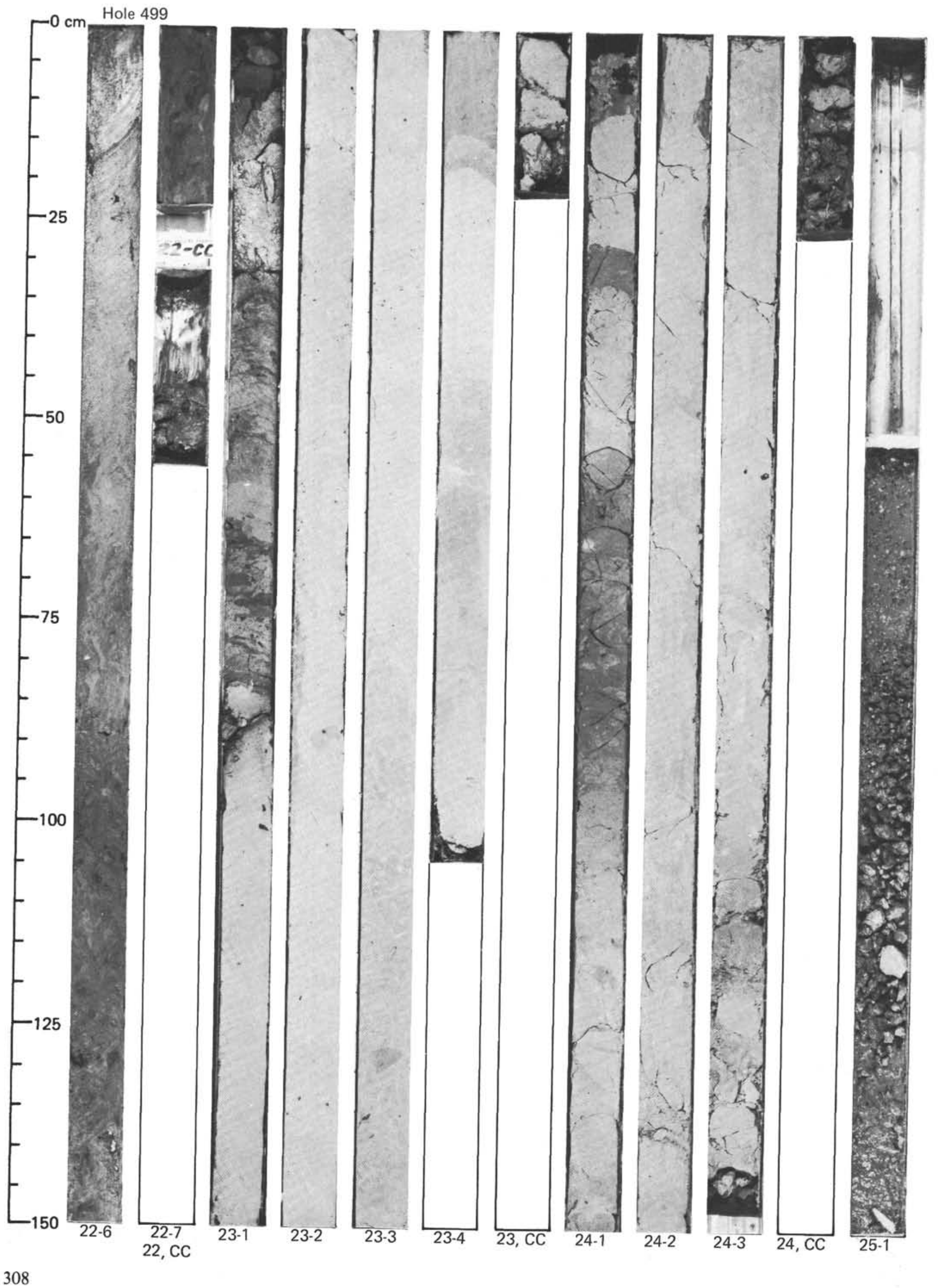




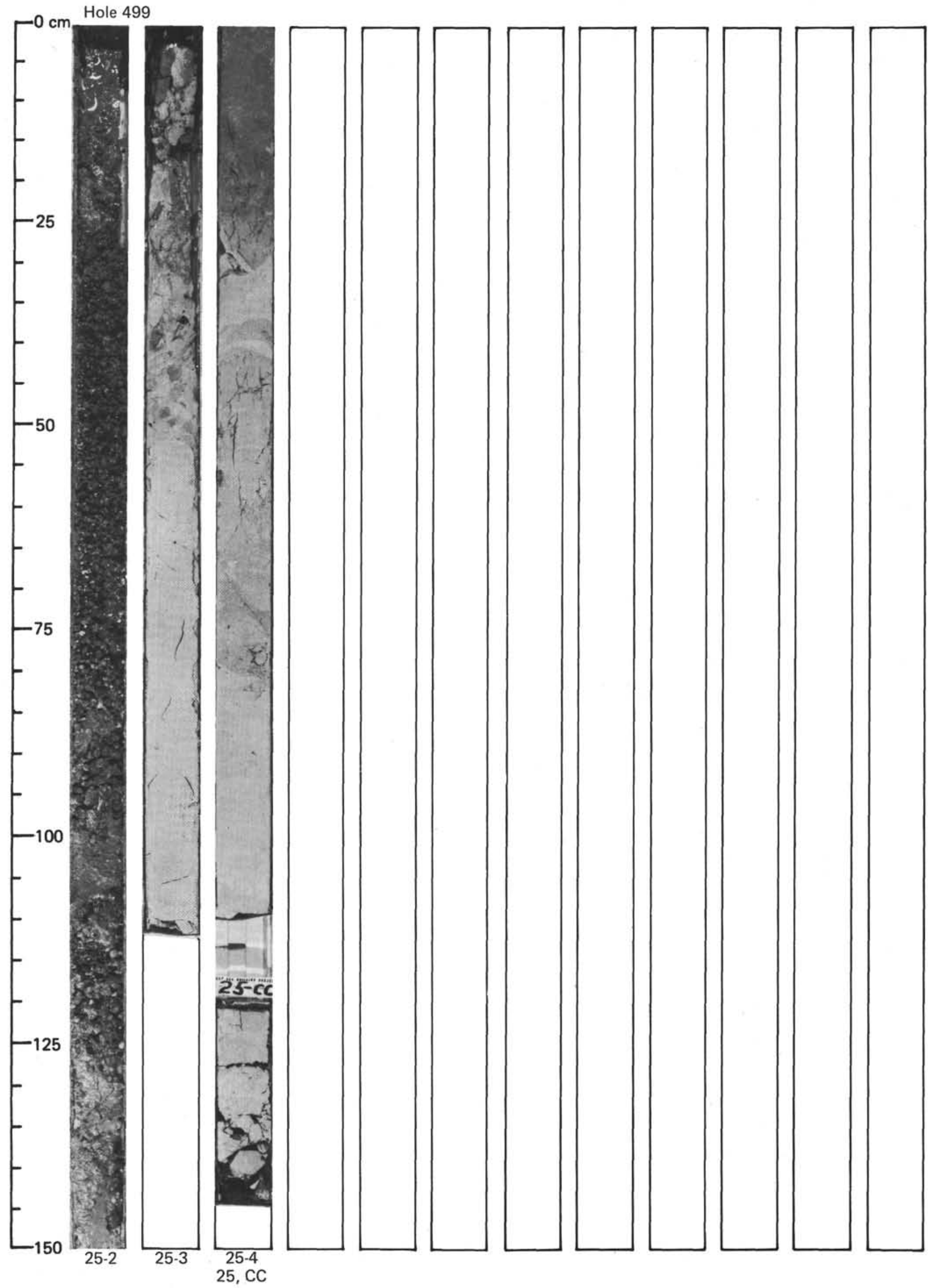




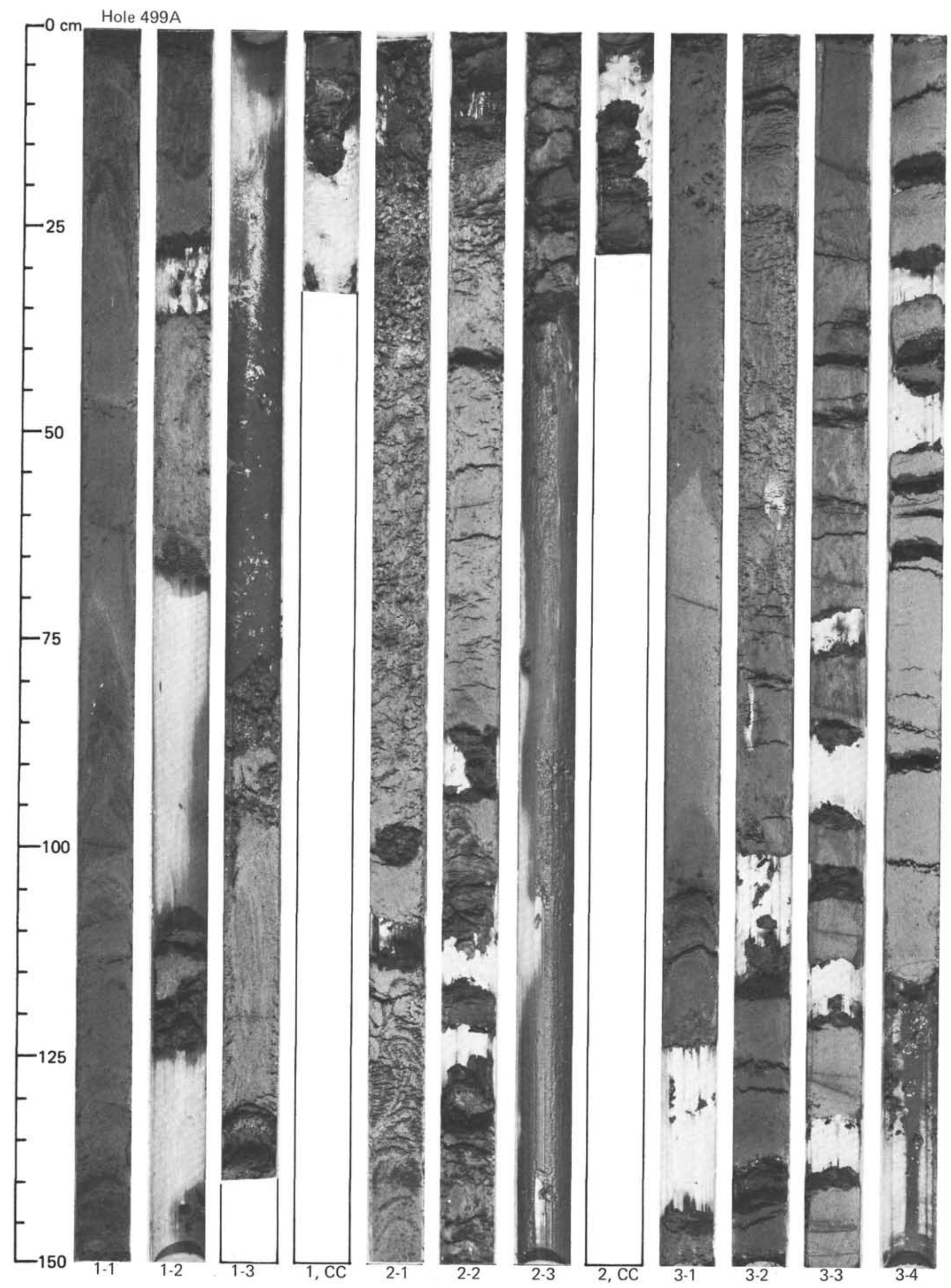




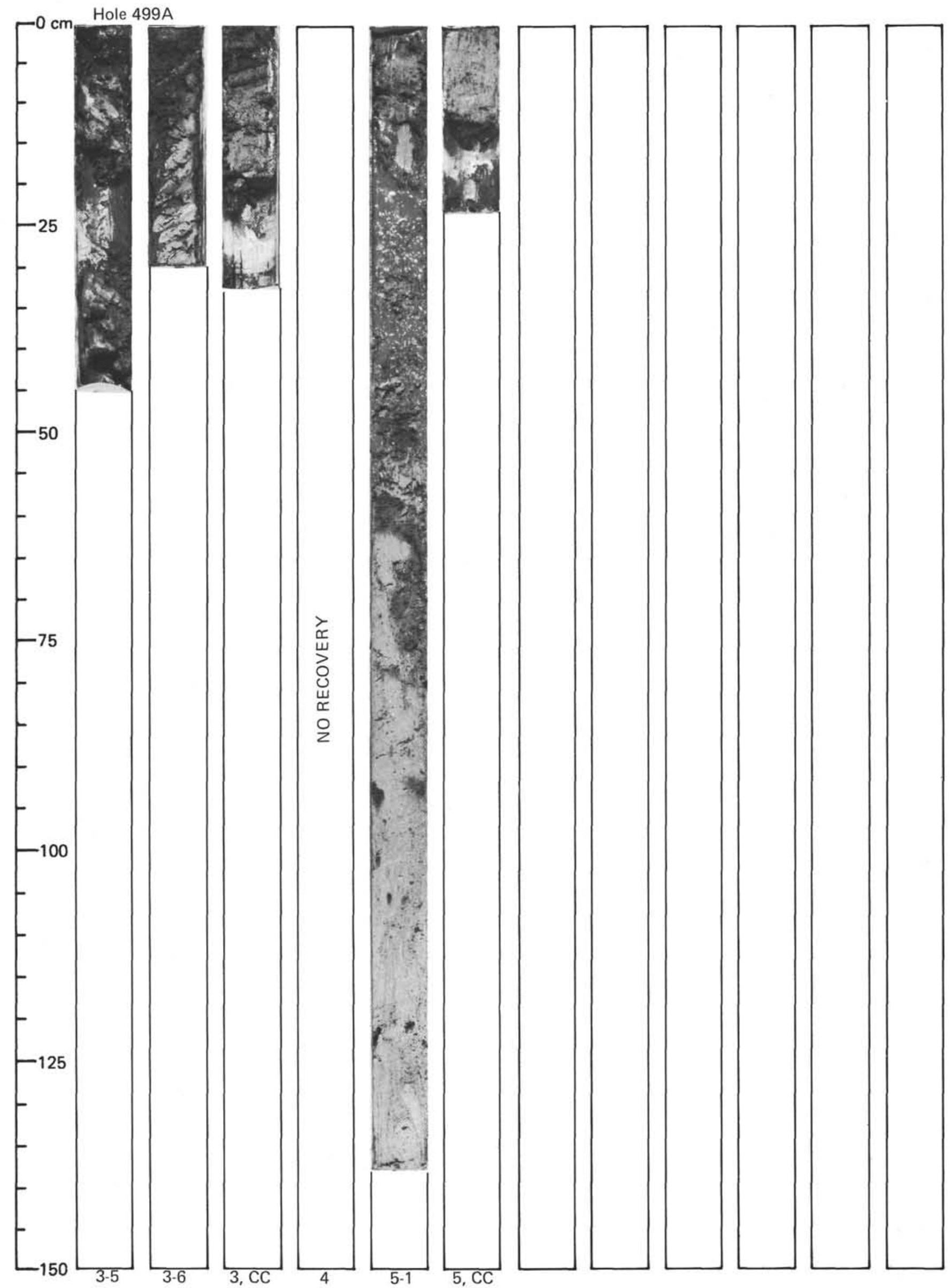




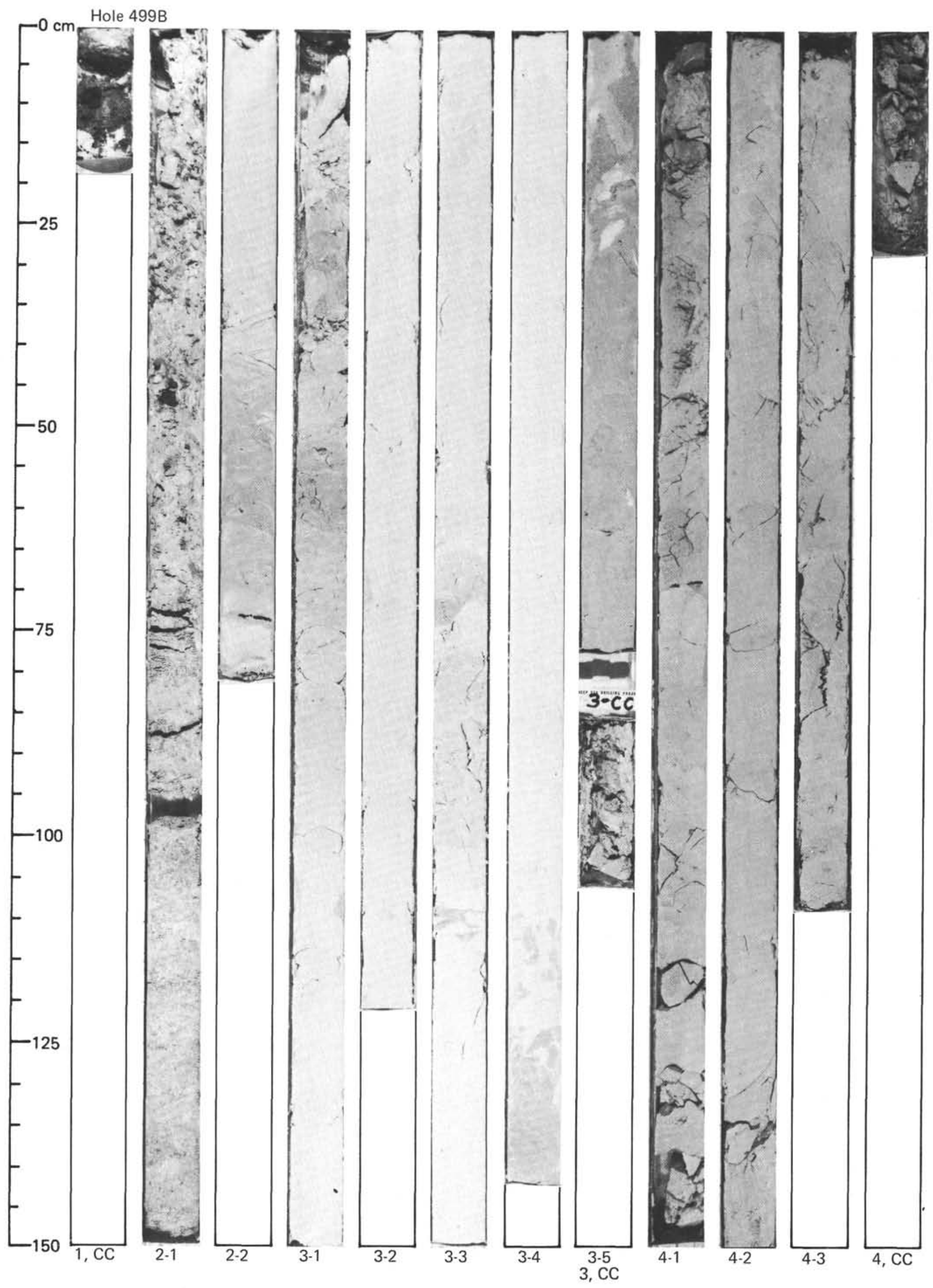




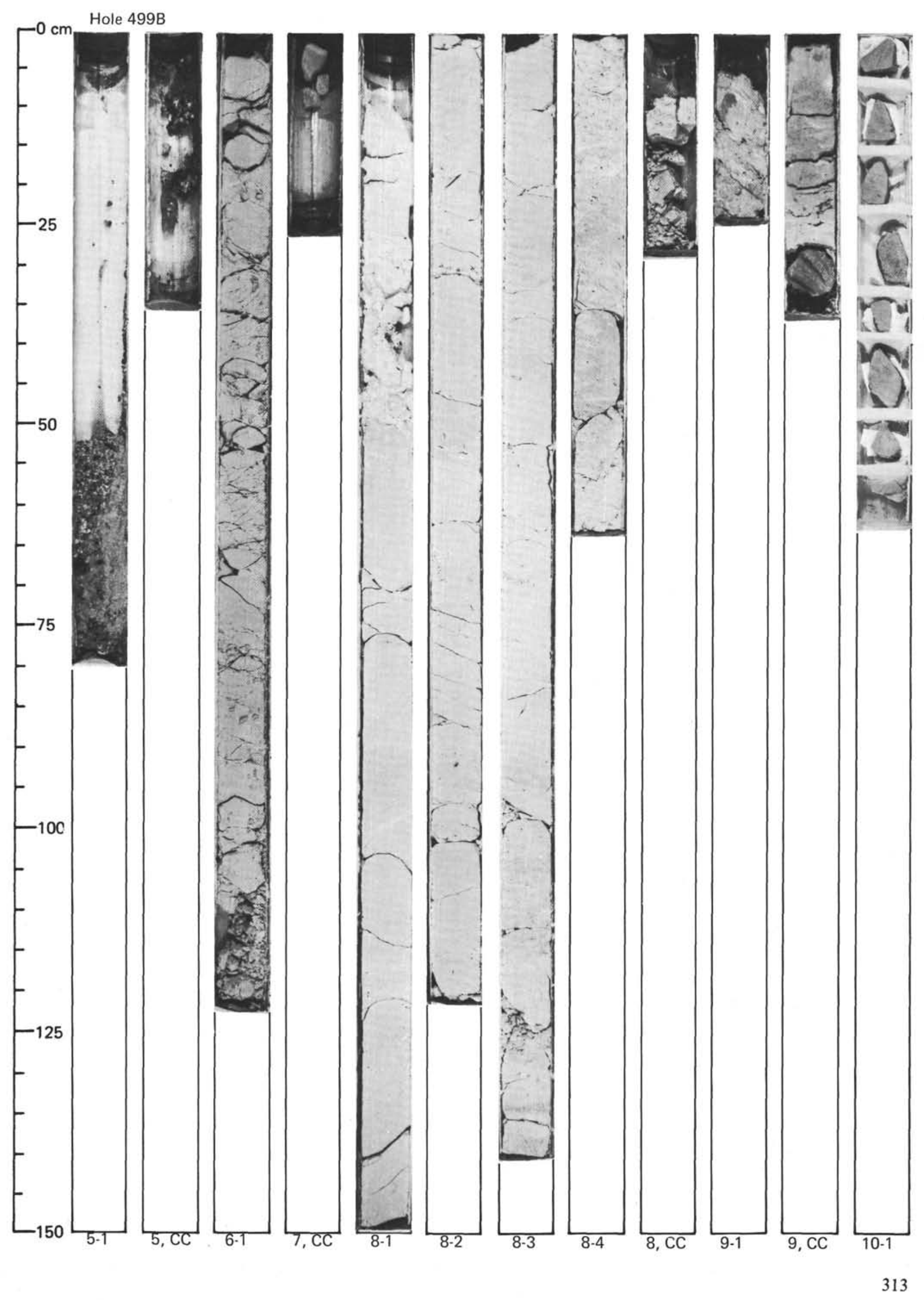




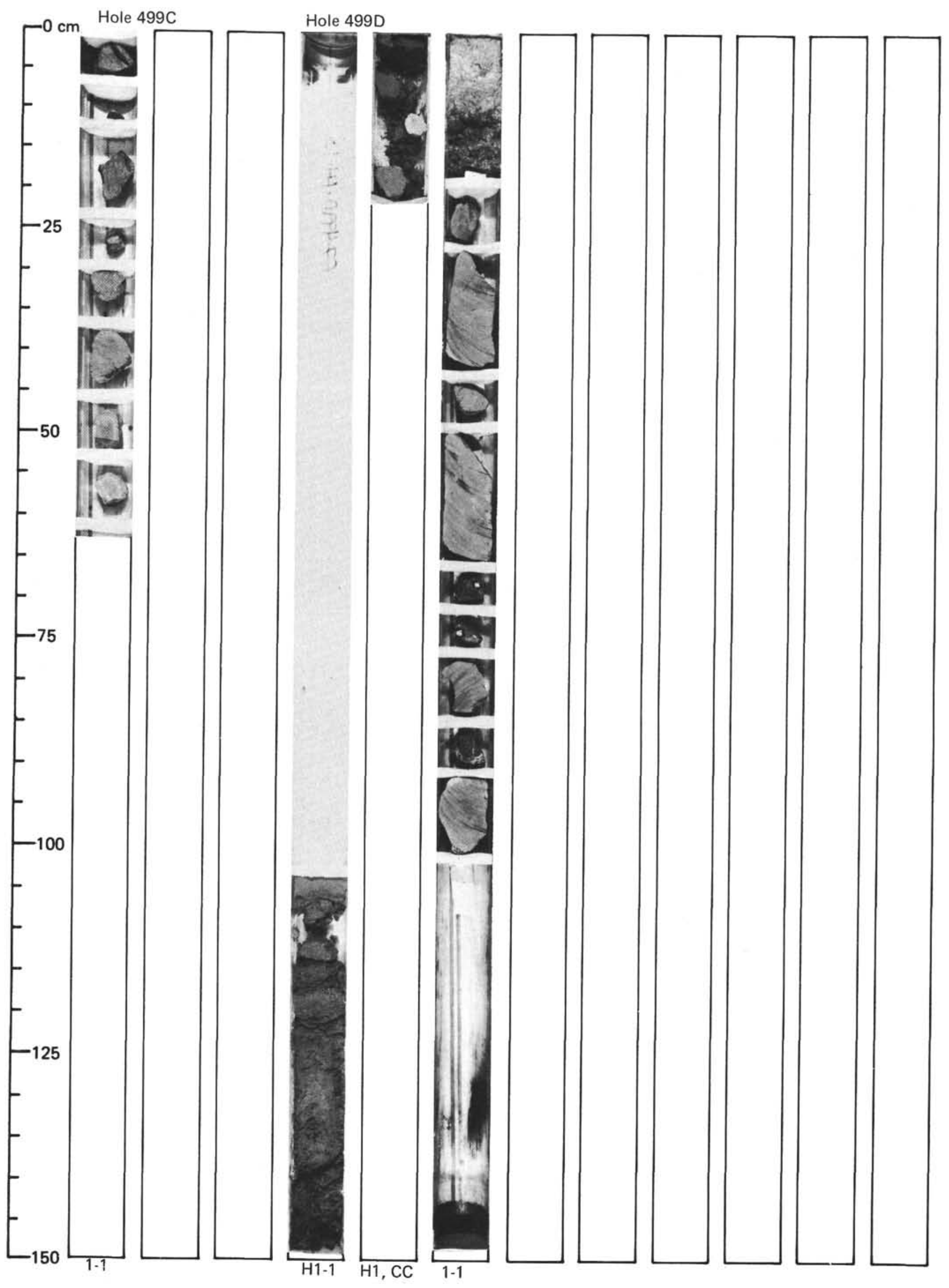

